\title{
Summer home range, habitat use, movements, and activity patterns of river otters (Lontra canadensis) in the Killbuck Watershed, northeastern Ohio
}

\author{
David A. Helon \\ West Virginia University
}

Follow this and additional works at: https://researchrepository.wvu.edu/etd

\author{
Recommended Citation \\ Helon, David A., "Summer home range, habitat use, movements, and activity patterns of river otters \\ (Lontra canadensis) in the Killbuck Watershed, northeastern Ohio" (2006). Graduate Theses, \\ Dissertations, and Problem Reports. 2358. \\ https://researchrepository.wvu.edu/etd/2358
}

This Thesis is protected by copyright and/or related rights. It has been brought to you by the The Research Repository @ WVU with permission from the rights-holder(s). You are free to use this Thesis in any way that is permitted by the copyright and related rights legislation that applies to your use. For other uses you must obtain permission from the rights-holder(s) directly, unless additional rights are indicated by a Creative Commons license in the record and/ or on the work itself. This Thesis has been accepted for inclusion in WVU Graduate Theses, Dissertations, and Problem Reports collection by an authorized administrator of The Research Repository @ WVU. For more information, please contact researchrepository@mail.wvu.edu. 
Summer Home Range, Habitat Use, Movements, and Activity Patterns of River Otters (Lontra canadensis) in the Killbuck Watershed, Northeastern Ohio

\author{
David A. Helon \\ Thesis submitted to the \\ Davis College of Agriculture, Forestry, and Consumer Sciences \\ at West Virginia University \\ in partial fulfillment of the requirements \\ for the degree of \\ Master of Science \\ in \\ Wildlife and Fisheries Resources
}

\author{
James T. Anderson, Ph.D, chair \\ Chris P. Dwyer, M.S. \\ John W. Edwards, Ph.D, co-chair
}

Morgantown, West Virginia

2006

Key Words: Activity patterns, habitat use, home range, Ohio Killbuck

Watershed, Lontra canadensis, radio-telemetry, river otters, wetlands

Copyright 2006 David A. Helon 


\title{
ABSTRACT \\ Summer Home Range, Habitat Use, Movements, and Activity Patterns of River Otters (Lontra canadensis) in the Killbuck Watershed, Northeastern Ohio
}

\author{
David A. Helon
}

River otters (Lontra canadensis), one of the most aquatic Mustelids, are important components of riparian systems and are an important fur-bearing species. Several studies evaluating post-release survival and movements have been conducted; however, there have been deficient long-term studies to determine the status of these river otter populations once established. During 2002 and 2003m 16 river otters ( 7 female, 9 male) were trapped and radio-tagged. Overall, mean female home range size was 802.4 ha and mean male home range size was 1,101.7 ha. Mean home range size was similar between genders in 2002, but was greater for males than females during 2003. I found differences in habitat use by river otters based on compositional analysis and a chi-square test.

Marsh habitat was used most frequently. Mean movement distance of female river otters $(\bar{x}=1.8 \mathrm{~km})$ was less than the mean movement distance of male river otters $(\bar{x}=5.2$ $\mathrm{km})$. River otters were most active between 2201 and 1000 and least active between 1001 and 1600 hours. This knowledge can be used in Ohio and other parts of the upper Midwest to aid in river otter management. 


\section{ACKNOWLEDGMENTS}

I thank The Ohio Division of Wildlife, FurBearers Unlimited, and the West Virginia University's Division of Forestry and Natural Resources for providing funding and logistical support for this project. Thank you to FurBearers Unlimited for the scholarship that they awarded me. I thank my committee members, Dr. James Anderson, Dr. John Edwards, and Chris Dwyer for their interest and guidance in this project. I also owe many thanks to the Killbuck Wildlife Management Area crew, Kevin Higgins, Dennis Solon, John Abele, and Erich Long. Right from the start they helped me get to know the study site and were there when I needed a laugh and some encouragement. I also would like to thank Dennis and John for helping me run river otter traps, and thank you guys for introducing me to "Twinks". Thank you to Karla Abele for taking me in like a son and feeding me continuously. I also thank the graduate students at WVU; you know who you are, for all the support and help getting through classes, field seasons and endless hours in the lab. Thanks goes to Joe Osbourne and Seth Lemley for all the GIS help you provided me with. I thank Herb Metzger for some additional funding that he provided. I also thank the USDA/APHIS/WS/NWRC Ohio Field Station for giving me time to finish this project and for statistical support and reviewing chapters.

I also thank those who supported me in other ways. First of all thank you to my wife, Sheri. Sheri supported me the whole time and put up with long field seasons a long way from home, and endless hours at the office and trapping, and a small, very small stipend. Thank you to my two daughters, Willow and Sage; they helped motivate me to get this done. A very special thanks goes to Chris Dwyer who helped in more ways that I can mention, THANK YOU. Thanks goes to Joe Barber who took the time to fly me 
whenever he had an opportunity and when I couldn't find river otters. Thank you to my whole family who supported and believed in me when I thought it would never get done. Thank you to the lunch crew, Bob Long, Joe Osbourne, Collins Balcombe, Harley Weaver, Scott Bosworth, and Andy Zadnik for all their support and laughter. I also thank Bob Long and Scott Bosworth who, at times, dragged me out into the fields hunting to help clear my head. 


\section{TABLE OF CONTENTS}

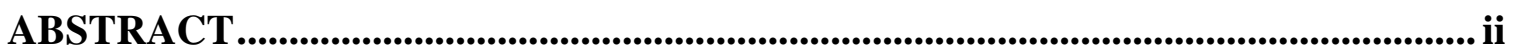

ACKNOWLEDGMENTS ................................................................................................. iii



LIST OF FIGURES

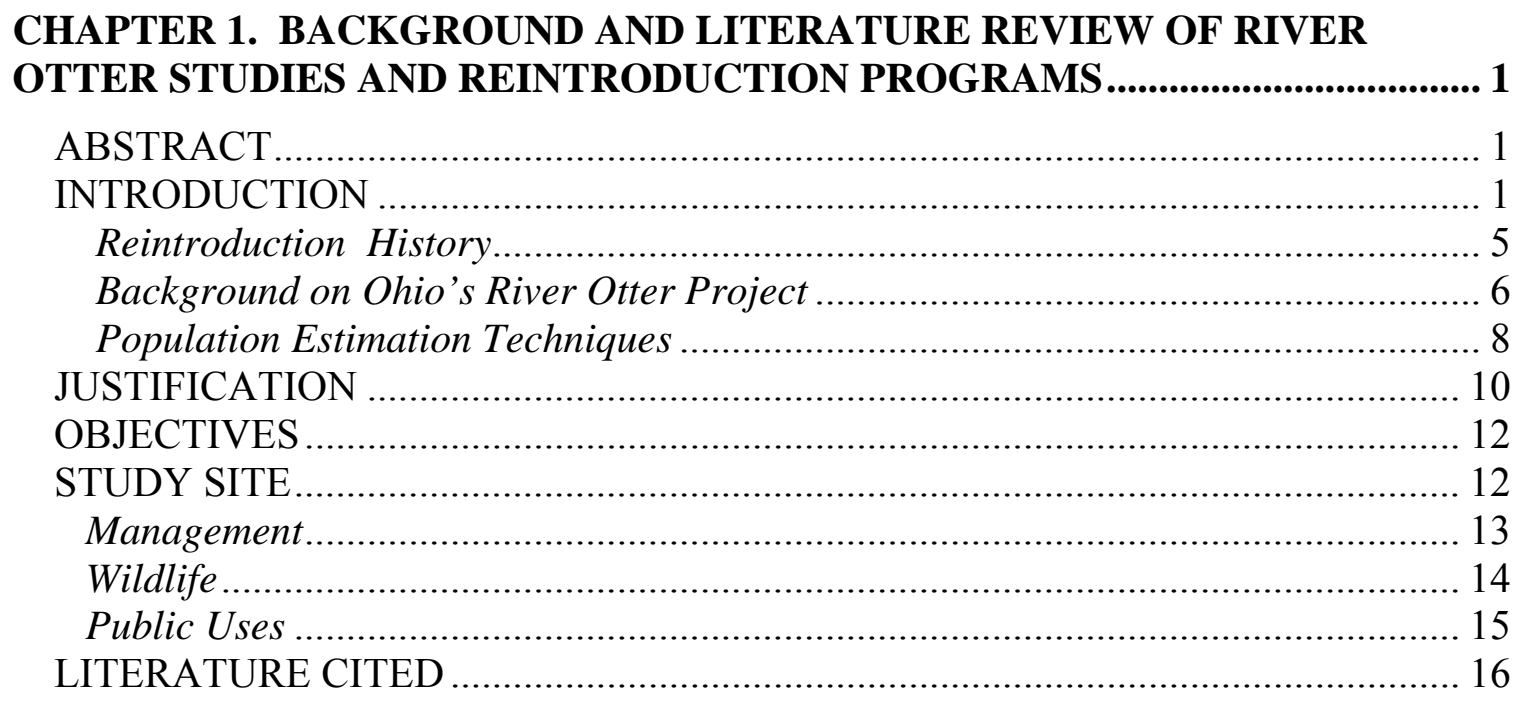

\section{CHAPTER 2. HOME RANGE SIZE AND HABITAT SELECTION BY RIVER}

OTTERS IN OHIO ............................................................................................... 37

ABSTRACT 


\section{CHAPTER 3. MOVEMENTS AND ACTIVITY PATTERNS OF RIVER OTTERS

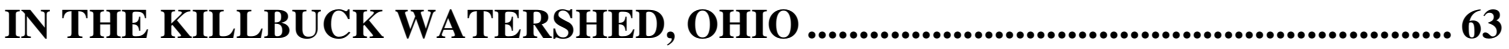



CHAPTER 4. CONCLUSIONS AND MANAGEMENT IMPLICATIONS............ 90

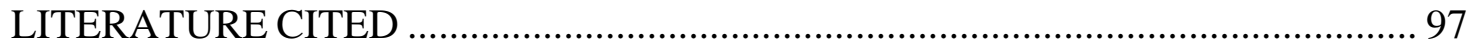

APPENDICES

\section{LIST OF TABLES}

\section{CHAPTER 1.}

Table 1. River otter reintroduction programs in North America...................................25

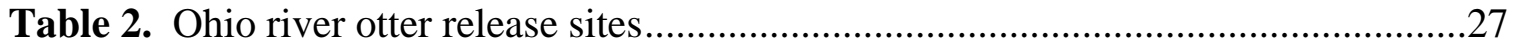

Table 3. Reported river otter harvest for the United States in 2000-2001 and 2001-2002

\section{CHAPTER 2.}

Table 1. Number of locations per river otter in the Killbuck Watershed, Ohio During 2002 and 2003

Table 2. Home ranges of river otters in the Killbuck Watershed, Ohio during 2002 and 2003.

Table 3. Confidence intervals of habitat use for river otters in the Killbuck Watershed, Ohio during 2002 and 2003 
Table 4. Number of locations (\% in parentheses) of radio-tagged river otters in each of 5 habitat types in the Killbuck Watershed, Ohio during 2002 and 2003.

Table 5. Home range estimates for river otters in other studies

\section{CHAPTER 3.}

Table 1. Dates of 24-hour tracking periods for river otters in the Killbuck Watershed, Ohio during 2002 and 2003

Table 2. Proportion of locations during which river otters were active or non-active during summer months (May-August) in the Killbuck Watershed, Ohio

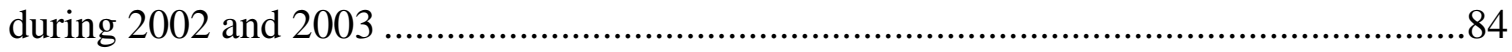

Table 3. Movement of river otter studies conducted across the USA............................85

\section{LIST OF FIGURES}

\section{CHAPTER 1.}

Figure 1. Location of the Killbuck Watershed, Ohio, where I conducted my river otter research in 2002 and 2003 .30

Figure 2. Riparian corridor along the Killbuck Creek at Killbuck Marsh

Wildlife Management Area, Ohio, 2003.

Figure 3. Flooding on the Killbuck Creek at Killbuck Marsh

Wildlife Management Area, Ohio, 2003.

Figure 4. Palustrine emergent marsh at Killbuck Marsh

Wildlife Management Area, Ohio, 2003.

Figure 5. Scrub-shrub wetland at Killbuck Marsh

Wildlife Management Area, Ohio, 2003

Figure 6. Flooded timber at Killbuck Marsh

Wildlife Management Area, Ohio, 2003..... .35

Figure 7. Wright's marsh located at the Killbuck Marsh

Wildlife Management Area, Ohio, 2003.

\section{CHAPTER 2.}

No Figures 


\section{CHAPTER 3.}

Figure 1. Location of the Killbuck Watershed, Ohio, where I conducted my river otter research in 2002 and 2003 .................................................................86

Figure 2. Traps used to catch river otters during our study. Victor 1.5 soft catch (top),

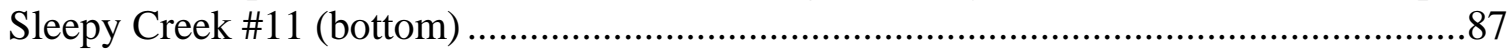

Figure 3. Immobilized river otter in transport box at veterinary facility .......................88

Figure 4. Number of locations (by hour) during which river otters were known to be active during (May-August) in the Killbuck Watershed during 2002 and 2003 ...............89 


\section{CHAPTER 1}

\section{BACKGROUND AND LITERATURE REVIEW OF RIVER OTTER STUDIES AND REINTRODUCTION PROGRAMS}

Abstract: River otters (Lontra canadensis) are important components of riparian systems and are an important fur-bearing species. River otters historically occupied one of the largest geographic ranges of all North American mammals. Populations of river otters were drastically reduced during the $19^{\text {th }}$ century due to factors such as unregulated trapping, water pollution, and habitat degradation. Since the 1970s many state agencies including Ohio began reintroduction programs with the majority of river otters originating from Louisiana. Several studies evaluating post-release survival and movements have been conducted; however, there have been deficient long-term studies to determine the status of these river otter populations once established. Additional studies need to be conducted to evaluate river otter populations to help improve the ability to scientifically manage river otters.

Key words: Lontra canadensis, radio-telemetry, reintroduction, river otters, wetlands

\section{INTRODUCTION}

Prior to the 1900s, river otters (Lontra canadensis) were common in Ohio as well as many other states and Canadian provinces. Due to unregulated trapping, water pollution, and destruction of river otter habitat, populations suffered heavy declines by the early 1900s (Toweill and Tabor 1982, Melquist and Dronkert 1987, Lariviere and Walton 1998, Raesly 2001, Dwyer 2003). Prior to European settlement, river otters were established throughout most of the major drainages in North America (Hall 1981, Schwartz and Schwartz 1995, Whitaker and Hamilton 1998, Raesly 2001). River otter

This chapter written in the style of The Journal of Wildlife Management. 
densities were greatest in coastal marshes, the Great Lakes Region, and in glaciated areas of the Northeast (Nilsson 1980, Toweill and Tabor 1982, Melquist and Dronkert 1987). Before river otter reintroduction programs started, river otters occurred in northern Alaska, from eastern Newfoundland to the Aleutian Islands, and into the southern states of Florida and Texas; but remained absent in some of the arid southwest states (Chapman and Feldhamer 1982, Melquist and Hornocker 1983, Melquist and Dronkert 1987). Due to the high prices of fur in the 1970s, trapping pressure increased causing harvest rates to escalate (Morrison et al. 1981). Concurrently there was increased concern over furbearer harvest levels (Chapman and Pursley 1980). In response, the biological, economic, and sociological aspects of furbearers and harvesting techniques were evaluated and interest in furbearer management escalated (Chapman and Pursley 1980). This awareness prompted state and federal agencies to restore certain furbearer species, setting more stringent harvesting guidelines, and furbearer research.

River otters can adapt to a wide range of aquatic habitats, but are most common along coastal areas with abundant food resources, as well as extensive unpolluted wetlands, streams, and backwater sloughs with minimal human impacts (Tabor and Wight 1977, Mowbray et al. 1979, Bluett and Hubert, Jr. 1995). River otters are less abundant in areas with heavy human impact, polluted waterways, and mountain streams with low food availability (Toweill and Tabor 1982). Newman and Griffin (1994) found that river otters in Massachusetts used a wide variety of wetlands and deepwater systems, such as shallow palustrine scrub-shrub and forested wetlands, deep lacustrine limnetic zones, and lower perennial riverine habitats. Critical factors that influence habitat selection are food availability, stable water supplies (Melquist and Hornocker 1983), and 
adequate cover (Wayre 1979). Areas that support beaver (Castor canadensis)

populations also can be important because they create suitable habitat for river otters (Choromanski and Fritzell 1982, Larsen 1983, Melquist and Hornocker 1983, Anderson and Woolf 1984, Woolington 1984, Melquist and Dronkert 1987, Polechla 1987, Bluett and Hubert 1995). Beck (1993) mentions that dense herbaceous vegetation like sedges (Carex spp.) and cattails (Typha spp.) are important cover components. River otters often utilize tree roots, dense shrubs, tall grasses, fallen trees, and logjams as foraging and temporary resting sites (Melquist and Hornocker 1983, Melquist and Dronkert 1987, Beck 1993). River otters tend to use natural formations, man-made structures, and dens built by other animals (i.e., beavers and muskrats [Ondatra zibethicus]) for denning and resting sites rather than excavating structures themselves (Melquist and Hornocker 1983).

Terrain, topography, habitat, and food resources are important variables that determine home range size. Melquist and Hornocker (1983) reported river otter home ranges that were linear, and generally followed water systems in the mountains of westcentral Idaho. River otters that exist in coastal marshes and inland systems often have a home range that resembles a polygon (Foy 1984, Melquist and Dronkert 1987). Males generally have a larger home range than females (Reid et al. 1994) and adults will have larger home ranges than juveniles (Ellis 1964, Melquist and Dronkert 1987). Lactating females have the most restricted home range sizes (Polechla 1990).

River otter densities are extremely variable. Food availability, habitat type, and time of year all impact river otter densities. A study conducted on coastal marshes of Texas, USA determined densities to be 1 river otter per 71-106 ha (Foy 1984), while a study in Alberta Canada showed densities to be 1 river otter per 10-17 km of waterways 
(Reid et al. 1994). River otter densities in Missouri ranged from 1 river otter $/ 4 \mathrm{~km}$ of waterway at Swan Lake National Wildlife Refuge to 1 river otter $/ 8 \mathrm{~km}$ of waterway at Lamine River Wildlife Area (Erickson et al. 1984). River otters occupying Prince William Sound, Alaska had average densities of 0.28 to 0.80 river otters $/ \mathrm{km}$ of coastline (Testa et al. 1994).

River otters spend the majority of their time in water and feed primarily on fish, but also consume crustaceans, insects, other invertebrates, amphibians, birds, mammals, and turtles (Liers 1951, Toweill and Tabor 1982). A study in Wisconsin showed that river otters fed mostly on fish but also consumed large quantities of crayfish and frogs (Beckel 1990). Melquist and Hornocker (1983) observed river otters feeding intensively on spawning salmonids during the fall. River otters typically feed on prey $<15 \mathrm{~cm}$ long while remaining in the water, and surface on the ice or shore to consume larger prey items (Beckel 1990).

River otters often forage along undercut banks, logjams, shorelines, and other areas that offer cover for a variety of prey species (Melquist and Hornocker 1983). River otters have been observed foraging and hunting in pairs; however, Beckel (1990) observed that river otters hunting in pairs did not dive together, share food, or fight over food. She also concluded that there was no apparent coordination of hunting strategies and they usually stayed a couple of meters apart. River otter's surface at locations referred to as "pull outs" or "haul outs", where they commonly roll, groom, defecate, and scent mark territories (Melquist and Hornocker 1983). River otter scats are commonly found on large logs, rocks, logjams, sandbars, and other objects that project from the water or the bank that commonly mark territories (Melquist and Hornocker 1983). 
Although existing surveys provide a general indication of where river otters are known to occur in Ohio, there is little information on habitat use, home range, and movement patterns of river otters. Movement data are important and useful for the management of many species of wildlife. Sanderson (1966) describes mammal movements as a combination of activity, home range, migration, immigration, and emigration, associated with behavior and territory. Many variables affect the home range of animals but the most crucial is the type of habitat, which influences prey availability and cover. Melquist and Hornocker (1983) state that objective data are needed concerning river otter ecology, including factors that determine density, distribution, and survival, so that sound management policies can be established.

\section{Reintroduction History}

River otters have been reintroduced to many Canadian provinces and U.S. states (Table 1), especially in the Midwest where they were extirpated or survived in low populations. Reasons for reintroductions included the reestablishment of a native species, the potential for harvest, aesthetics, cultural significance (Raesly 2001), habitat availability, predation value, high fur value, public relations, and to preserve locally rare or threatened species (Berg 1982). Griffith et al. (1989) indicates that reintroductions and translocations of river otters are successful if a population is successful (increasing, reproducing) near the release site. However, documentation of reproduction is a difficult task due to low population densities, delayed reproduction, habitats that are difficult for humans to access (Reid et al. 1987, Erickson and Hamilton 1988, Ralls 1990, Hamilton 1995), and the secretive lifestyle of river otters. River otters are usually obtained for reintroduction programs through private trappers or state wildlife agencies, with a 
majority of river otters coming from Louisiana as was the case of the river otter reintroduction program in Ohio. Gene flow is often of concern with reestablishing river otter populations because river otter home ranges are limited in many areas due to human activity and untraversable terrain (Serfass et al. 1998). In the late 1970s through the early 1990s several states began to conduct feasibility studies to reintroduce river otters into their native range (i.e., West Virginia [Bottoroff et al. 1976], Ohio [McDonald 1989], Indiana [Johnson and Madej 1994], and Illinois [Bluett and Hubert 1995]. The state of Ohio started a feasibility study and river otter reintroduction program in 1986 (McDonald 1989). Many other states have participated in river otter reintroduction programs, including: Arizona (Britt et al. 1982), Iowa, Illinois (Anderson and Woolf 1984), Indiana (Johnson and Berkley 1999), Maryland (Serfass et al. 1983), Minnesota (Berg 1982), New York, Pennsylvania, Oklahoma (Serfass et al. 1986), Colorado (Mack 1985), Tennessee (Griess 1987), West Virginia (Bottoroff et al. 1976), Kansas, Kentucky, Missouri, Nebraska, North Carolina, South Dakota, Utah, and Virginia (Melquist and Dronkert 1987, Bluett and Hubert 1995, Raesly 2001).

\section{Background on Ohio's river otter project}

River otters were common in Ohio prior to the mid 1800s when unregulated trapping, habitat destruction, water pollution, and other factors caused river otter populations to decline severely (Nilsson 1980, Raesly 2001, Dwyer 2003). In 1986 and 1987, the Ohio Division of Wildlife conducted a feasibility study to reintroduce river otters (McDonald 1989). Based on the results of that study, a reintroduction program was implemented from 1988 through 1993. Criteria for Ohio release sites were waterways having fairly long $(>80 \mathrm{~km})$, low gradient streams with alternating riffle-pool structures. Waterways 
were also required to be wet-year round, have high water quality, and a high stream meander index with abundant stream structure including: fallen trees, logjams, exposed root cavities, beaver dams, and/or debris piles (Tumlinson and Shalaway 1985, Missouri Department of Conservation 1986). With the aid of cooperating trappers from Louisiana and Arkansas, 123 (76 male, 47 female) river otters were released in 4 separate watersheds throughout eastern Ohio (Grand River, Trumbull County $n=48$, Killbuck Creek, Wayne/Holmes County $n=24$, Stillwater Creek, Harrison County $n=25$, and Little Muskingum River, Monroe County $n=26$ ) (Dwyer 2003); (Table 2). River otters were obtained through private trappers in Arkansas $(n=8)$ and Louisiana $(n=115)$ (Dwyer 2003). Survival, home range, habitat use, movements, and feeding habits of 21 river otters were studied at the Grand River Wildlife Management Area (McDonald 1989).

Following the reintroduction the Ohio Division of Wildlife has been conducting several monitoring programs to evaluate the success of the reintroduction program, as well as the status of river otter populations throughout the state. Monitoring programs used to evaluate river otters in the state are: 1) river otter observation reporting system;2) bridge crossing survey; 3) population modeling; 4) aerial snow track surveys; 5) bowhunter surveys; 6) evidence of reproduction via necropsies; and 7) telemetry study to determine annual survival rates and reproduction (C. Dwyer, Ohio Division of Wildlife, personal communication 2001). The river otter population in Ohio has continued to expand its range, and population models suggest there should be over 4,500 river otters in Ohio in 2004. The model uses conservative parameters for survival and reproduction (Erickson et al. 1984) because such data for Ohio river otters are lacking (Dwyer 2003). 
River otters were considered to be state endangered until 2002, at which time, the strength of evidence based on surveys and research indicated river otters were becoming more abundant.

Since the release program ended in Ohio in 1993, monitoring the distribution and range expansion of river otters has consisted primarily of observational reports from Ohio Division of Wildlife personnel and the public. However, river otter observation reporting by the public typically declines as a species becomes more abundant, which reduces observations that may be important in certain watersheds or waterways (Bluett et al. 1999, Johnson 2001). Moreover, river otters are difficult to observe due to their secretive nature (Swimley et al. 1998); therefore, efforts to determine the status and level of watersheds occupied by river otters has resulted in several new programs, including an extensive river otter bridge survey (Dwyer 2003).

\section{Population Estimation Techniques}

Many strategies have been developed and used to determine presence or absence of river otters and to estimate their populations. An amalgamation of techniques have been used to estimate populations such as capture and telemetry data, visual observations of marked and unmarked animals, snow tracks, observation reports, fur harvest data from trappers, aerial surveys, scent station surveys, and the presence of sign (Linhart and Knowlton 1975, Melquist and Hornocker 1979, Dwyer 2003). Although there is no simple approach for censusing river otters, presence and distribution can be easily obtained (Melquist and Hornocker 1979). Melquist and Hornocker (1983) determined that river otter sign observed on surveys correlates with distribution but not with 
population densities. An increase in sign during early spring relates to the variations in habitats and behavior compared to changes in density (Foy 1984).

Surveys conducted using snow tracks as a population estimation technique work well, although they require many hours and adequate snow cover (Reid et al. 1987). Limiting factors include observer error, timing and amount of snow cover which could over-or under-estimate a population (Reid et al. 1987). Observational reports can be insufficient if river otters are nocturnal or occur away from human activity, or if reporting rates diminish with an increase in observations. Aerial surveys are costly and require adequate amounts of snow to be effective. Telemetry studies also are expensive, but allow the investigators to study animals with little disturbance. Monitoring relative abundance of river otters using scent stations is labor intensive and may provide low resolution (Robson and Humphrey 1985). Accurate fur harvest data can be obtained through mandatory river otter pelt-tagging programs, although data also can be skewed by river otter pelt value, beaver pelt value, trapping regulations and factors affecting trapper participation and compliance (C. Dwyer, Ohio Division of Wildlife, personal communication 2002).

Age determination can be done by cementum annuli sectioning (Dimmick and Pelton 1996). Canine teeth are considered most reliable when performing annuli counts for the purpose of aging (Stephenson 1977). This can be for statewide, regional, or watershed level determinations (C. Dwyer, Ohio Division of Wildlife, personal communication 2002). The data also can be used for validation of age ratios in population models. 
The use of radio telemetry equipment to track animals is advantageous when animal movement and activity patterns are difficult to observe using visual methods or mark-recapture techniques (Samuel and Fuller 1996). Radio transmitters are surgically implanted in river otters to minimize disruption of the animal's normal behavior and movements (Melquist and Hornocker 1979, Samuel and Fuller 1996). Veterinary medical procedures are necessary for transmitter implants, including aseptic or antiseptic conditions, sedation or anesthesia, antibiotics, and monitoring post surgery recovery (Samuel and Fuller 1996). Proper placement of intra peritoneal implants are crucial to ensure the transmitter does not hamper movement and body functions (Williams and Siniff 1983). Radio tracking improves the ability to recognize individual animals, obtain accurate locations, and determine the extent of the range that is being used by each individual (Sanderson 1966). Mercury switches used as motion detectors may be incorporated into transmitters for use in detecting certain behavior, such as prolonged inactivity due to mortality (Kenward 1987, Samuel and Fuller 1996). River otter transmitters typically have a life expectancy of 24 to 36 months and weigh 100-110 g.

\section{Justification}

River otters are important components of riparian systems. In many areas they are considered the top aquatic predator keeping some prey species, such as carp (Cyprinus carpio), from becoming overabundant. They also have been labeled as a sentinel species, sensitive to pollutants, and an indicator of environmental contaminants (Bowyer et al. 2003). River otters are important fur-bearing species, and their pelts are often considered to be the most beautiful and durable of all North American furs (Schwartz and Schwartz 1995), with harvests reaching 50,000 annually in the late 1970s 
and early 1980s (Deems and Pursley 1983). Bottorff et al. (1976) and a USFWS unpublished report indicate that several states (Louisiana, Michigan, Minnesota, and Wisconsin) were reporting annual harvests of $>1,000$ river otters during the 1970 s (Table 3). In the United States, a total of 24,695 and 22,546 river otters were harvested during the 2001-2002 and 2000-2001 trapping seasons, respectively, with average prices of \$105-\$121 during the 2003 season (Brian Macmillan, North American Fur Auctions, personal communication 2004)(Table 3). However, river otters declined drastically in North America in the early 1900s due to habitat loss, exploitation, and environmental contamination (Berg 1982). River otters were considered to be extirpated in many states during this period, including Ohio.

River otters have made a dramatic comeback due to the many reintroduction programs throughout North America river otters are one of the larger Mustelids and are considered top predators that are highly mobile. They exploit specialized semi-aquatic niches in addition to occurring at low population densities (Stephenson 1977, Hall 1981, Melquist and Hornocker 1983). Their role as a top predator in aquatic systems and their tendency to bioaccumulate pollutants such as organochlorines and heavy metals (Stone and Sheean-Stone 1992, Bowyer et al. 2003) makes them an important species to study. Several post reintroduction studies have been conducted to determine survival and movements of river otters; see review by (Raesly 2001); however, there has been a lack of long-term studies or any systematic effort to determine the status of these reintroduced river otters (Raesly 2001). Continued research on river otters is important to determine how these populations change over time and if habitat is still available for them to expand their ranges. In addition, such information would be needed to prevent over-population 
that could create conflict with pond owners, fish hatcheries, and anglers. In Missouri, sport fisherman contend that river otters were impacting centrarchid fish populations (Roberts 2003).

\section{Objectives}

Current monitoring programs indicate that more research is needed to accurately manage river otters in Ohio. The objectives of this study were to:

(1) Determine home range of female and male river otters in the Killbuck Watershed in northeastern Ohio;

(2) Evaluate habitat use of both female and male river otters in the Killbuck Watershed; and

(3) Determine movements and activity patterns of female and male river otters during $24 \mathrm{hr}$ periods in the Killbuck Watershed.

All information obtained during this study will be used to shape population models of river otters in Ohio. These population models will aid in future management plans for the state of Ohio and provide a better understanding of this species.

\section{Study Site}

This project was conducted throughout the Killbuck Watershed located in northeastern Ohio (Fig. 1). Killbuck Creek runs through 3 counties (Wayne, Holmes and Coshocton), with a watershed of 157,730 ha and a channel length of $132 \mathrm{~km}$. The upper end of Killbuck Creek has a gentle slope of $39.1 \mathrm{~cm}$ of fall $/ \mathrm{km}$ for the upper $3 \mathrm{~km}$ of the creek. In the southern end the topography gets rougher and steeper along with the tributaries that drain into Killbuck Creek (Beck 1993). Good riparian corridors exist along portions of Killbuck Creek, however; other areas are dredged frequently causing 
this system to be highly prone to flooding, especially in early spring due to snowmelt. Approximately $56 \%$ of this area consists of palustrine emergent, palustrine scrub-shrub, and palustrine forested wetlands (Cowardin et al. 1979) that are flooded during some portion of the year.

The climate is hot and humid in summer (average $=21^{\circ} \mathrm{C}$ ) and moderately cold throughout winter (average $\left.=-2^{\circ} \mathrm{C}\right)$ with an average first fall freeze date $\left(0^{\circ} \mathrm{C}\right)$ occurring 6 October (National Oceanic and Atmospheric Administration 1982).

Precipitation averages $91.4 \mathrm{~cm}$ annually, with a monthly average of $7.6 \mathrm{~cm}$. February is the driest month $(4.8 \mathrm{~cm})$ and July $(10.7 \mathrm{~cm})$ is the wettest month (National Oceanic and Atmospheric Administration 1982, Beck 1993). Killbuck Creek can be influenced heavily by precipitation, with minimum daily flow rates ranging from $1.7 \mathrm{~m}^{3} / \mathrm{s}$ to $94.3 \mathrm{~m}^{3} / \mathrm{s}$, and a mean of $22.1 \mathrm{~m}^{3} / \mathrm{s}$ (United States Geological Survey 2002). The area is in the Mahoning-Canfield-Rittman-Chili soils region, part of the Eastern Ohio Till Plain, where glacial deposits range from coarse-textured to fine-textured, although coarsertextured and well drained soils occur more frequently in the southern portion of this region (Ohio Department of Natural Resources 1990).

\section{Management}

The Killbuck Wildlife Management Area (WMA) encompasses 2,234 ha of the watershed and is located in Wayne and Holmes Counties. This area is located in a Ushaped glacial outwash valley with elevations of $256 \mathrm{~m}$ at the floor of Killbuck Creek to nearly $305 \mathrm{~m}$ on hillsides that parallel the valley floor. The Ohio Division of Wildlife acquired the Killbuck WMA in 1969, which is Ohio’s largest remaining wetland complex outside of the Lake Erie Marsh region. Establishment of food patches for general 
wildlife use, maintenance, and protection of the existing woodlands, establishment of regular crop rotations, improvement of open fields for wildlife nesting by controlled burning and selective spraying, are all part of the current wildlife management plan. There are several wetland areas adjacent to Killbuck Creek that are equipped with dikes and water control structures, such as Wright's Marsh, which encompasses 141.6 ha (Fig. 7). Several other marshes in the area are void of any type of water management structures or management.

\section{Wildlife}

Fish species that inhabit Killbuck Creek are northern pike (Esox lucius), common carp, suckers (Catostomidae spp.), bullheads (Ameiurus spp.), and Centrarchid species. Mammals that occupy this area include white-tailed deer (Odocoileus virginianus), eastern cottontail rabbit (Sylvilagus floridanus), raccoon (Procyon lotor), woodchuck (Marmota monax), river otter, beaver, muskrat, eastern fox squirrel (Sciurus niger), and most of Ohio's other furbearers. Beaver populations during the last several years have increased rapidly, which in turn creates suitable habitat for a diversity of wildlife such as furbearers, waterfowl, fish, frogs, turtles, and songbird species. Management activities provide adequate conditions for a variety of upland birds such as eastern wild turkey (Meleagris gallopavo), ring-necked pheasant (Phasianus colchicus), and bobwhite quail (Colinus virginianus). Wood ducks (Aix sponsa), Canada geese (Branta canadensis), mallard (Anas platyrhynchos), blue-winged teal (A. discors), and black ducks (A. rubripes) are common during winter months. The area is important for migrating waterfowl and songbirds. Birds such as Canada geese, wood ducks, barn owl (Tyto alba), screech owl (Otus asio), American kestrel (Falco sparverius), eastern bluebird (Sialia 
sialis), and prothonotary warbler (Protonotaria citrea), use nest boxes distributed throughout the wildlife management area (Ohio Division of Wildlife 1999). Sandhill cranes (Grus canadensis), trumpeter swans (Cygnus buccinator), and bald eagles (Haliaeetus leucocephalus) also nest on the wildlife area.

\section{Public Uses}

Killbuck Wildlife Management Area is open to the public year-round, with hunting, trapping, and fishing being the most popular activities. Other popular activities include canoeing, birding, and hiking. There are numerous county and township roads and parking areas scattered throughout the wildlife management area for public access. 


\section{LITERATURE CITED}

Anderson, E. A., and A. Woolf. 1984. River otter (Lutra canadensis) habitat utilization in northwestern Illinois. Final report submitted to Endangered Species Program, Illinois Dept. of Conservation, Springfield, Illinois, USA.

Berg, W. E. 1982. Reintroduction of fisher, pine marten, and river otter. Pages 159-174 in G.C. Sanderson, editor. Midwest furbearer management. North Central and Central Plains Sections of the Wildlife Society, Wichita, Kansas, USA.

Beck, T. D. I. 1993. Development of river otter reintroduction procedures. Colorado Division of Wildlife, Research Review 2, Denver, Colorado, USA.

Beckel, A. L. 1990. Foraging success rates on North American river otters, Lutra canadensis, hunting alone and hunting in pairs. The Canadian Field-Naturalist, 104:586-588.

Bluett, R., and G. Hubert Jr. 1995. Background. Pages 1-22 in R. Bluett, editor. Illinois river otter recovery plan. Illinois Department of Natural Resources, Springfield, Illinois, USA.

, E. A. Anderson, G. F. Hubert, Jr., G. W. Kruse, and S. E. Lauzon. 1999.

Reintroduction and status of the river otter (Lutra canadensis) in Illinois.

Transactions of the Illinois academy of science 92:69-78.

Bottoroff, J. A., R. A. Wigal, D. Purlsey, and J. I. Cromer. 1976. The feasibility of river otter reintroduction in West Virginia. Special Report, West Virginia Deptartment of Natural Resources, Division of Wildlife, Charleston, West Virginia, USA. 
Bowyer, R. T., G. M. Blundell, M. Ben-David, S. C. Jewett, T. A. Dean, and L. K. Duffy. 2003. Effects of the Exxon Valdez oil spill on river otters: injury and recovery of a sentinel species. Wildlife Monographs 153:1-53.

Britt, T. L., R. L. Glinki, and J. S. Phelps. 1982. River otter stocking. Arizona Federal Aid Project, W-53-R-32, WP6-J4, Arizona Game and Fish Department, Phoenix, Arizona, USA.

Chapman, J. A., and D. Pursley, editor. 1980. Worldwide furbearer conference proceedings. Frostburg, Maryland, USA.

, and G. A. Feldhamer, editors. 1982. Wild mammals of North America. The Johns Hopkins University Press, Baltimore, Maryland, USA.

Choromanski, J. F., and E. K. Fritzell. 1982. Status of the river otter (Lutra canadensis) in Missouri. Transactions of the Missouri Academy of Sciences 16:43-48.

Cowardin, L. M., V. Carter, and E. T. LaRoe. 1979. Classification of wetlands and deepwater habitats of the United States. U.S. Fish and Wildlife Service, Report FWS/OBS-79/31.

Deems, E. F., Jr., and D. Pursley, editors. 1983. North American furbearers: a contemporary reference. International Association of Fish and Wildlife Agencies, Maryland Department of Natural Resources. Annapolis, Maryland, USA.

Dimmick, R. W., and M. R. Pelton. 1996. Criteria of sex and age. Pages 169-214 in T.A. Bookhout, editors. Research and management techniques for wildlife and habitats. Fifth edition, The Wildlife Society, Bethesda, Maryland, USA. 
Dwyer, C. P. 2003. Population assessment and distribution of river otters following their reintroduction into Ohio. Ohio Division of Wildlife. 2003 Wildlife Research Report. Columbus, Ohio, USA.

Ellis, R. J. 1964. Tracking raccoons by radio. Journal of Wildlife Management 28:363368.

Erickson, D. W., C. R. McCullough, and W. E. Porath. 1984. River otter investigations in Missouri. Missouri Department of Conservation. Pittman-Robertson Project W-13-R-38, Final Report 47. Columbia, Missouri, USA. , and D. A. Hamilton. 1988. Approaches to river otter restoration in Missouri. Transactions of the $53^{\text {rd }}$ North American Wildlife and Natural Resource Conference 53:404-413.

Foy, M. K. 1984. Seasonal movement, home range, and habitat use of river otter in southeastern Texas. Thesis, Texas A\&M University, College Station, Texas, USA.

Griess, J. M. 1987. River otter reintroduction in Great Smokey Mountains National Park. Thesis, University of Tennessee, Knoxville, Tennessee, USA.

Griffith, B., J. M. Scott, J. W. Carpenter, and C. Reed. 1989. Translocation as a species conservation tool: status and strategy. Science 245:477-480.

Hall, E. R. 1981. The mammals of North America. Second edition. John Wiley and Sons, New York, New York, USA. 
Hamilton, D. A. 1995. The status of river otters and their habitat in Missouri in 1995 and rationale and procedures for an experimental trapping season. Missouri Department of Conservation. Columbia, Missouri, USA.

Johnson, S. A., and R. F. Madej. 1994. Reintroduction of the river otter in Indiana: feasibility study. Bloomington, Indiana, USA.

, and K. A. Berkley. 1999. Restoring river otters in Indiana. Wildlife Society Bulletin 27:419-427. . 2001. Indiana river otter reintroduction program: 2000-2001. Bloomington, Indiana, USA.

Kenward, R. E. 1987. Wildlife radio tagging. Academic Press, London, United Kingdom.

Lariviere, S., and L. R. Walton. 1998. Mammalian species account: Lontra canadensis. American Society of Mammalogists 587:1-8.

Larsen, D. N. 1983. Habitats, movements and foods of river otters in coastal southeastern Alaska. Thesis, University of Alaska, Fairbanks, Alaska, USA.

Liers, E. M. 1951. Notes on the river otter (Lutra canadensis). Journal of Mammalogy $32: 19$.

Linhart, S. B., and F. F. Knowlton. 1975. Determining the relative abundance of coyotes by scent station lines. Wildlife Society Bulletin 3:119-124.

Mack, C. M. 1985. River otter restoration in Grand County, Colorado. Thesis, Colorado State University, Fort Collins, Colorado, USA. 
McDonald, K. P. 1989. Survival, home range, movements, habitat use, and feeding habits of reintroduced river otters in Ohio. Thesis, Ohio State University, Columbus, Ohio, USA.

Melquist, W. E., and M. G. Hornocker. 1979. Methods and techniques for studying and censusing river otter populations. Forest, Wildlife, and Range Experiment Station, Technical Report 8. University of Idaho, Moscow, Idaho, USA. , and M. G. Hornocker. 1983. Ecology of river otters in west central Idaho. Wildlife Monographs 83:1-60. , and A. E. Dronkert. 1987. River otter. Pages 625-641 in M. Novak, J. A. Baker, M. E. Obbard, and B. Malloch, editors. Wild furbearer management and conservation in North America. Ontario Trappers Association, North Bay, Ontario, Canada.

Missouri Department of Conservation. 1986. Species management plan for the river otter in Missouri. Columbia, Missouri, USA.

Morrison, D. W., R. M. Edmunds, G. Linscombe, and J. W. Goertz. 1981. Evaluation of specific scent station variables in northcentral Louisiana. Procedings of the Annual Conference of the Southeast Association of Fish and Wildlife Agencies $35: 281-291$

Mowbray, E. E., D. Pursley, and J. A. Chapman. 1979. The status, population characteristics and harvest of the river otter in Maryland. Maryland Wildlife Administration, Publication Wildlife Ecology 2. Annapolis, Maryland, USA. 
National Oceanic and Atmospheric Administration. 1982. Monthly normals of temperature, precipitation, and heating and cooling degree days, Ohio. Climatology of the United States, Number 81. Columbus, Ohio, USA.

Newman, D. G., and C. R. Griffin. 1994. Wetland use by river otters in Massachusetts. Journal of Wildlife Management 58:18-23.

Nilsson, G. 1980. River otter research workshop. Florida State Museum. Gainesville, Florida, USA.

Ohio Department of Natural Resources. 1990. Soil regions of Ohio. Columbus, Ohio, USA.

Ohio Division of Wildlife. 1999. Killbuck marsh wildlife area. Publication 233(R901). Columbus, Ohio, USA.

Polechla, P.J. 1987. Status of the river otter (Lutra canadensis) in Arkansas with special reference to reproductive biology. Dissertation, University of Arkansas, Fayetteville, Arkansas, USA. . 1990. Action plan for North American river otters. Pages 74-79 in FosterTurley et al. editors. Otters: an action plan for their conservation. International Union for Conservation of Nature and Natural Resources, Kelvin Press, Inc., Broadview, Illinois, USA.

Raesly, E. J. 2001. Progress and status of river otter reintroduction projects in the United States. Wildlife Society Bulletin 29:856-862.

Ralls, K. 1990. Pages 20-21 in P. Foster-Turley, S. MacDonald, and C. Mason, editors. Otters: an action plan for their conservation. Kelvyn, Broadview, Illinois, USA. 
Reid, D. G., M. B. Bayer, T. E. Code, and B. McLean. 1987. A possible method for estimating river otter, Lutra canadensis, populations using snow tracks. Canadian Field-Naturalist 101:576-580.

Roberts, N. M. 2003. River otter food habits in the Missouri Ozarks. Thesis, University of Missouri, Columbia, Missouri, USA.

, T. E. Code, and S. M. Herrero. 1994. Spacing, movements, and habitat selection of the river otter in boreal Alberta. Canadian Journal of Zoology $72: 1314-1324$

Robson, M. S., and S. R. Humphrey. 1985. Inefficacy of scent-stations for monitoring river otter populations. Wildlife Society Bulletin 13:558-561.

Samuel, M. D., and M. R. Fuller. 1996. Wildlife radiotelemetry. Pages 370-418 in T.A. Bookhout, editor. Research and management techniques for wildlife and habitats. Fifth edition. The Wildlife Society, Bethesda, Maryland, USA.

Sanderson, G. C. 1966. The study of mammal movements-A review. Journal of Wildlife Management 30:215-235.

Schwartz, C. W., and E. R. Schwartz. 1995. The wild mammals of Missouri. Revised edition. University of Missouri Press, Columbia, Missouri, USA.

Serfass, T. L., M. S. Randall, L. Peper, M. T. Whary, and R. P. Brooks. 1983. River otter (Lutra canadensis) reintroduction in Pennsylvania: prerelease care and clinical evaluation. Journal of Zoo and Wildlife Medicine 24:28-40.

, L. M. Rymon, and J. D. Hassinger. 1986. Development and progress of Pennsylvania's river otter reintroduction program. Pages 322-343 in S.K. 
Majundar, F.J. Brenner, and A.F. Rhoads, editors. Endangered and threatened species programs in Pennsylvania and other states: causes, issues, and management. Pennsylvania Academy of Sciences, Harrisburg, Pennsylvania, USA.

, R. P. Brooks, J. M. Novak, P. E. Johns, and O. E. Rhodes, Jr. 1998. Genetic variation among populations of river otters in North America: considerations for reintroduction projects. Journal of Mammalogy 79:736-746.

Stephenson, A. B. 1977. Age determination and morphological variation of Ontario otters. Canadian Journal of Zoology 5:1577-1583.

Stone, D., and O. Sheean-Stone. 1992. Otters. International Union for Conservation of Nature and Natural Resources, Species Survival Commission. Island Press, Covelo, California, USA.

Swimley, T. J., T. L. Serfass, R. P. Brooks, and W. M. Tzilkowski. 1998. Predicting river otter latrine sites in Pennsylvania. Wildlife Society Bulletin 26:836-845.

Tabor, J. E., and H. M. Wight. 1977. Population status of river otter in western Oregon. Journal of Wildlife Management 41:692-699.

Testa, J. W., D. F. Holleman, R. T. Boyer, and J. B. Faro. 1994. Estimating populations of marine river otters in Prince William Sound, Alaska, using radiotracer implants. Journal of Mammalogy 75:1021-1032.

Toweill, D. E., and J. E. Tabor. 1982. River otter (Lutra canadensis). Pages 688-703 in J. A. Chapman, and G. A. Feldhamer, editors. Wild mammals of North America. Johns Hopkins University Press, Baltimore, Maryland, USA. 
Tumlinson, R. M., and S. Shalaway. 1985. An annotated bibliography on the North American river otter. Oklahoma Cooperative Fish Wildlife Research Unit, Oklahoma State University, Stillwater, Oklahoma, USA.

United States Geological Survey. 2002. Hydrograph and station description for 03139000 Killbuck Creek, Ohio, USA.

Wayre, P. 1979. The private life of the otter. B. T. Bratsford Ltd., London, United Kindom.

Whitaker, J. O., and W. J. Hamilton. 1998. Mammals of the Eastern United States. Third edition. Cornell University Press, Ithaca, New York, USA.

Williams, T. D., and D. B. Siniff. 1983. Surgical implantation of radiotelemetry devices in the sea otter. Journal of American Veterinarian Medical Association 183:12901291.

Woolington, J. D. 1984. Habitat use and movements of river otters at Kelp Bay, Baranof Island, Alaska. Thesis, University of Alaska, Fairbanks, Alaska, USA. 
Table 1. River otter reintroduction programs in North America ${ }^{\mathrm{a}}$.

\begin{tabular}{|c|c|c|c|c|}
\hline State/Province & Year of initial release & No. otters released & Donor area(s) & No. release sites \\
\hline Alberta & 1981 & 21 & $\mathrm{AB}$ & unknown \\
\hline Arizona & 1981 & 46 & LA & 2 \\
\hline Colorado & 1976 & 94 & MI, MN, NL, OR, WA, WI & unknown \\
\hline Illinois & 1994 & 131 & LA & 6 \\
\hline Indiana & 1995 & 25 & LA & 1 \\
\hline Iowa & 1985 & 220 & LA & 11 \\
\hline Kansas & 1983 & 19 & ID, MN & 1 \\
\hline Kentucky & 1982 & 95 & LA & 4 \\
\hline Maryland & 1990 & 70 & MD & \\
\hline Minnesota & 1979 & 23 & $\mathrm{MN}$ & 1 \\
\hline Missouri & 1982 & 845 & $\mathrm{LA}, \mathrm{ON}$ & 42 \\
\hline Nebraska & 1986 & 159 & ID,LA, MT & 7 \\
\hline
\end{tabular}


Table 1. Continued.

\begin{tabular}{lcclc}
\hline \multicolumn{1}{c}{ State/Province } & Year of initial release & No. otters released & Donor area(s) & No. release sites \\
\hline New York & 1995 & 144 & NY & \\
North Carolina & unknown & 207 & unknown & LA, AK \\
Ohio & 1986 & 123 & LA \\
Oklahoma & 1984 & 17 & LA, MD, MI, NY \\
Pennsylvania & 1983 & 79 & LA \\
South Dakota & 1998 & 17 & LA, NC \\
Tennessee & 1983 & 21 & AK, NV \\
Utah & 1989 & 58 & LA, VA & unknown \\
Virginia & 1988 & 17 & MD, NC, SC, VA \\
West Virginia & 1984 & 34 & unknown \\
\hline a Data from & & & unknown
\end{tabular}

${ }^{\mathrm{a}}$ Data from Melquist and Dronkert (1987), Bluett and Hubert (1995), Raesly (2001) 
Table 2. Ohio river otter release sites.

\begin{tabular}{llccc}
\hline Watershed & Counties & No. of otters released & Size of watershed (ha) & Years \\
\hline Grand River & Trumbull & 48 & 182,590 & $1986-90$ \\
Killbuck Creek & Wayne/Holmes & 24 & 157,730 & 1991 \\
Stillwater Creek & Harrison & 25 & 123,540 & 1992 \\
Little Muskingum River & Monroe & 26 & 97,651 & 1993 \\
Total & & 123 & 561,511 & $1986-93$ \\
\hline
\end{tabular}


Table 3. Reported river otter harvest for the United States in 2000-2001 and 2001-2002.

\begin{tabular}{|c|c|c|}
\hline State & 2000-2001 & 2001-2002 \\
\hline Alabama & 174 & 319 \\
\hline Alaska & 951 & 1,213 \\
\hline Arkansas & N/A & 1,808 \\
\hline Connecticut & 167 & 216 \\
\hline Delaware & 17 & 59 \\
\hline Florida & 94 & 17 \\
\hline Georgia & 1,218 & 833 \\
\hline Idaho & 97 & 113 \\
\hline Louisiana & 4,593 & 2,579 \\
\hline Maine & 943 & 1,103 \\
\hline Maryland & 269 & 283 \\
\hline Massachusetts & 38 & 25 \\
\hline Michigan & 1,063 & 1,057 \\
\hline Minnesota & 2,301 & 2,145 \\
\hline Mississippi & 1,418 & 1,651 \\
\hline Missouri & 1,378 & 1,976 \\
\hline Montana & 60 & 100 \\
\hline New Hampshire & 291 & 397 \\
\hline New Jersey & N/A & 59 \\
\hline New York & 743 & 1,242 \\
\hline
\end{tabular}


Table 3. Continued.

\begin{tabular}{lcc}
\hline State & $2000-2001$ & $2001-2002$ \\
\hline North Carolina & 1,158 & 1,234 \\
Oregon & 445 & 466 \\
South Carolina & 660 & 519 \\
Tennessee & 435 & 452 \\
Texas & 910 & 904 \\
Vermont & 111 & 170 \\
Virginia & 985 & 916 \\
Washington & 83 & 138 \\
Wisconsin & 1,944 & 2,701 \\
Totals & 22,546 & 24,695 \\
\hline USFWS Unpublished Rept & & \\
\hline
\end{tabular}

USFWS Unpublished Report 
Figure 1. Location of the Killbuck Watershed, Ohio, where I conducted my river otter research in 2002 and 2003.

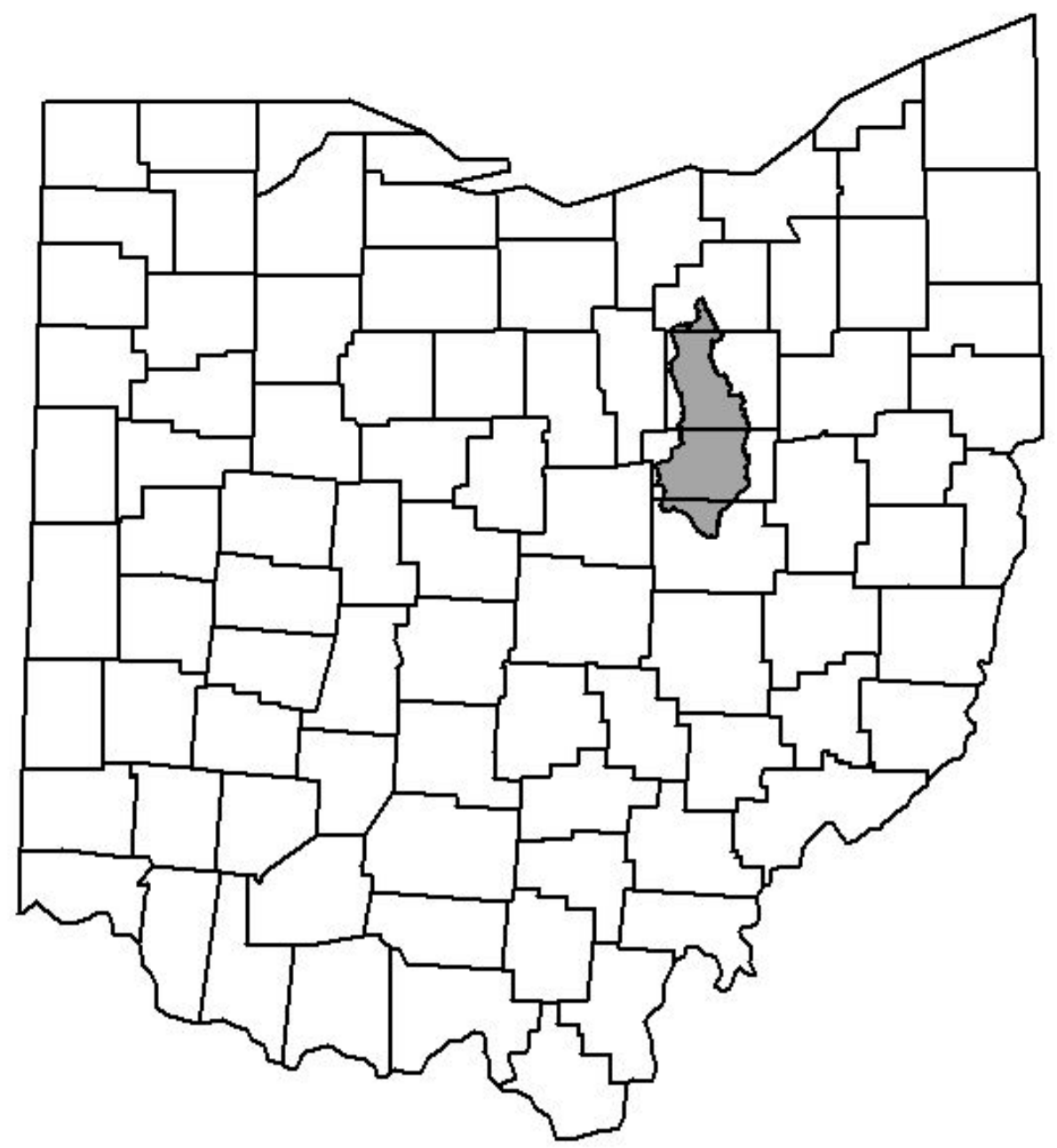


Figure 2. Riparian corridor along the Killbuck Creek at Killbuck Marsh Wildlife Management Area, Ohio 2003.




Figure 3. Flooding on the Killbuck Creek at Killbuck Marsh Wildlife Management Area, Ohio, 2003.

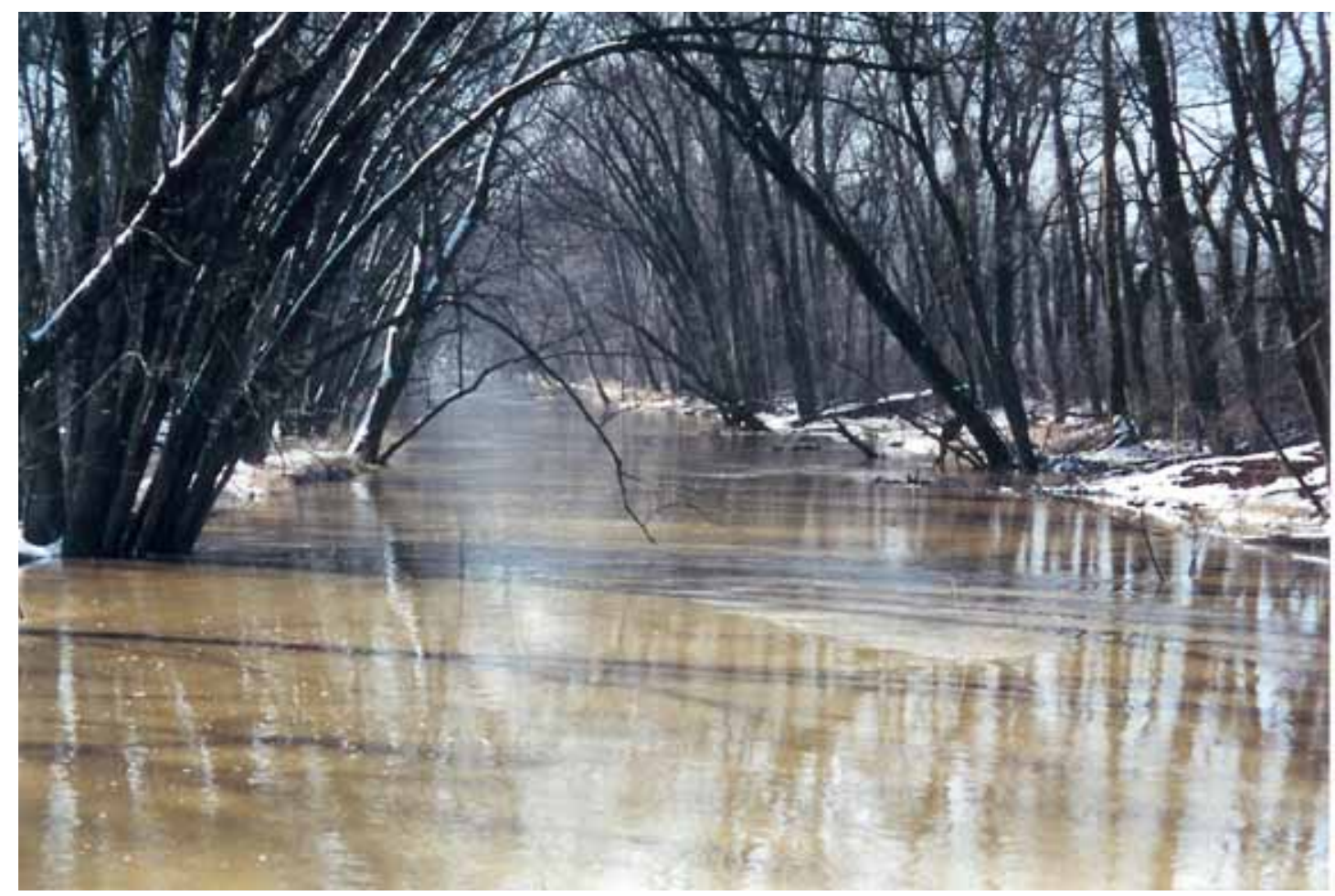


Figure 4. Palustrine emergent marsh at Killbuck Marsh Wildlife Management Area, Ohio 2003.




Figure 5. Scrub-shrub wetland at Killbuck Marsh Wildlife Management Area, Ohio, 2003.




Figure 6. Flooded timber at Killbuck Marsh Wildlife Management Area, Ohio, 2003.

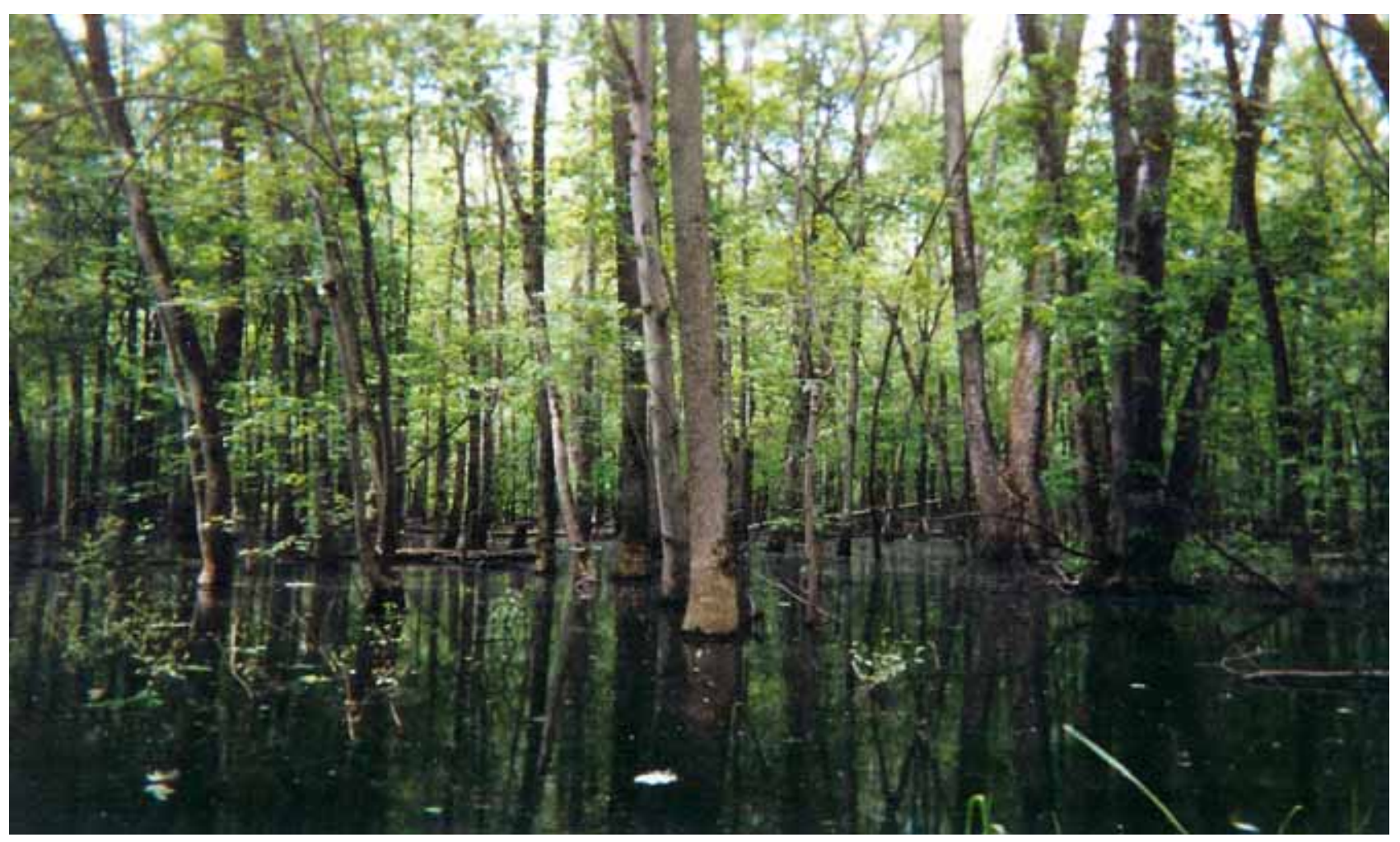


Figure 7. Wright's marsh located at the Killbuck Marsh Wildlife Management Area, Ohio, 2003.
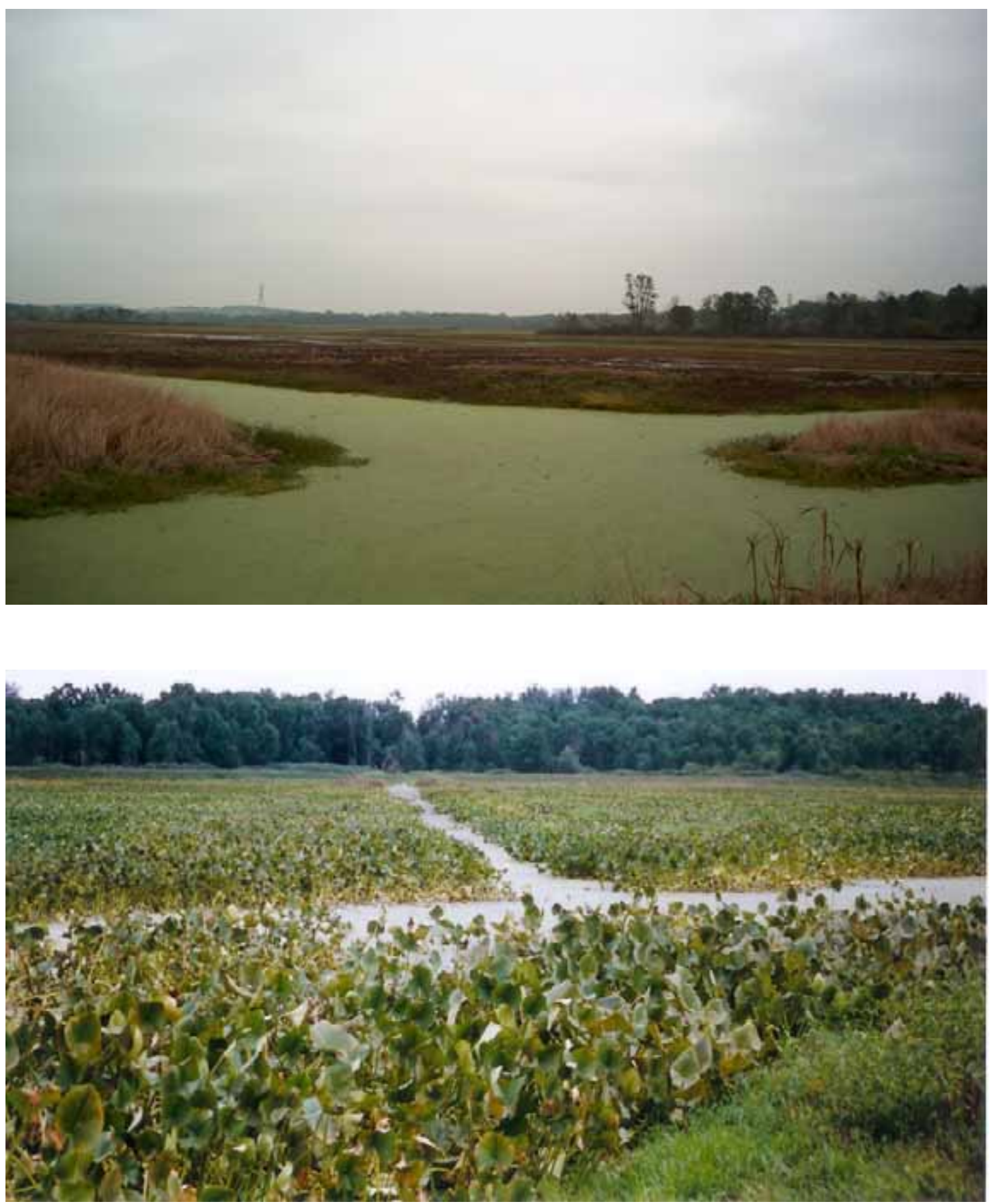


\section{CHAPTER 2}

\section{SUMMER HOME RANGE SIZE AND HABITAT USE BY RIVER OTTERS IN OHIO}

David A. Helon ${ }^{1}$, Wildlife and Fisheries Resources Program, Division of Forestry and Natural Resources, Box 6125, West Virginia University, Morgantown, WV 26506-6125, USA

James T. Anderson, Wildlife and Fisheries Resources Program, Division of Forestry and Natural Resources, Box 6125, West Virginia University, Morgantown, WV 26506-6125, USA

Chris P. Dwyer, Crane Creek Wildlife Experiment Station, Ohio Division of Wildlife, 13229 W. State Route 2, Oak Harbor, OH 43449, USA

John W. Edwards, Wildlife and Fisheries Resources Program, Division of Forestry and Natural Resources, Box 6125, West Virginia University, Morgantown, WV 26506-6125, USA

Abstract: Reintroduced river otters (Lontra canadensis) are an important component of Ohio's biological diversity, and are a key indicator of wetland and watershed health and quality. However, few data are available on their home range sizes and habitat use. We monitored river otters using radio-telemetry in the Killbuck Watershed, in northeastern Ohio, during 2002 and 2003 to determine home range and habitat use. Overall, mean home range size was 802.4 ha (range $=84.5-3,376.3, \mathrm{SE}=448.2)$ for female river otters

\footnotetext{
${ }^{1}$ Current address United States Department of Agriculture/APHIS/Wildlife Services/National Wildlife Research Center 6100 Columbus Avenue, Sandusky, Ohio 44870.
}

$\overline{\text { This chapter written in the style of the Proceedings of the IX } X^{\text {th }} \text { International Otter Colloquium. }}$ 
and $1,101.7$ ha $($ range $=713.8-1,502.6, \mathrm{SE}=102.2)$ for male river otters. Home range size of female and male river otters was similar in $2002(P=0.763)$, but males had larger home range size than females during $2003(P=0.001)$. Habitat selection differed significantly $(P<0.0001)$ in proportion to availability of the 5 habitat types (marsh, wet meadow, riparian/floodplain, open water, and flooded upland), using compositional analysis. Overall river otters used a marsh habitat with a diverse association of floating aquatics and emergent vegetation with standing water in greater proportion than was available. Knowledge and understanding of river otter habitat use and home range size in Ohio will help identify habitats suitable for managing river otters in the Midwestern United States.

Key words: Habitat use, home range, Killbuck Watershed, Lontra canadensis, radiotelemetry, river otter

\section{INTRODUCTION}

River otters (Lontra canadensis) are a native Ohio furbearer and are also an important indicator of riparian health. At one time, river otters were established throughout most of the major drainages in North America (Hall 1981, Schwartz and Schwartz 1995, Whitaker and Hamilton 1998, Raesly 2001). Prior to the 1900s, river otters occurred in northern Alaska and from eastern Newfoundland to the Aleutian Islands, extendeding into the southern states of Florida and Texas, but remained absent from most of the southwestern states (Chapman and Feldhamer 1982, Stone and SheeanStone 1992). Unregulated trapping, water pollution, and destruction of habitat caused heavy declines in river otter populations (Berg 1982, Stone and Sheean-Stone 1992). 
Due to high prices of fur in the 1970s, trapping pressure increased, causing harvest rates to escalate, and development of furbearer management strategies to occur (Chapman and Pursley 1980, Morrison et al. 1981).

Due to extensive reintroduction and translocation programs throughout North America, river otters have made a comeback. Several states have conducted studies and surveys to determine post-release survival and movements of river otters. However, there is a lack of long-term studies or any systematic effort to determine the status of reintroduced river otter populations (Raesly 2001). Since the release program ended in Ohio in 1989, monitoring the distribution and range expansion of river otters has consisted primarily of observational reports, bowhunter surveys, bridge surveys, and aerial surveys from Division of Wildlife personnel and the public.

Terrain, topography, habitat, and food resources are important variables that determine home range size. Most crucial is the type of habitat, which can influence prey availability and cover components. Mammal movements are a combination of activity, home range, migration, immigration, emigration, and movements associated with behavior and territory (Sanderson 1966, Erlinge 1967, Larsen 1983, Melquist and Hornocker 1983, McDonald 1989). River otter home ranges include areas in which the animals live, reproduce, and satisfy their life requirements (Melquist and Dronkert 1987).

Quality river otter habitat in Ohio is described by McDonald (1989) as having good water quality and high productivity bordered by large tracts of forest along aquatic systems. Long, meandering waterways, wooded riparian cover, abundant stream structure (e.g., logjams, fallen trees, debris piles), and a variety of wetland habitats (e.g., oxbows, flooded timber, backwater, emergent vegetation) also are considered important 
river otter habitats (Larsen 1983, Melquist and Hornocker 1983, Woolington 1984, Melquist and Dronkert 1987, McDonald 1989, Beck 1993). Determining habitat use of river otters in Ohio is important for river otter management and for identifying other potentially suitable areas that could be important translocation sites for relocating nuisance river otters or for expanding river otter populations throughout the Midwest.

Due to their enigmatic nature, river otters are difficult to observe (Swimley et al. 1998), and information pertinent to their management is often difficult to obtain. Although, the existing surveys provide a general indication of where river otters are known to occur, there is little information on habitat use, home range, movement, and activity patterns of river otters in Ohio. The objectives of this study were to: (1) describe home range and habitat use of river otters in the Killbuck Watershed, Ohio; and (2) determine if differences occurred between gender and years in home ranges and habitat use. The results of this study will create a baseline for identifying river otter habitat and improve the ability to scientifically manage river otters in Ohio and the upper Midwest.

\section{STUDY AREA}

Our study was centered on the Killbuck Wildlife Management Area (WMA) encompassing 2,234 ha in northeastern Ohio. The $132 \mathrm{~km}$ long Killbuck Creek flows through the WMA and drains the 157,730 ha watershed. This area is located in a glacial outwash valley with elevations ranging from $256 \mathrm{~m}$ at the floor of the Killbuck Creek to $305 \mathrm{~m}$ on paralleling hillsides. Over half of the WMA consists of palustrine emergent, palustrine scrub-shrub, and palustrine forested wetlands (Cowardin et al. 1979) that are flooded during some portion of the year. Killbuck WMA was acquired in 1969 by the state of Ohio and represents the largest remaining wetland complex in the state outside of 
the Lake Erie marsh region. Wildlife management activities consist of planting food patches, maintenance and protection of existing woodlands, establishment of regular crop rotations, and improvements and management of warm-season and cool-season grasses for wildlife by controlled burning and selective herbicide spraying. Several marshes adjacent to the Killbuck Creek are managed by draw-down techniques; however, several marshes in the area are void of any type of water management structures.

Fish species inhabiting Killbuck Creek include northern pike (Esox lucius), common carp (Cyprinus carpio), suckers (Catostomidae spp.), bullheads (Ameiurus spp.), and Centrarchid species. Beaver (Castor canadensis) populations have increased during the last several years, creating suitable habitat for a diversity of wildlife species (e.g., furbearers, waterfowl, waterbirds, shorebirds, fish, frogs, turtles, and songbirds). Killbuck WMA is an important area for migrating waterfowl and songbirds. Killbuck WMA is open to the public year-round, with hunting, trapping, fishing, and birding being the most popular activities. There are numerous county and township roads and parking areas throughout the WMA, allowing relatively easy access for the public.

\section{METHODS}

\section{Trapping}

We trapped river otters in the Killbuck Watershed, primarily on the Killbuck WMA, using Victor No. 1.5 padded coilsprings (Woodstream Corporation, Lititz, PA) and No. 11 double longspring offset foothold traps (Sleepy Creek Manufacturing, Berkeley Springs, WV). Coilspring traps were modified by the addition of 2 coil springs and reinforced base plates. All traps also were equipped with $90-\mathrm{cm}$ chains attached to the bottom center of base plates, and chains were modified by adding 5 swivels to allow 
trapped river otters to roll and avoid serious injury (Blundell et al. 1999). We anchored traps using wooden stakes, and the area surrounding each trap site was cleared of debris that could entangle captured river otters (Serfass et al. 1996, Bowyer et al. 2003). During cold weather conditions, traps were attached to a piece of 11 gauge wire that acted as a slide to allow the trapped river otters to get out of the water to avoid hypothermia. Traps were placed at river otter pull outs, latrine sites, and pocket sets using a combination of lures, such as crayfish and fish oils, as well as some commercial river otter lures. During 2001 and 2002 trapping was initiated in September, when the majority of young river otters are able to survive autonomously (Serfass et al. 1996), and continued through December. Trapping was terminated when overnight temperatures dropped below $-5^{\circ} \mathrm{C}$.

We guided river otters into transport boxes and weighed to determine the correct dosage of anesthetic. We anesthetized trapped river otters with ketamine hydrochloride at a ratio of $22 \mathrm{mg} / \mathrm{kg}$ (Melquist and Hornocker 1979, McDonald 1989, Testa et al. 1994) and a veterinarian implanted them with an intraperitoneal Advanced Telemetry Systems (ATS) M1200 (Advanced Telemetry Systems Inc., Isanti, MN) radio transmitter (30 mm $\times 100 \mathrm{~mm}$ weighing approximately $90 \mathrm{~g}$ ) using procedures outlined by Kollias (1999). Transmitters were equipped with a motion-sensitive mortality switch that is activated after about 8 hours of non-activity. We examined river otters for overall physical condition and possible injuries associated with foothold traps; they also were injected with vitamin B and vaccinated against Diptheria, Hepatitis, Leptosporosis, Parainfluenza, and Parvo Virus. The entire procedure, from time of anesthetization to the last shots were given, took about 35 minutes. An AVID (American Veterinary Identification Devices, Norco, CA) passive integrated transponder (PIT) tag ( was inserted under the 
skin at the base of the tail of each captured river otter to provide a permanent identification method. We easily identified recaptured river otters using an electronic PIT tag reader (Bowyer et al. 2003). Following surgery, we held river otters for a minimum of 5 hours in transport cages to ensure that they were in good health before releasing them at their respective capture sites (Rock et al. 1994, Testa et al. 1994). All river otters released showed no adverse effects from the procedures and were energetic. The West Virginia University Animal Care and Use Committee approved the protocols used in this study (01-0714).

\section{Radio-telemetry}

We monitored river otters with an ATS R2000 receiver for up to a 2-year period, on the ground using an omni-directional "whip" antennae mounted to the roof of a vehicle via a magnet. Once a signal was detected, we were able to locate it more accurately using a 3-element Yagi antenna. Each river otter was located approximately 3-4 times per week. We obtained locations throughout the summer, May through September 2002 and 2003, using ground tracking methods. We took telemetry locations as close to the animal as possible and temporal intervals were minimized $(<5 \mathrm{~min})$ between bearings (White and Garrot 1990). We determined river otter locations by triangulation from a minimum of 2 points from the ground. When river otters could not be located from the ground, we attempted to find them via a Bell 206 helicopter or a Partenavia PA-68 fixed wing, twin engine plane equipped with twin 4-element Yagi's operated by Ohio Division of Wildlife personnel.

During summer, river otters were monitored more intensively to enhance home range and habitat use models. We tracked river otters every 3 hours for a 24-hour period. 
We located river otters every 3 hours to minimize the possibility of autocorrelation among telemetry locations (White and Garrot 1990). Only river otters with $>30$ locations were retained in our data to determine home range and habitat selection (Aebischer et al. 1993).

\section{Data Analysis}

Universal Transverse Mercator (UTM) locations of river otters were estimated by entering coordinates of azimuths locations into program LOCATE II (Nams 1990). Locations were then entered into Animal Movement Analysis Extension (Hooge and Eichenlaub 1997) in ArcView ${ }^{\circledR}$ (Environmental Systems Research Institute, Redlands, California). Core home range size was determined using the 50\% Adaptive Kernel Method (AKM) and the 95\% AKM home range estimates (Worton 1989). We compared river otter home range size, using two-way analysis of variance (ANOVA) to determine if differences $(P<0.05)$ existed between gender and years. Assumptions of normality was tested using the PROC Univariate procedure in SAS (SAS Institute, Inc. 2000); we used Bartlett's test to test homogeneity of variance assumptions. We used logarithmic and square root transformations to convert dependent variables (home range) that did not meet assumptions.

Habitat use was categorized into 5 classifications: open water (deep water habitats with no vegetation), marsh (diverse associations of floating aquatics and emergent vegetation with standing water), wet meadow (homogenous stands of emergent vegetation), floodplains/riparian (low-lying area adjacent to aquatic system prone to flooding), and flooded upland (upland fields adjacent to aquatic systems that are prone to flooding), using Ohio wetland inventory digital quadrangle maps (1995) provided by 
Ohio Division of Wildlife. We calculated total number of river otter locations in each of the different habitat types. We used log-ratio compositional analysis for overall comparisons of habitat composition in river otter home ranges (Aebischer et al. 1993). A residual matrix was constructed from the matrix of log-ratio differences and was computed with Wilks' $\lambda$ to test for randomization among habitat use. We then constructed a matrix ranking habitat types and assigned differences among habitat type ranks (Aebischer et al. 1993). We also used the Neu et al. (1974) technique involving use of a Bonferroni-Z statistic to estimate habitat use. This technique is used to analyze utilization-availability data in conjunction with a chi-square test (Neu et al. 1974).

\section{RESULTS}

\section{Home Range}

During fall and winter of $2001(n=8)$ and $2002(n=9)$, we captured and radiotagged 17 river otters. We acquired adequate locations ( $>30)$ from 6 river otters $(3$ female, 3 male) during 2002, and 9 river otters (4 female, 5 male) during 2003 to estimate home range sizes and habitat use (Table 1). We monitored the same 4 river otters (2 female, 2 male) during both years.

Overall, mean home range size was 802.4 ha (range 84.5-3,376.3, $\mathrm{SE}=448.2$ ) for females and 1,101.7 ha (range 713.8-1,502.6, $\mathrm{SE}=102.2$ ) for males. Mean home range size was similar $\left(F_{1,14}=0.10, P=0.763\right)$ between genders in 2002 but was greater $\left(F_{1}\right.$, $14=21.1, P=0.001)$ for males than for females during 2003. Mean female home range size was greater $\left(F_{1,14}=15.15, P=0.003\right)$ in 2002 than in 2003 but there was no difference $\left(F_{1,14}=0.25, P=0.628\right)$ between home range size of males between years (Table 2). 
Overall, mean core home range size was 182.1 ha $($ range $=10.4-724.4, \mathrm{SE}=$ 101.6) for females and 220.5 ha (range $=101.9-368.7, \mathrm{SE}=29.4)$ for males. Mean core home range size was was similar $\left(F_{1,14}=0.82, P=0.384\right)$ between genders in 2002 but was greater $\left(F_{1,14}=8.35, P=0.015\right)$ for males than females during 2003. Mean female core home range size was greater $\left(F_{1,14}=11.15, P=0.007\right)$ in 2002 than in 2003 , but there was no difference $\left(F_{1,14}=0.03, P=0.864\right)$ between core home range size of males between years. Maps showing river otter home ranges, core ranges, and locations can be viewed in Appendix 1.

\section{Habitat Use}

Based on compositional analysis, river otter habitat use differed significantly (Wilks' $\lambda_{4}=0.20, P<0.0001$ ) among the 5 habitats. Habitat use was ranked in order of importance as: marsh $>$ flooded upland $>$ riparian/floodplain $>$ wet meadow $>$ open water. Marsh and riparian/floodplain habitats occurred in home ranges in greater proportion than other habitats.

Similarly, we found differences $\left(X^{2}{ }_{4}=399.9, P<0.0001\right)$ in use among the 5 habitat types using the Neu et al. (1974) technique (Table 3). Marsh habitat was used in greater proportion than was present in home ranges. Open water, riparian/floodplain, and flooded upland was used less than what was available and wet meadow was used in proportion to what was present in home ranges.

Locations of female river otters $(n=364)$ during 2002 and 2003, occurred in marsh areas most frequently (58\%), followed by riparian/floodplain areas (18\%). Similarly, male river otter locations during 2002 and $2003(n=417)$ most frequently occurred in marsh areas (57\%), followed by riparian/floodplain areas (21\%)(Appendix 3). 
For both female and male river otters, the fewest locations occurred in open water areas and wet meadows (Table 4).

\section{DISCUSSION}

\section{Home Range}

Home range sizes of river otters in our study were similar to those reported in other studies that have evaluated river otter home ranges (Larsen 1983, Melquist and Hornocker 1983, Erickson et al. 1984, Foy 1984, Melquist and Dronkert 1987). River otter home range and habitat use studies have been conducted in several habitat types, including high elevation areas, coastal marshes, and inland wetland complexes (Table 5). Typically, home ranges are larger in higher elevation areas then in low-lying areas that are abundant with wetland complexes, where food and shelter are more evenly distributed (Allen 1987, Melquist and Dronkert 1987, Mitsch and Gosselink 2000). River otter home range estimates vary from 184-461 ha in coastal Texas (Foy 1984) to 900-2,500 ha in coastal southeastern Alaska (Larsen 1983). Erickson et al. (1984) reported river otter home ranges at Swan Lake National Wildlife Refuge in Missouri to be 400-1,900 ha. Annual home range of river otters as large as 23,100 ha in Alberta, Canada was documented by Reid et al. (1994). Home range size for river otters in our study ranged from 85 ha to 3,376 ha.

The smallest home range size ( $85 \mathrm{ha}$ ) was exhibited by a female river otter that was observed with pups several times throughout the season (2003). Most of the time she was found using several dens in close proximity of each other. In contrast, the largest home range size $(3,376$ ha) in this study was exhibited by a female river otter that was observed multiple times during the field season (2002) without pups. This particular 
female river otter was located several times moving with some of the male river otters that also were radio-tagged. We decided to compare river otter home range size excluding female 185 from the data set using the same method as mentioned earlier. Similar results were found as before, female homerange size $\left(F_{1,13}=9.49, P=0.012\right)$ was greater in 2002 than during 2003with mean female home range sizes of 725.3 during 2002 and 197.4 during 2003. Typically, male river otters have larger home ranges then females (Ellis 1964, Melquist and Dronkert 1987, Reid et al. 1994), and lactating females usually have the most restricted home ranges (Polechla 1990). However, some studies have found no difference in home range sizes between females and males (Sjoasen 1997, Johnson and Berkley 1999).

\section{Habitat Use}

Habitat use of river otters in our study was comparable to other studies that have evaluated river otter habitat use (Mack 1985, McDonald 1989). The majority of our river otter locations for both females and males were in marshes. In Colorado and Ohio, Mack (1985) and McDonald (1989), respectively, found that during summer months river otters were found in beaver impoundments and marsh areas where slow moving water occurred most of the time. These impoundments have reduced current velocities, reduced silt loads, and increased organic matter allowing for clearer water (Brayton 1984, Naiman et al. 1986, Naiman et al. 1988). The clearer water allows river otters to feed more effectively (McDonald 1989). Foy (1984) found that river otters avoided muddy river systems when alternative habitat was present, although these river systems are important as travel corridors. In Idaho, during summer months, river otters occupying valley stream habitats were located $47 \%$ of the time in swamps/backwater sloughs, followed by 
mudflats and associated open marshes (Melquist and Hornocker 1983). In addition, river otters used open water areas least during spring and summer months (Melquist and Hornocker 1983). In Massachusetts river otters were found to use beaver impoundments at a higher rate than man-made impoundments (Newman and Griffin 1994), potentially due to high human use of man-made areas during summer months. Habitats identified as marsh, during our study, are classified as diverse associations of floating aquatics and emergent vegetation with standing water. These types of habitats typically have a high density of vegetative structure which provides habitat for a variety of prey species. Besides for foraging areas this type of habitat also provides river otters with denning/resting areas.

During our study we located female and male river otters in riparian/floodplain areas. These areas were difficult to access thus reducing human disturbances. Due to abundant rainfall during the 2003 season, many of these riparian/floodplain and adjacent upland habitats were underwater. We believe that this allowed the river otters access to larger areas to roam and forage for prey species moving to shallower water. It also provided them access to some terrestrial foods that were not previously available. Riparian and floodplains are important for river otters as denning/resting and foraging areas. Logjams, vegetation, and shallow water areas were abundant in these habitats. This type of structure provides areas for river otters to den and rest. Moreover, these structures allow prey species, such as carp (Cyprinus carpio), crayfish (Cambaridae) and frogs (Ranidae) to congregate, creating foraging areas for river otters during the summer months. 


\section{MANAGEMENT IMPLICATIONS}

River otters are able to adapt to a variety of aquatic systems, ranging from coastal areas to high mountain elevations to inland marsh and stream systems. Knowledge of river otter home range and habitat use is important to aid in management practices to reduce impacts on aquatic systems essential for river otters. This knowledge can be used in other parts of the upper Midwest to determine if there is sufficient habitat and if the area is large enough to provide river otter home range requirements.

Increasing development around the Killbuck Wildlife Management Area could cause a decline in adequate habitat for river otters. Several landowners, owning property along Killbuck Creek and its tributaries, recommend dredging and logjam removal to reduce flooding. Dredging and reduction of these logjams could negatively impact river otters, prey species, and other wildlife species. These decisions should involve both human needs and sound wildlife management decisions.

The Killbuck Watershed encompasses a variety of wetland complexes, allowing river otters to successfully survive and reproduce. Wetland management is essential to continue the diversity of wetlands crucial to river otters in this area. A variety of wetland ecosystems and aquatic corridors within the Killbuck Watershed allow river otters to disperse for emigration and immigration purposes. Management of these systems provides habitat for a diversity of prey species important for river otters. These areas should be managed to prevent dredging and to allow log piles, beaver ponds, and backwater sloughs to be created. These management approaches are important for creating denning/resting areas and foraging areas for river otters. Our results suggest that management for river otters should primarily focus on marsh habitats that are made up of 
diverse associations of floating aquatics and emergent vegetation with standing water. Floodplain/riparian habitats also should be managed and protected along with adjacent water corridors and occasionally flooded upland sites that are important for river otter dispersal and emigration. These marsh habitats, with a diversity of vegetative structure, provide areas for river otters to forage, and den/rest and adjacent aquatic corridors offer access to other wetland habitats with in watersheds. River otter management at the Killbuck WMA should continue to focus on wetland management (i.e., drawdowns) to create marsh habitats that provide a diversity of plant species. Logjams and woody debris should not be removed from aquatic corridors to allow a diversity of habitat and areas for prey species to congregate.

\section{ACKNOWLEDGMENTS}

Funding was provided by Ohio Division of Natural Resources, Division of Wildlife, Furbearers Unlimited, and Herb Metzger. We thank the West Virginia University Davis College of Agriculture, Forestry, and Consumer Sciences (McIntireStennis) and USDA/APHIS/WS/NWRC Ohio field station. We thank the numerous Ohio Division of Wildlife personnel including Joe Barber, Kevin Higgins, Dennis Solon, Jon Abele, and Erich Long for their help and support of this project. We also thank Lawrence E. Smith, DVM for his services with the river otters. Statistical assistance provided by George Seidel and Brian Washburn was greatly appreciated. 


\section{LITERATURE CITED}

Aebischer, N. J., P. A. Robertson, and R. E. Kenward. 1993. Compositional analysis of habitat use from animal radio-tracking data. Ecology 74:1313-1325.

Allen, W. A. 1987. The relationship between habitat and furbearers. Pages 164-179 in M. Novak, J. A. Baker, M. E. Obbard, and B. Malloch, editors. Wild furbearer management and conservation in North America. Ontario Trappers Association, North Bay, Ontario, Canada.

Beck, T. D. I. 1993. Development of river otter reintroduction procedures. Colorado Division of Wildlife, Research Review 2, Denver, Colorado, USA.

Berg, W. E. 1982. Reintroduction of fisher, pine marten, and river otter. Pages 159-174 in G. C. Sanderson, editors. Midwest furbearer management. North Central and Central Plains Sections of the Wildlife Society, Wichita, Kansas, USA.

Blundell, G. M., J. W. Kern, R. T. Bowyer, and L. K. Duffy. 1999. Capturing river otters: a comparison of Hancock and leg-hold traps. Wildlife Society Bulletin 27:184-192.

Bowyer, R. T., G. M. Blundell, M. Ben-David, S. C. Jewett, T. A. Dean, and L. K. Duffy. 2003. Effects of the Exxon Valdez oil spill on river otters: injury and recovery of a sentinel species. Wildlife Monographs 153:1-52.

Brayton, D. S. 1984. The beaver and the stream. Journal of Soil and Water Conservation 39:108-109.

Chapman, J. A., and D. Pursley, editors. 1980. Worldwide furbearer conference proceedings. Frostburg, Maryland, USA. 
Chapman, J. A., and G. A. Feldhamer. editors. 1982. Wild mammals of North America. The Johns Hopkins University Press, Baltimore, Maryland, USA.

Cowardin, L. M., V. Carter, and E. T. LaRoe. 1979. Classification of wetlands and deepwater habitats of the United States. U.S. Fish and Wildlife Service, Report FWS/OBS-79/31.

Ellis, R. J. 1964. Tracking raccoons by radio. Journal of Wildlife Management 28:363368.

Erickson, D. W., C. R. McCullough, and W. E. Porath. 1984. River otter investigations in Missouri. Missouri Department of Conservation., Pittman-Robertson Project W-13-R-38, Final Report. Columbia, Missouri, USA.

Erlinge, S. 1967. Home range of the otter Lutra lutra in southern Sweden. Oikos 18:186209.

Foy, M. K. 1984. Seasonal movement, home range, and habitat use of river otter in southeastern Texas. Thesis, Texas A\&M University, College Station, Texas, USA.

Hall, E. R. 1981. The mammals of North America. Second edition. John Wiley and Sons, New York, New York, USA.

Hooge, P. N., and B. Eichenlaub. 1997. Animal movement extension to ArcView. Version 1.1. U.S. Geological Survey, Alaska Biological Science Center, Anchorage, Alaska, USA.

Johnson, S. A., and K. A. Berkley. 1999. Restoring river otters in Indiana. Wildlife Society Bulletin 27:419-427. 
Kollias, G. V. 1999. Health assessment, medical management, and prerelease conditioning of translocated North American river otters. Pages 443-448 in M. E. Fowler, and E. Miller, editors. Therapy III-zoo and wild animal medicine. Philadelphia, Pennsylvania, USA.

Larsen, D. N. 1983. Habitats, movements and foods of river otters in coastal southeastern Alaska. Thesis, University of Alaska, Fairbanks, Alaska, USA.

Mack, C. M. 1985. River otter restoration in Grand County, Colorado. Thesis, Colorado State University, Fort Collins, Colorado, USA.

McDonald, K. P. 1989. Survival, home range, movements, habitat use, and feeding habits of reintroduced river otters in Ohio. Thesis, Ohio State University, Columbus, Ohio, USA.

Melquist, W. E., and M. G. Hornocker. 1979. Methods and techniques for studying and censusing river otter populations. Forest, Wildlife and Range Experiment Station Technical Report 8. University of Idaho, Moscow, USA. , and M. G. Hornocker. 1983. Ecology of river otters in west central Idaho. Wildlife Monograph 83:1-60. , and A. E. Dronkert. 1987. River otter. Pages 625-641 in M. Novak, J. A.

Baker, M. E. Obbard, and B. Malloch, editors. Wild furbearer management and conservation in North America. Ontario Trappers Association, North Bay, Ontario, Canada.

Mitsch, W. J., and J. G. Gosselink. 2000. Wetlands. Third edition. John Wiley and Sons, New York, New York, USA. 
Morrison, D. W., R. M. Edmunds, G. Linscombe, and J. W. Goertz. 1981. Evaluation of specific scent station variables in northcentral Louisiana. Proceedings of the Annual Conference of the Southeast Association of Fish and Wildllife Agencies $35: 281-291$.

Naiman, R. J., J. M. Melillo, and J. E. Hobbie. 1986. Ecosystem alteration of boreal forest streams by beaver (Castor canadensis). Ecology 67:1254-1269.

Naiman, R. J., C. A. Johnston, and J. C. Kelley. 1988. Alteration of North American streams by beaver. BioScience 38:753-762.

Nams, V. O. 1990. Locate II program. Pacer Publishing, Travo, Nova Scotia, Canada.

Neu, C. W., C. R. Byers, and J. M. Peek. 1974. A technique for analysis of utilizationavailability data. Journal of Wildlife Management 38:541-545.

Newman, D. G., and C. R. Griffin. 1994. Wetland use by river otters in Massachusetts. Journal of Wildlife Management 58:18-23.

Polechla, P. J. 1990. Action plan for North American otters. Pages 74-79 in P. FosterTurley, S. Macdonald, and C. Mason, editors. Otters: an action plan for their conservation. International Union for the Conservation of Nature and Natural Resources, Gland, Switzerland.

Raesley, E. J. 2001. Progress and status of river otter reintroduction projects in the United States. Wildlife Society Bulletin 29:856-862.

Reid, D. G., T. E. Code, and S. M. Herrero. 1994. Spacing, movements, and habitat selection of the river otter in boreal Alberta. Canadian Journal of Zoology $72: 1314-1324$. 
Rock, K. R., E. S. Rock, R. T. Bowyer, and J. B. Faro. 1994. Degree of association and use of a helper by coastal river otters, Lutra canadensis, in Prince William Sound, Alaska. The Canadian Field-Naturalist 108:367-369.

Sanderson, G. C. 1966. The study of mammal movements-A review. Journal of Wildlife Management 30:215-235.

SAS Institute, Inc. 2000. SAS user's guide: statistics, version 8 edition. SAS Institute, Inc. Cary, North Carolina, USA.

Schwartz, C. W., and E. R. Schwartz. 1995. The wild mammals of Missouri. Revised edition. University of Missouri Press, Columbia, Missouri, USA.

Serfass, T. L., R. P. Brooks, T. J. Swimley, L. M. Rymon, and A. H. Hayden. 1996. Considerations for capturing, handling, and translocating river otters. Wildlife Society Bulletin 24:25-31.

Sjoasen, T. 1997. Movements and establishment of reintroduced European otters Lutra lutra. Journal of Applied Ecology 34:1070-1080.

Statistix7. 2000. User's manual. Analytical software, Tallahassee, Florida, USA.

Stone, D., and O. Sheean-Stone. 1992. Otters. International Union for Conservation of Nature and Natural Resources, Species Survival Commission. Island Press, Covelo, California, USA.

Swimley, T. J., T. L. Serfass, R. P. Brooks, and W. M. Tzilkowski. 1998. Predicting river otter latrine sites in Pennsylvania. Wildlife Society Bulletin 26:836-845.

Testa, J. W., D. F. Holleman, R. T. Boyer, and J. B. Faro. 1994. Estimating populations of marine river otters in Prince William Sound, Alaska, using radiotracer implants. Journal of Mammalogy 75:1021-1032. 
Whitaker, J. O., and W. J. Hamilton. 1998. Mammals of the eastern United States. Third edition. Cornell University Press, Ithaca, New York, USA.

White, G. C. and R. A. Garrot. 1990. Analysis of wildlife radio-tracking data. Academic Press Incorporated, New York, New York, USA.

Woolington, J. D. 1984. Habitat use and movements of river otters at Kelp Bay, Baranof Island, Alaska. Thesis, University of Alaska, Fairbanks, Alaska, USA.

Worton, B. J. 1989. Kernel methods for estimating the utilization distribution in homerange studies. Ecology 70: 164-168. 
Table 1. Number of locations per river otter in the Killbuck Watershed, Ohio during 2002 and 2003.

\begin{tabular}{lllll}
\hline River otter ID & Gender & Tracking period & Year & No. of locations \\
\hline 064 & Female & May-August & 2002 & 52 \\
185 & Female & May-August & 2002 & 38 \\
222 & Female & May-August & 2002 & 47 \\
245 & Male & May-August & 2002 & 34 \\
325 & Male & May-August & 2002 & 43 \\
405 & Male & May-August & 2002 & 47 \\
064 & Female & May-August & 2003 & 49 \\
185 & Female & May-August & 2003 & 63 \\
222 & Female & May-August & 2003 & 59 \\
634 & Female & May-August & 2003 & 56 \\
325 & Male & May-August & 2003 & 55 \\
405 & Male & May-August & 2003 & 31 \\
652 & Male & May-August & 2003 & 48 \\
673 & Male & May-August & 2003 & 56 \\
753 & Male & May-August & 2003 & 52 \\
\hline
\end{tabular}


Table 2. Home ranges of river otters in the Killbuck Watershed, Ohio during 2002 and 2003.

\begin{tabular}{rrrrrr}
\hline Year & Gender & Home range & SE(95\%) & Core & SE(50\%) \\
\hline 2002,2003 & Female, Male & 962.0 & 211.1 & 202.6 & 48.2 \\
2002 & Female, Male & $1,297.7$ & 445.9 & 298.8 & 100.3 \\
2003 & Female, Male & 738.2 & 177.4 & 138.5 & 35.9 \\
2002,2003 & Female & 802.4 & 448.2 & 182.1 & 101.6 \\
2002 & Female & $1,608.9$ & 911.4 & 381.0 & 193.1 \\
2003 & Female & 197.4 & 56.4 & 33.0 & 12.4 \\
2002,2003 & Male & $1,101.7$ & 102.2 & 220.5 & 29.4 \\
2002 & Male & $1,608.9$ & 911.4 & 381.0 & 193.1 \\
2003 & Male & $1,170.9$ & 77.8 & 222.9 & 23.1 \\
\hline
\end{tabular}


Table 3. Confidence intervals (CI) of habitat use for river otters in the Killbuck Watershed, Ohio during 2002 and 2003.

\begin{tabular}{lccccc}
\hline \multirow{2}{*}{ Habitat } & \multicolumn{2}{c}{ Use: 95\% CI } & \multicolumn{3}{c}{ Available: 95\% CI } \\
\cline { 2 - 6 } & Upper & Lower & Upper & Lower & $\begin{array}{c}\text { Use vs. } \\
\text { Availabliity }\end{array}$ \\
\hline Open Water & 0.0644 & 0.0362 & 0.1193 & 0.0995 & Less \\
Marsh & 0.5684 & 0.5042 & 0.3401 & 0.2849 & More \\
Wet Meadow & 0.0730 & 0.0429 & 0.0500 & 0.0500 & Same \\
Riparian/Floodplain & 0.2336 & 0.1813 & 0.3379 & 0.2808 & Less \\
Flooded Upland & 0.1708 & 0.1251 & 0.2454 & 0.1921 & Less \\
\hline
\end{tabular}


Table 4. Number of locations (\% in parentheses) of radio-tagged river otters in each of 5 habitat types in the Killbuck Watershed, Ohio during 2002 and 2003.

\begin{tabular}{lcccccc}
\hline & \multicolumn{5}{c}{ No. Locations (\% of Total Locations) } \\
\hline Gender & Open Water & Marsh & Wet Meadow & Riparian/Floodplain & Flooded Upland & Other \\
Female & $26(7)$ & $212(58)$ & $21(6)$ & $64(18)$ & $41(11)$ & 364 \\
Male & $4(1)$ & $238(57)$ & $28(6)$ & $89(18)$ & $58(11)$ & 417 \\
Totals & $30(4)$ & $450(57)$ & $49(6)$ & $153(20)$ & $99(13)$ & 781 \\
\hline
\end{tabular}


Table 5. Home range estimates for river otters in other studies.

\begin{tabular}{|c|c|c|c|c|}
\hline State & Study location & Habitat & $\begin{array}{l}\text { Home range } \\
\text { estimate }\end{array}$ & Source \\
\hline \multirow[t]{2}{*}{ Alaska } & Cholomondeley Sound & Coastal & $900-2,500$ ha & Larsen (1983) \\
\hline & $\begin{array}{l}\text { Kelp Bay, Baranof } \\
\text { Island }\end{array}$ & Coastal & $100-2,300$ ha & Woolington (1984) \\
\hline Colorado & $\begin{array}{l}\text { Rocky Mountain } \\
\text { National Park }\end{array}$ & Mountain valley & $2,900-5,700$ ha & Mack (1985) \\
\hline Idaho & $\begin{array}{c}\text { North Fork Payette } \\
\text { River }\end{array}$ & Mountain valley & $800-7,800$ ha & $\begin{array}{c}\text { Melquist and } \\
\text { Hornocker (1983) }\end{array}$ \\
\hline \multirow[t]{2}{*}{ Missouri } & $\begin{array}{l}\text { Swan Lake National } \\
\text { Wildlife Refuge }\end{array}$ & $\begin{array}{l}\text { Inland marsh } \\
\text { and streams }\end{array}$ & $400-1,900$ ha & $\begin{array}{l}\text { Erickson et al. } \\
\text { (1984) }\end{array}$ \\
\hline & $\begin{array}{c}\text { Lamine River Wildlife } \\
\text { Area }\end{array}$ & $\begin{array}{l}\text { Inland marsh } \\
\text { and streams }\end{array}$ & $1,100-7,800 \mathrm{ha}$ & $\begin{array}{l}\text { Erickson et al. } \\
\text { (1984) }\end{array}$ \\
\hline Texas & $\begin{array}{l}\text { J. D. Murphee Wildlife } \\
\text { Management Area }\end{array}$ & Coastal marsh & 184-461 ha & Foy (1984) \\
\hline
\end{tabular}




\section{CHAPTER 3}

\section{SUMMER MOVEMENTS AND ACTIVITY PATTERNS OF RIVER OTTERS IN THE KILLBUCK WATERSHED, OHIO}

David A. Helon, Wildlife and Fisheries Resources Program, Division of Forestry and Natural Resources, Box 6125, West Virginia University, Morgantown, WV 26506-6125, USA

James T. Anderson, Wildlife and Fisheries Resources Program, Division of Forestry and Natural Resources, Box 6125, West Virginia University, Morgantown, WV 26506-6125, USA

Chris P. Dwyer, Crane Creek Wildlife Experiment Station, Ohio Division of Wildlife, 13229 W. State Route 2, Oak Harbor, OH 43449, USA

John W. Edwards, Wildlife and Fisheries Resources Program, Division of Forestry and Natural Resources, Box 6125, West Virginia University, Morgantown, WV 26506-6125, USA

Abstract: As part of a river otter (Lontra canadensis) study conducted in the Killbuck Watershed, the largest wetland complex in Ohio outside of the Lake Erie marshes, 11 river otters were radio-tagged and monitored for movements and activity patterns. Twenty-seven 24-hour monitoring surveys were conducted during summer months (MayAugust) of 2002 and 2003. The mean movement distance of female river otters $(\bar{x}=1.8$ $\mathrm{km}, \mathrm{SE}=0.23)$ was less $(P=0.0012)$ than the mean movement distance of male river otters $(\bar{x}=5.2 \mathrm{~km}, \mathrm{SE}=0.73)$. River otters were considered to be most active from $2201-0400 \mathrm{hrs}$ ( $71 \%$ of locations). Followed by $0401-1000 \mathrm{hrs}$ ( $68 \%$ of locations), $1601-2200 \mathrm{hrs}$ ( $45 \%$ of locations), and $1001-1600 \mathrm{hrs}$ (14\% of locations). It is important 
to understand river otter movement and activity patterns for successful management and reintroduction plans. These results show that river otters can move long distances and it is important to manage not only wetland systems but riparian corridors that aid in dispersal of river otters to other wetland complexes and watersheds.

Key words: activity patterns, Killbuck Watershed, Lontra canadensis, movements, river otter.

\section{INTRODUCTION}

River otters are important furbearers and indicators of riparian health in North America (Melquist and Hornocker 1983, Bowyer et al. 2003). Historically, river otters survived throughout northern Alaska, from eastern Newfoundland to the Aleutian Islands, and south to Florida and Texas, and were absent only in the treeless arctic and the arid southwestern states (Chapman and Feldhamer 1982, Melquist and Hornocker 1983, Melquist and Dronkert 1987, Stone and Sheean-Stone 1992). A combination of factors such as human infringement, habitat destruction, and overharvest reduced river otters from much of their historic range (Melquist and Hornocker 1983, Melquist and Dronkert 1987). Due to the high prices of fur in the 1970s, trapping pressure increased, causing harvest rates to escalate (Morrison et al. 1981). The increased harvest rates of river otters and other furbearers contributed to an increase in furbearer management and science based decisions (Chapman and Pursley 1980).

River otters are one of the most aquatic members of the Family Mustelidae (Melquist and Dronkert 1987), and are capable of traveling long distances in short time periods (McDonald 1989). River otters are highly mobile animals that can swim at speeds of up to $11 \mathrm{~km} / \mathrm{hour}$, and cover as much as $400 \mathrm{~m}$ underwater before coming up 
for air (Whitaker and Hamilton 1998). River otter movements vary from one area to another and are primarily dictated by drainage patterns (Melquist and Hornocker 1983, Melquist and Dronkert 1987, Bluett and Hubert 1995), but are also influenced by foraging, exploring, patrolling home ranges, marking boundaries, searching for mates, dispersal, and habitat quality (Erlinge 1967, Larsen 1983, Melquist and Hornocker 1983, McDonald 1989). Movements in high elevation areas may follow drainage systems that are long, linear, narrow, and branched. However, movements in coastal areas may be narrow in width following shorelines. Movements vary more in areas with little topographic relief and abundant wetlands and marshes (Melquist and Dronkert 1987).

Like many mammals, principal activity patterns of river otters are crepuscular (Melquist and Hornocker 1983, Whitaker and Hamilton 1998). Melquist and Hornocker (1983) and Mack (1985) attributed nocturnal activity during summer months to human avoidance. However, several studies have shown river otter activities at other times of the day (Larsen 1983, Melquist and Hornocker 1983, Foy 1984). Human disturbance can cause shifts in activity periods as well as other external factors (Melquist and Hornocker 1983, Bluett and Hubert 1995).

River otters have been reintroduced to several states and Canadian provinces where they previously survived in low numbers or were extirpated. Reestablishment of a native species, the potential for harvest, aesthetics, cultural significance, habitat availability, high fur value, public relations, and preservation of a locally rare or threatened species were reasons listed for river otter reintroductions (Berg 1982, Raesly 2001). A feasibility study was conducted in Ohio (1986-1987), and river otter reintroduction project was carried out to achieve the above objectives in the state from 
1988 through 1993 (Dwyer 2002). River otters $(n=123)$ were released in 4 separate watersheds throughout eastern Ohio (Grand River, $n=48$; Killbuck Creek, $n=24$; Stillwater Creek, $n=25$; and Little Muskingum River, $n=26$ ) (Dwyer 2002).

The objective of this study was to examine movement and activity patterns of river otters in the Killbuck Watershed, Ohio based on 24-hour monitoring periods (Foy 1984). Locations obtained during these periods are important in understanding movement patterns and the proximity/types of habitats used as well as movement corridors.

\section{STUDY AREA}

Our project was conducted throughout the Killbuck Watershed in northeastern Ohio (Fig. 1). Killbuck Creek runs through 3 counties (Wayne, Holmes, and Coshocton), within a watershed that includes 157,730 ha and a channel length of $132 \mathrm{~km}$. The upper end of the Killbuck Creek had a gentle slope of $39.1 \mathrm{~cm} / \mathrm{km}$ for the upper $3 \mathrm{~km}$ of the creek. In the southern end the topography was rougher and steeper along the tributaries that drain into the Killbuck (Beck et al. 1992). Forested riparian corridors exist along portions of the Killbuck; however, other areas were dredged frequently causing this aquatic river system to be highly prone to flooding, especially during periods of early spring due to snowmelt and rain events. Approximately $56 \%$ of this area consisted of palustrine emergent, palustrine scrub-shrub, and palustrine forested wetlands that were flooded during some portion of the year. The area is in the Mahoning-Canfield-RittmanChili soils region, part of the Eastern Ohio Till Plain, where glacial deposits ranged from coarse-textured to fine-textured, although coarser-textured and well drained soils occured more frequently in the southern portion of this region (Ohio Department of Natural 
Resources 1990). The Ohio Division of Wildlife (1999) acquired 2,234 ha of the Killbuck Watershed (Killbuck Wildlife Management Area) in 1969, which was Ohio's largest remaining wetland complex outside of the Lake Erie region.

Climate is typically hot and humid in the summer and moderately cold throughout the winter, with an average first fall freeze date $\left(0^{\circ} \mathrm{C}\right)$ occurring 6 October (National Oceanic and Atmospheric Administration 1982). Average annual precipitation is 91.4 $\mathrm{cm}$ for this area, with a monthly average of $7.6 \mathrm{~cm}$ (National Oceanic and Atmospheric Administration 1982). February is typically the driest month $(4.8 \mathrm{~cm})$ and July $(10.7 \mathrm{~cm})$ the wettest (National Oceanic and Atmospheric Administration 1982). The Killbuck can be influenced heavily by precipitation, with minimum daily flow rates ranging from 1.7 $\mathrm{m}^{3} / \mathrm{s}$ to $94.3 \mathrm{~m}^{3} / \mathrm{s}$ and a mean flow rate of $22.1 \mathrm{~m}^{3} / \mathrm{s}$ (United States Geological Survey 2002).

\section{METHODS}

\section{Trapping}

We trapped river otters in the Killbuck Watershed, primarily on the Killbuck WMA, using Victor No. 1.5 padded coilsprings (Woodstream Corporation, Lititz, PA) and No. 11 double longspring offset foothold traps (Sleepy Creek Manufacturing, Berkeley Springs, WV). Coilspring traps were modified by the addition of 2 coil springs and reinforced base plates. All traps also were equipped with $90-\mathrm{cm}$ chains attached to the bottom center of base plates, and chains were modified by adding 5 swivels to allow trapped river otters to roll and avoid serious injury (Blundell et al. 1999). Traps were staked using wooden stakes, and the area surrounding each trap site was cleared of debris that could entangle captured river otters (Serfass et al. 1996, Bowyer et al. 2003). During 
cold weather conditions, traps were attached to a piece of 11 gauge wire that acted as a slide to allow the trapped river otters to get out of the water to avoid hypothermia. Traps were placed at river otter pull outs, latrine sites, and pocket sets using a combination of lures, such as crayfish and fish oils, as well as some commercial river otter lures. During 2001 and 2002 trapping was initiated in September, when the majority of young river otters are able to survive autonomously (Serfass et al. 1996), and continued through December. Trapping was terminated when overnight temperatures dropped below $-5^{\circ} \mathrm{C}$.

We placed traps at river otter pull outs, cross-overs, latrine sites, and pocket sets using a combination of crayfish oil, fish oil, and commercial river otter lures. We guided trapped river otters into transport boxes (Fig. 3), transported them to a local veterinarian, and weighed them.

We placed trapped river otters in transport containers and driven to a veterinarian then were anesthetized with ketamine hydrochloride by a veterinarian at a rate of 22 mg/kg (Melquist and Hornocker 1979, McDonald 1989, Testa et al. 1994). The veterinarian then implanted a $30 \times 100 \mathrm{~mm}, 90 \mathrm{~g}$ intraperitoneal transmitter Advanced Telemetry Systems (ATS) M1200, as outlined by Kollias (1999). Transmitters were equipped with a motion sensitive mortality switch that activated after 8 hours of nonactivity. We also injected river otters with vitamin B and vaccines (Diptheria, Hepatitis, Leptosporosis, Parainfluenza, and Parvo Virus). An examination for overall physical condition and injuries that might have occurred from use of the foothold traps was performed. An AVID (American Veterinary Identification Devices, Norco, CA) passive integrated transponder (PIT) tag was inserted under the skin at the base of the tail of each captured river otter to provide permanent identification (Bowyer et al. 2003). 
Approximately 35 minutes was required for processing from the time anesthesia was administered until the last shots were given. Following surgery, we held river otters in captivity for $\leq 5$ hours in a transport cage to ensure that they were fully mobile, before being released (Testa et al. 1994) at their respective capture sites (Rock et al. 1994). Released river otters showed no adverse effects from the procedure and were energetic. The West Virginia University Animal Care and Use Committee approved the protocols used in this study (01-0714).

\section{Radio-telemetry}

We monitored river otters on the ground using an omni-directional "whip" antenna mounted to the roof of a vehicle and an ATS R2000 receivers. Once a signal was detected, we more accurately located the river otter using a 3-element Yagi antennae. We obtained locations on the ground during May through August of 2002 and 2003. We randomly assigned days and order of tracking and tracked each river otter once a month. During each 24-hour monitoring period 2-4 river otters were tracked. We obtained locations every 3 hours for a 24 -hour period (Table 1). Monitoring periods were conducted regardless of weather conditions, unless lightening was present, in which case the monitoring period was ended for safety reasons. We determined river otter locations by triangulation from a minimum of 2 points. River otters were located every 3 hours to minimize the possibility of autocorrelation among telemetry locations (White and Garrot 1990). We obtained telemetry readings as close to the animal as possible and temporal intervals were minimized $(<5 \mathrm{~min}$ ) between azimuths (White and Garrot 1990, Owen 2003). Average azimuth error was determined by the difference between azimuths taken on transmitters hidden in the wetland and the true azimuths from the telemetry station to 
the location of the transmitter. We calculated the average error polygon as the average size of the polygon created by the error arcs of 2 azimuths taken on a transmitter from 2 stations (Hurst and Lacki 1999). At the time of locating river otters we determined if the river otter was active or at rest (denned) by the signal fluctuations. If the signal was fluctuating, we assumed the river otter was moving or active, and was recorded as being at rest if little or no fluctuation occurred.

To determine peak activity periods of river otters, we divided the diel period into 46 hour periods (0401-1000, 1001-1600, 1601-2200, 2201-0400 hours) (McDonald 1989). Once a river otter was located, signal intensity was monitored for about 5 minutes to determine fluctuation in signal strength, which we assumed was due to movement and recorded the river otter active, we recorded no signal fluctuation as being non-active (at rest/denned) (Melquist and Hornocker 1983, McDonald 1989). The proportion of active and non-active locations during the 24-hour surveys were summed to get a percentage of activity patterns for each of the 4 time periods.

\section{Data Analysis}

We estimated Universal Transverse Mercator (UTM) locations by entering coordinates of azimuth locations into program LOCATE II (Nams 1990). We entered UTM coordinates into Animal Movement Analysis Extension (Hooge and Eichenlaub 2000) in ArcView ${ }^{\circledR}$ (Hooge and Eichenlaub 2000, Merrill and Mech 2003), and determined distance traveled between locations during the 3-hr intervals. We compared distance moved (independent variable) to determine differences between sexes and years (independent variable) $(P<0.05)$ using analysis of variance (ANOVA). We used $G$-tests to determine if the proportion of locations where river otters were active or non-active 
were different among time periods $(P<0.05)$. Following a significant $G$-test, we used $G$ tests to compare each pair of means. We tested assumptions of normality using the univariate procedure in SAS, and Bartlett's test to test homogeneity of variance assumptions. We used square root and natural $\log$ transformations to convert dependent variable (movements) that did not meet the normality assumptions (Dowdy and Wearden 1991).

\section{RESULTS}

During summer months (May-August) of 2002 and 200311 river otters were monitored for 27 24-hr activity periods. We monitored 6 river otters for 10 24-hour periods during 2002, 2 river otters for 1 period, and 4 river otters for 2 periods. In 2003 we tracked 9 river otters for 17 24-hour periods, 1 river otter for 1 period and 8 river otters for 2 periods (Table 1). One hundred ninety locations, divided into the 4 time periods $(0401-1000,1001-1600,1601-2200,2201-0400$ hours $)(\overline{\times}=47)$, were used to determine if river otters were active or at rest. Activity varied among the 4 time periods $\left(n=190, G_{3}=44.06, P<0.001\right)$. River otters were least active between 1001 and 1600 hours and most active between 2201 and 1000 (Table 2)(Appendix 2). There was a greater proportion of activity during the evening through the early morning hours (Fig. 4). The second peak of activity occurred early in the morning during the hours of 0400 through 0700 .

We found no interaction between sexes and years $\left(F_{1,26}=0.37, P=0.55\right)$ in mean distance moved. Mean distance moved differed $\left(F_{1,26}=13.71, P=0.0012\right)$ between females $(n=12 ; \bar{x}=1.8 \mathrm{~km} ; \mathrm{SE}=0.23$; range $=0.7-3.5)$ and males $(n=15 ; \bar{x}=5.2 \mathrm{~km}$; $\mathrm{SE}=0.73$; range $=0.7-9.9)$ during 2002 and 2003, with males moving greater distances 
than females. River otters moved an average of $3.2 \mathrm{~km}(n=9 ; \mathrm{SE}=1.07$; range $=0.7-$ 9.2) during 2002 and $3.9 \mathrm{~km}(n=18 ; \mathrm{SE}=0.60$; range $=0.8-9.9)$ during $2003\left(F_{1,26}=\right.$ $1.49, P=0.23$ ) during each 24-hr period.

\section{DISCUSSION}

Most river otter activity occurred during the early morning hours and evening hours with river otters staying active throughout much of the night (Larsen 1983, Melquist and Hornocker 1983, Foy 1984, Woolington 1984, Mack 1985, McDonald 1989). However, we recorded some activity during the middle of the day, as observed in several other studies (Larsen 1983, Melquist and Hornocker 1983, Foy 1984, Woolington 1984).

As with most mammals, male river otters will typically have larger home ranges, move greater distances, and be more active than females (Melquist and Hornocker 1983, Foy 1984, Griess 1987, McDonald 1989). It is important to understand river otter movement patterns for successful management and reintroduction plans. Den sites and prey sources were abundant in this study area, and mating activity was over at the time of the monitoring periods in this study which can alter movement patterns. Movement patterns that were monitored should be based on river otters hunting for prey for short periods of time and returning to a den site for periods of rest. Movements also could be due to exploring new territory which is important for restoration purposes, as well as patrolling home ranges. We found differences in movement between females and males over the 2 years (2002 and 2003), similar to other studies indicating male river otters moved greater distances than females (Melquist and Hornocker 1983, Foy 1984, Griess 1987, McDonald 1989) (Table 3). Larsen (1983) found mean male river otter movement 
in coastal southeastern Alaska to be $5.8 \mathrm{~km}$ compared to of $5.2 \mathrm{~km}$ in the present study. Melquist and Hornocker (1983) also reported a mean movement of $5.1 \mathrm{~km}$ for a 24-hour period for male rive otters in west central Idaho. Female river otters in Kelp Bay, Alaska were reported to have moved distances between 0-2.9 km (Foy 1984), and Melquist and Hornocker also observed females to have less movements than males. Most of the females that we were tracking were observed with pups, which likely influenced the localized movements. Female river otters were located at den sites in areas where prey species were abundant allowing them to forage close to dens. Much of their movement patterns consisted of short hunting and foraging expeditions close to the den, and returning for periods of rest. However, we did have one female river otter that moved $>40 \mathrm{~km}$ into another watershed. Due to the distance that she moved we were unable to track her and include her in our results. Overall males moved greater distances than females.

Distances moved do not necessarily equate to river otters covering large areas. Much of the movements observed were back and forth throughout wetland systems as river otters hunted and foraged for food, as well as patrolling and scent marking their territories (Erlinge 1968, Larsen 1983). Melquist and Hornocker (1983) mentioned the possibility that some of the long-distance movements can be associated with exploring unfamiliar areas. During 20022 male river otters $(284,325)$ moved distances of 9.2 and $8.4 \mathrm{~km}$ respectively, and 2 male river otters $(673,405)$ moved distances of 8.1 and 9.9 $\mathrm{km}$, respectively in 2003. These particular movements consisted of long distance movements to wetlands where they typically were not found throughout most of the study. These excursions can be similar to what Melquist and Hornocker (1983) observed 
during their study and may be caused by exploring new territories when they reported maximum long distance movements ranging from $7-42 \mathrm{~km}$.

The high quality habitat on the Killbuck WMA (i.e., 56\% palustrine scrub shrub, emergent, and forested wetlands) and the timing of the study (May-August) suggests that river otter movements were primarily influenced by foraging, exploring, or long-range dispersal by young river otters. Activity patterns can shift due to human disturbances or other factors such as prey availability, weather, and water conditions. Unlike many other predators, river otter diets allow them to obtain food at any time throughout a 24-hour period (Melquist and Dronkert 1987).

Throughout this study, there was little human traffic or disturbance on the study area. We conducted 24-hour surveys during May-August with average climate being hot and humid with day temperatures reaching $28^{\circ}-32^{\circ} \mathrm{C}$ (Ohio Department of Natural Resources 1990). Greatest movements occurred during the highest activity periods (0401-1000, and 2201-0400). The majority of the time, river otters were active throughout the morning, evening, and night, and remained denned up during the middle of the day. This may be due to the heat; river otters would use this time to den or rest, considering that they can hunt for food resources during cooler times of the day. Due to the heat in the middle of the day, we hypothesize that prey species are less active making them harder for river otters to locate. The combination of little movement and a plethora of cover (i.e., vegetation, woody debris) aid prey species to elude hunting river otters. However, prey species (i.e., fish, crustaceans, reptiles, amphibians, birds, and insects) are more abundant during this time of year (Weller 1981), allowing river otters to move less frequently and shorter distances while foraging to meet their daily intake requirements. 
Moreover, water levels usually drop and water pools start drying up during summer months concentrating prey species, which also can have an effect on river otter movements (Melquist and Hornocker 1983, McDonald 1989). Receding high water levels also landlock and concentrate prey species, allowing greater foraging success for river otters. Moreover, the topography of the Killbuck Watershed allows river otters to move great distances relatively easily. The Killbuck Creek runs through the center of the wildlife management area and adjacent to the creek are several managed and unmanaged marshes, and tributaries that offer an abundant food supply and cover for resting and denning.

We believe that most of the movements observed for females were short distance movements for feeding, foraging and hunting. They also may have included bouts of activity to teach pups how to swim, forage, and hunt. Male movements may also have been associated with feeding, along with locating other river otter latrines to determine if other males were in the area as well as marking their territories throughout their home range.

\section{MANAGEMENT IMPLICATIONS}

Knowledge of river otter activity patterns and movements is important to aid in management practices to reduce impacts on corridors important for river otter dispersal and emigration. The Killbuck Watershed is comprised of a variety of wetland habitats necessary for river otters to successfully survive and reproduce. Movement results suggest that quality habitat exists in the Killbuck Watershed allowing river otters to remain in this area without having to move great distances in search of prey and denning/resting sites. Continuation of management efforts to maintain wetland diversity 
is important for river otters in this area. The Killbuck Watershed offers a wide variety of wetland ecosystems with waterway corridors allowing river otters to move freely to a variety of wetlands as well as dispersal and emigration/immigration purposes. The majority of these aquatic corridors are forested with steep banks, and fluctuating water levels. These steep banks keep most of the river otter movements constrained to the main channel. Managing these wetland systems offer a variety of wetlands that in turn, provides habitat for a diversity of prey species used by river otters. Waterways also should be managed by preventing dredging so that log piles and backwater areas can be created, and to keep a wooded buffer along the banks. These recommendations are important for creating denning/resting areas, foraging areas, and dispersal corridors for river otters. These marsh habitats, with a diversity of vegetative structure, provide areas for river otters to forage and den/rest, and adjacent aquatic corridors offer access to other wetland habitats with in watersheds. River otter management at the Killbuck WMA should continue to focus on wetland management (i.e., drawdowns) to create marsh habitats that provide a diversity of plant species. Logjams and woody debris should not be removed from aquatic corridors to allow a diversity of habitat and areas for prey species to congregate.

\section{ACKNOWLEDGMENTS}

Funding was provided by Ohio Division of Natural Resources, Division of Wildlife, FurBearers Unlimited, and Herb Metzger. We thank the West Virginia University Davis College of Agriculture, Forestry, and Consumer Sciences (McIntireStennis) and USDA/APHIS/WS/NWRC Ohio field station. We thank the numerous Ohio Division of Wildlife personnel including Joe Barber, Kevin Higgins, Dennis Solon, John 
Abele, Mark Witt and Erich Long for their help and support of this project. We also thank Dr. Lawrence Smith DVM for providing surgical services for radio-marking river otters. Statistical assistance provided by George Seidel and Brian Washburn of USDA/APHIS/Wildlife Services/NWRC is also appreciated. 


\section{LITERATURE CITED}

Beck, T., K. M. Boone, and L. C. Brown. 1992. Wayne county water resources Ohio State University Extension Fact Sheet, AEX-480.85. Columbus, Ohio, USA.

Berg, W. E. 1982. Reintroduction of fisher, pine marten, and river otter. Pages 159-174 in G.C. Sanderson, editor. Midwest furbearer management. North Central and Central Plains Sections of the Wildlife Society, Wichita, Kansas,USA.

Bluett, R., and G. Hubert Jr. 1995. Background. Pages 1-22 in R. Bluett, editor. Illinois river otter recovery plan. Illinois Department of Natural Resources, Springfield, Illinois, USA.

Blundell, G. M., J. W. Kern, R. T. Bowyer, and L. K. Duffy. 1999. Capturing river otters: a comparison of Hancock and leg-hold traps. Wildlife Society Bulletin 27:184-192.

Bowyer, R. T., G. M. Blundell, M. Ben-David, S. C. Jewett, T. A. Dean, and L. K. Duffy. 2003. Effects of the Exxon Valdez oil spill on river otters: injury and recovery of a sentinel species. Wildlife Monographs 153:1-53.

Chapman, J. A., and D. Pursley, editors. 1980. Worldwide furbearer conference proceedings. Frostburg, Maryland, USA.

Chapman, J. A., and G. A. Feldhamer, editors. 1982. Wild mammals of North America. The Johns Hopkins University Press, Baltimore, Maryland, USA.

Dowdy, S., and S. Wearden. 1991. Statistics for research. John Wiley and Sons, New York, New York, USA.

Dwyer, C. P. 2002. Population assessment and distribution of river otters following their reintroduction into Ohio. Unpublished Report. Oak Harbor, Ohio, USA. 
Erlinge, S. 1967. Home range of the otter Lutra lutra in southern Sweden. Oikos 18:186209.

. 1968. Territoriality of the river otter Lutra lutra in southern Sweden. Oikos 18:259-270.

Foy, M. K. 1984. Seasonal movements, home range, and habitat use of river otter in southeastern Texas. Thesis, Texas A\&M University, College Station, Texas, USA.

Griess, J. M. 1987. River otter reintroduction in Great Smokey Mountains National Park. Thesis, University of Tennessee, Knoxville, Tennessee, USA.

Hooge, P. N., and B. Eichenlaub. 2000. Animal movement extension to ArcView. Version 2.2. U.S. Geological Survey, Alaska Biological Science Center, Anchorage, Alaska, USA.

Hurst, T. E., and M. J. Lacki. 1999. Roost selection, population size, and habitat use by a colony of Rafinnesque's big-eared bats (Corynorhinus rafinesquii). American Midland Naturalist. 142:363-371.

Kollias, G. V. 1999. Health assessment, medical management, and prerelease conditioning of translocated North American river otters. Pages 443-448 in M. E. Fowler, and E. Miller, editors. Therapy III-zoo and wild animal medicine. Philadelphia, Pennsylvania, USA.

Larsen, D. N. 1983. Habitats, movements and foods of river otters in coastal southeastern Alaska. Thesis, University of Alaska, Fairbanks, Alaska, USA.

Mack, C. M. 1985. River otter restoration in Grand County, Colorado. Thesis, Colorado State University, Fort Collins, Colorado, USA. 
McDonald, K. P. 1989. Survival, home range, movements, habitat use, and feeding habits of reintroduced river otters in Ohio. Thesis, Ohio State University, Columbus, Ohio, USA.

Melquist, W. E., and M. G. Hornocker. 1979. Methods and techniques for studying and censusing river otter populations. Forest, Wildlife, and Range Experiment, Station, Technical Report 8. University of Idaho, Moscow, Idaho, USA. , and M. G. Hornocker. 1983. Ecology of river otters in west central Idaho.

Wildlife Monographs 83:1-60.

, and A. E. Dronkert. 1987. River otter. Pages 625-641 in M. Novak, J. A.

Baker, M. E. Obbard, and B. Malloch, editors. Wild furbearer management and conservation in North America. Ontario Trappers Association, North Bay, Ontario, Canada.

Merrill, S. B., and L. D. Mech. 2003. The usefulness of GPS telemetry to study wolf circadian and social activity. Wildlife Society Bulletin 31:947-960.

Morrison, D. W., R. M. Edmunds, G. Linscombe, and J. W. Goertz. 1981. Evaluation of specific scent station variables in northcentral Louisiana. Proceedings of the Annual Conference of the Southeast Association of Fish and Wildlife Agencies 35:281-291.

Nams, V. O. 1990. Locate II program. Pacer Publishing, Travo, Nova Scotia, Canada. National Oceanic and Atmospheric Administration. 1982. Monthly normals of temperature, precipitation, and heating and cooling degree days, Ohio. Climatology of the United States, Number 81. Columbus, Ohio, USA. 
Ohio Department of Natural Resources. 1990. Soil regions of Ohio. Columbus, Ohio, USA.

Ohio Division of Wildlife. 1999. Killbuck marsh wildlife area. Publication 233(R901). Columbus, Ohio, USA.

Owen, S. F. 2003. Ecology and management of raccoons within an intensively managed forest in the central Appalachians. Dissertation, West Virginia University, Morgantown, West Virginia, USA.

Raesly, E. J. 2001. Progress and status of river otter reintroduction projects in the United States. Wildlife Society Bulletin 29:856-862.

Rock, K. R., E. S. Rock, R. T. Bowyer, and J. B. Faro. 1994. Degree of association and use of a helper by coastal river otters, Lutra canadensis, in Prince William Sound, Alaska. The Canadian Field-Naturalist 108:367-369.

Serfass, T. L., R. P. Brooks, T. J. Swimley, L. M. Rymon, and A. H. Hayden. 1996. Considerations for capturing, handling, and translocating river otters. Wildlife Society Bulletin 24:25-31.

Stone, D., and O. Sheean-Stone. 1992. Otters. International Union for Conservation of Nature and Natural Resources, Species Survival Commission. Island Press, Covelo, California, USA.

Testa, J. W., D. F. Holleman, R. T. Boyer, and J. B. Faro. 1994. Estimating populations of marine river otters in Prince William Sound, Alaska, using radiotracer implants. Journal of Mammalogy 75:1021-1032.

United States Geological Survey. 2002. Hydrograph and station description for 03139000. Killbuck Creek, Ohio, USA. 
Weller, M. W. 1981. Freshwater marshes ecology and wildlife management. University of Minnesota Press, Minneapolis, Minnesota, USA.

Whitaker, J. O., and W. J. Hamilton. 1998. Mammals of the Eastern United States. Ithaca, NY. Cornell University Press. Ithaca, New York, USA.

White, G. C. and R. A. Garrot. 1990. Analysis of wildlife radio-tracking data. Academic Press Inc., San Diego, California, USA.

Woolington, J. D. 1984. Habitat use and movements of river otters at Kelp Bay, Baranof Island, Alaska. Thesis, University of Alaska, Fairbanks, Alaska, USA. 
Table 1. Dates of 24-hour tracking periods for river otters in the Killbuck Watershed, Ohio during 2002 and 2003.

\begin{tabular}{|c|c|c|c|}
\hline Otter & Year & First Survey & Second Survey \\
\hline 064 & 2002 & 6 Jun $2002^{a}$ & 24-25 Jul 2002 \\
\hline 222 & 2002 & 19-20 Jun 2002 & 30-31 Jul 2002 \\
\hline 245 & 2002 & $* \mathrm{~b}$ & 9-10 Jul 2002 \\
\hline 284 & 2002 & $* b$ & 9-10 Jul 2002 \\
\hline 325 & 2002 & 19-20 Jun 2002 & 30-30 Jul 2002 \\
\hline 405 & 2002 & 13 Jun $2002^{a}$ & 24-25 Jul 2002 \\
\hline 064 & 2003 & 27-28 Jun 2003 & 10-11 Jul 2003 \\
\hline 185 & 2003 & 12-13 Jun 2003 & 10-11 Jul 2003 \\
\hline 222 & 2003 & 12-13 Jun 2003 & 6-7 Jul 2003 \\
\hline 325 & 2003 & 27-28 Jun 2003 & 18-19 Jul 2003 \\
\hline 405 & 2003 & 1-2 Jun 2003 & $* \mathrm{~b}$ \\
\hline 634 & 2003 & 12-13 Jun 2003 & 6-7 Jul 2003 \\
\hline 652 & 2003 & 1-2 Jun 2003 & 18-19 Jul 2003 \\
\hline 673 & 2003 & 12-13 Jun 2003 & 18-19 Jul 2003 \\
\hline 753 & 2003 & 27-28 Jun 2003 & 18-19 Jul 2003 \\
\hline
\end{tabular}

$\mathrm{a}=$ Survey ended early due to lightning.

$*^{\mathrm{b}}=$ River otters could not be located at that time period. 
Table 2. Proportion of locations during which river otters were active or non-active during summer months (May-August) in the Killbuck Watershed, Ohio during 2002 and 2003.

\begin{tabular}{|c|c|c|c|c|c|}
\hline \multirow[b]{3}{*}{$\begin{array}{c}\text { Time periods } \\
\text { (hrs) }\end{array}$} & \multirow[b]{3}{*}{$\begin{array}{c}\text { Total } \\
\text { locations }\end{array}$} & \multicolumn{4}{|c|}{ Location type $^{\mathrm{a}}$} \\
\hline & & \multicolumn{2}{|c|}{ Active } & \multicolumn{2}{|c|}{ Non-active } \\
\hline & & No. & $\%^{\mathrm{b}}$ & No. & $\%$ \\
\hline $0401-1000$ & 50 & 34 & $68 \% \mathrm{a}$ & 16 & $32 \%$ \\
\hline $1001-1600$ & 49 & 7 & $14 \% \mathrm{c}$ & 42 & $86 \%$ \\
\hline $1601-2200$ & 42 & 19 & $45 \% \mathrm{~b}$ & 23 & $55 \%$ \\
\hline $2201-0400$ & 49 & 35 & $71 \% \mathrm{a}$ & 14 & $29 \%$ \\
\hline
\end{tabular}

$\mathrm{a}=$ Active locations were determined by monitoring signal fluctuation for approximately 5 minutes.

${ }^{\mathrm{b}}=$ Proportions with the same letter are not different $(P>0.01)$ using paired $G$-tests. 
Table 3. Movement of river otter studies conducted across the USA.

\begin{tabular}{lccc}
\hline Investigator(s) & Study Location & Sex & Mean movement $(\mathrm{km})$ \\
\hline Larsen 1983 & coastal Alaska & male & 5.8 \\
Melquist and Hornocker 1983 & Idaho & male & 5.1 \\
& & female & 2.1 \\
Foy 1984 & Texas & male & 1.4 \\
& & female & 0.9 \\
Griess 1987 & Tennessee & male & 7.6 \\
Our study & & female & 7.2 \\
& Ohio & male & 5.2 \\
\hline
\end{tabular}


Figure 1. Location of the Killbuck Watershed, Ohio, where I conducted my river otter research in 2002 and 2003.

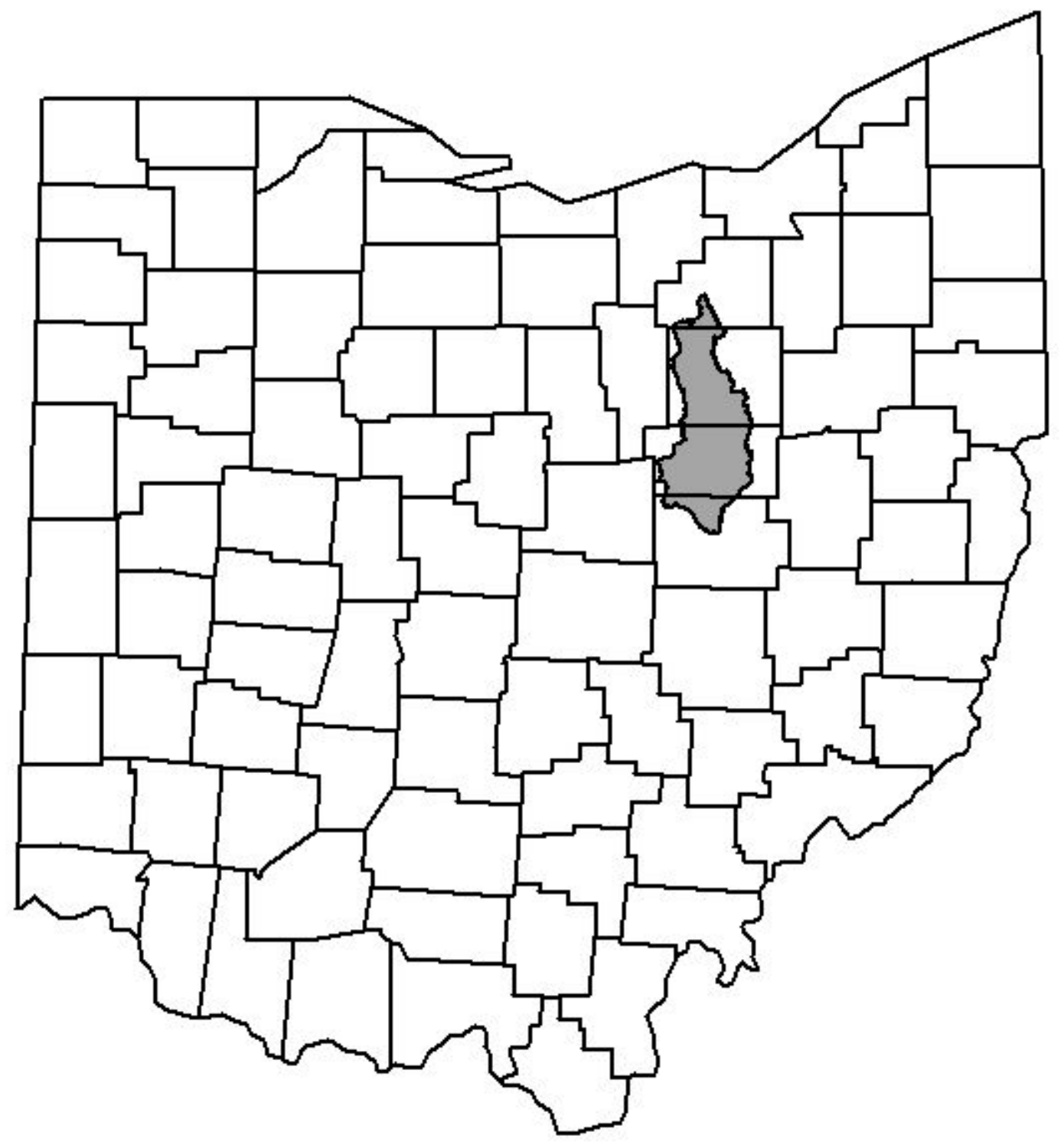


Figure 2. Traps used to catch river otters during our study. Victor 1.5 soft catch (top), Sleepy Creek \#11 (bottom).
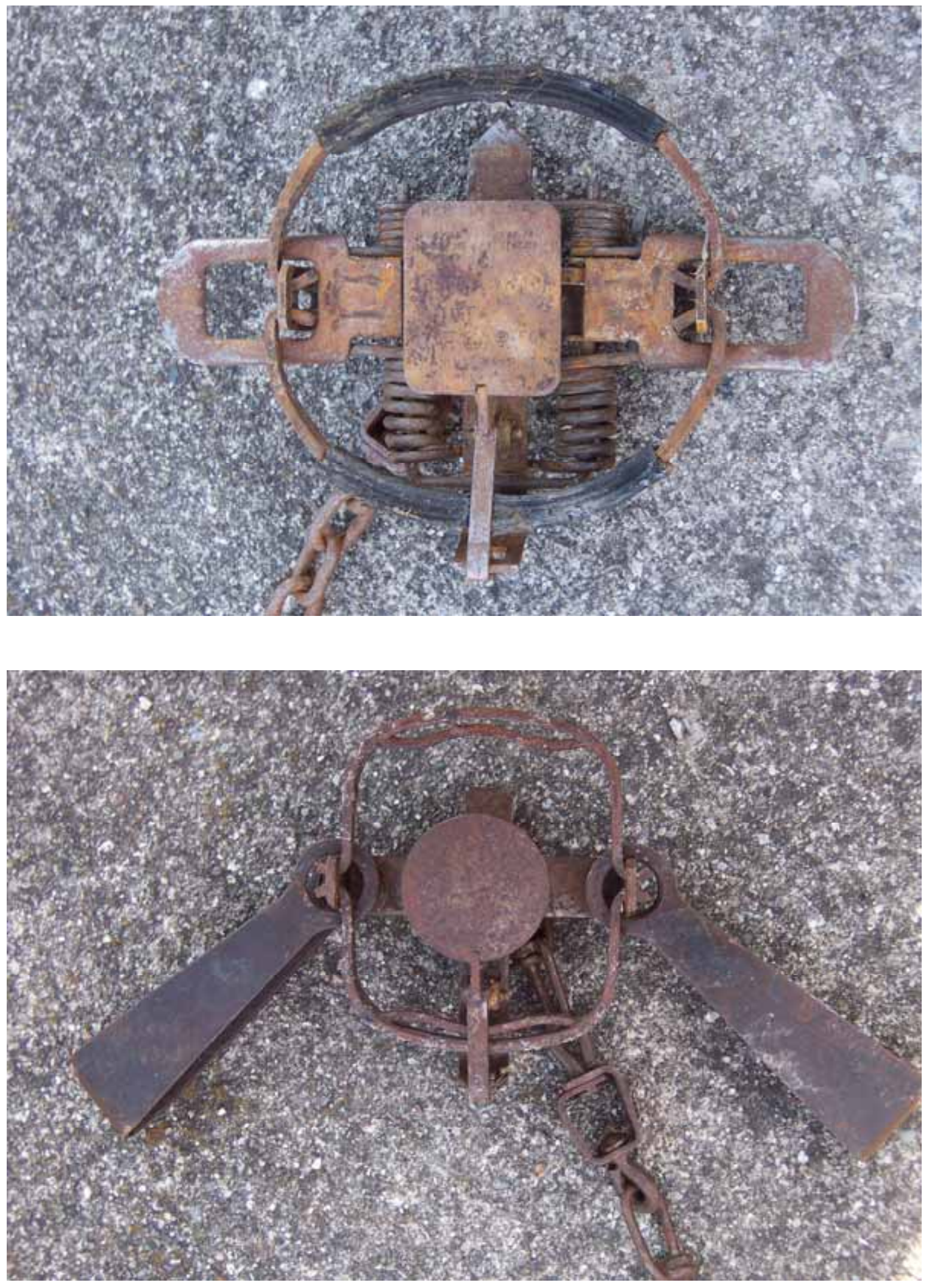
Figure 3. Immobilized river otter in transport box at veterinary facility.






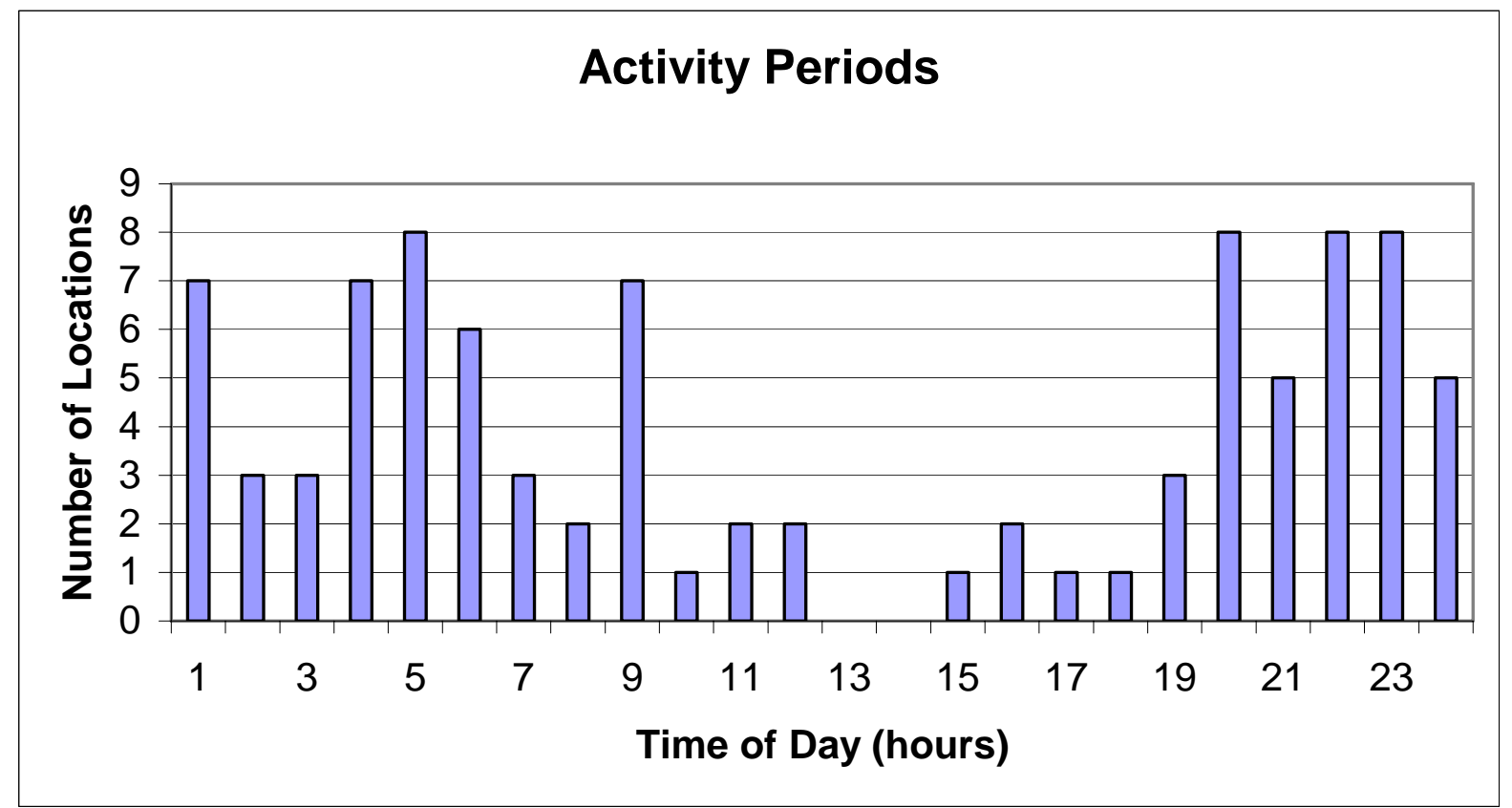

Figure 4. Number of locations (by hour) during which river otters were known to be active during (May-August) in the Killbuck Watershed during 2002 and 2003. 


\section{CHAPTER 4}

\section{CONCLUSIONS AND MANAGEMENT IMPLICATIONS}

River otter (Lontra canadensis) management is a relatively new practice in the wildlife management field. During the 1970s, several states conducted feasibility studies to reintroduce river otters into their native range, and by the 1990s, at least 22 states had released river otters (Melquist and Dronkert 1987, Bluett and Hubert 1995, Raesly 2001). Management of river otters requires considerable investment in money and time, and can differ according to monetary and personnel constraints, source populations, and public interests (Melquist and Dronkert 1987).

High pelt prices, enactment of the Endangered Species Act in 1973, a decline in upland wildlife hunting, and a growing number of anti-hunting/trapping organizations caused concern about management of furbearers during the 1970s (Chapman and Pursley 1980, Boggess et al. 1990). Hamilton and Fox (1987) divide furbearer management into 2 categories, habitat management and population management. However, habitat management specifically for furbearer is not a common practice. The most common population management techniques include calculating population indices, setting harvest regulations, and restricting harvest techniques (Hamilton and Fox 1987). Economical, biological, and managerial considerations and constraints all contribute to the difficulty of regulating harvest for furbearers (Fritzell and Johnson 1982, Hamilton and Fox 1987). Population management of river otters focuses mainly on 4 approaches: 1) enhancement of numbers in small populations or reestablishment of an extirpated population; 2) harvesting individuals from a population for a sustained yield; 3) stabilizing or lowering the density of a population; and 4) damage management (Melquist and Dronkert 1987, 
Bluett and Hubert 1995). In Ohio, river otter management started in 1986 when the Division of Wildlife began a feasibility study to reintroduce river otters into suitable watersheds, which included a radio-telemetry project to determine home range, habitat use, movements, and food items of river otters in the Grand River Watershed (McDonald 1989). River otters $(n=123)$ were subsequently released in 4 watersheds. Since then, river otter populations in the state have been monitored through an observation reporting system, bridge crossing surveys, a population model, aerial snow track surveys, bowhunter surveys, and evidence of reproduction via necropsies (Erickson and Hamilton 1988, Chris Dwyer Ohio Division of Wildlife, personal communication 2001). In 2001 a radio-telemetry study was initiated to determine annual survival rates, home range, habitat use, and movements of river otters in the Killbuck Watershed, located in northeast Ohio.

This study focused primarily on river otter spatial ecology within the Killbuck Watershed. This area has high quality river otter habitat based on criteria defined by McDonald (1989). Good riparian corridors exist along sections of Killbuck Creek. Several adjacent managed and natural wetlands and the wildlife management area comprised approximately 56\% palustrine emergent, palustrine scrub-shrub, and palustrine forested wetlands that are frequently used during some portion of the year (Ohio Division of Wildlife 1999). The wildlife area is closed to beaver (Castor canadensis) trapping to reduce accidental river otter catches in traps set for beavers. This area must continue to remain as a wildlife area to protect the habitat from development and urbanization.

Historically, river otters occurred throughout most of North America and were absent in the treeless arctic and the arid southwest states (Chapman and Feldhamer 1982, 
Melquist and Hornocker 1983, Melquist and Dronkert 1987, Stone and Sheean-Stone 1992). River otters spend the majority of their time in water, so they are restricted to wetland and deepwater habitats (Lariviere and Walton 1998). Habitats range from mountain streams (Melquist and Hornocker 1983), coastal wetlands (Foy 1984), and inland marshes with extensive wetland complexes. This study suggests that river otters in the Killbuck Watershed primarily used palustrine emergent, palustrine forested wetlands, and open water wetlands during the summer. Palustrine emergent and palustrine-forested wetlands provide ample food resources and denning/resting areas for river otters. These areas have abundant vegetation and debris (i.e., beaver lodges, snags, coarse woody debris, logjams, and hummocks) that offer cover for prey species such as fish, amphibians, and crustaceans which are considered important food items for river otters (Liers 1951, Toweill and Tabor 1982, Melquist and Hornocker 1983, Melquist and Dronkert 1987, McDonald 1989, Beckel 1990).

Development around the Killbuck Wildlife Management Area is increasing, and could potentially cause a reduction in adequate habitat for river otters. Many landowners, who own property along Killbuck Creek and its tributaries, recommend that the water systems be dredged and logjams be cleared to prevent flooding. Dredging and reduction of logjams can negatively impact river otters in this area, because these riparian corridors along the Killbuck Creek and other aquatic systems are important for river otters as well as many other species of wildlife. Logjam removal decisions should involve both human needs and sound wildlife management. Logjams can be important for denning/resting sites, stabilizing water levels, and diversifying habitats important to a wide variety of wildlife species such as wood ducks (Aix sponsa);(Bellrose and Holm 1994), mink 
(Mustela vison);(Schwartz and Schwartz 1981), beaver (Whitaker and Hamilton 1998), several species of fish (Trautman 1981), and bald eagles (Haliaeetus leucocephalus). Riparian areas also are important as movement corridors for river otters and other wildlife species dispersing to other watersheds. River otter movement between watersheds helps with genetic variability, which is a concern with river otter populations since most gene flow occurs within watersheds (McDonald 1989, Serfass et al. 1998). Through the use of observation cards, bridge surveys, and other techniques, river otters have been reported in numerous watersheds throughout Ohio that were not release sites. This suggests that the river otter population is increasing and expanding outside of the release sites, most likely the result of dispersal or movements from other release sites, both inside and outside of Ohio (Chris Dwyer, Ohio Division of Wildlife, personal communication, 2004). Since early 1980 s to mid 1990 s, river otters have also been released in Pennsylvania (Serfass et al. 1986), West Virginia (Bottoroff et al. 1976), Kentucky (Anderson 1995), and Indiana (Johnson and Berkley 1999).

Riparian corridors are important and need to be managed for both human needs and wildlife. These corridors need to be managed to control water levels to alleviate flooding of towns located in the vicinity as well as reduce flooding of agriculture fields. At the same time these corridors are important for a wide variety of wildlife species for movement among fragmented marshes in this region. It is important to educate the public about the importance of riparian habitats and perhaps encourage easement programs that protect riparian corridors. It also is important to determine potential conflict situations, such as areas with fish hatcheries or farm ponds, and develop solutions to reduce conflicts with sport fisheries and other wildlife species. 
Population modeling should continue in Ohio to monitor the population to determine if the population is increasing, decreasing, or stabilizing. Wildlife populations need to be monitored to prevent a drastic population increase to ensure their numbers remain within the limits of human tolerance (i.e., beavers, Canada geese [Branta canadensis], coyotes [Canis latrans], and white-tailed deer [Odocoileus virginianus]). Necropsies should continue on female river otters to determine reproductive rates in Ohio as well as specific watersheds (Gallagher 1999). Tooth extractions are important as well and should continue to evaluate age composition of the population (Chris Dwyer, Ohio Division of Wildlife, personal communication, 2002). Contaminant levels also should be monitored in specific watersheds to determine whether there is a measurable impact on river otter health and reproduction.

Habitat use data from this study can be used to help identify other suitable river otter habitat that is currently vacant. Identifying such areas is important for determining whether river otter populations in Ohio have room to grow, as well as identifying possible relocation sites for moving river otters that are causing conflicts with humans (i.e., private pond owners and fish hatcheries). Although the river otter population in Ohio has shown an increase, there are several watersheds that continue to remain void of river otters. Habitat use data can help determine if these watersheds lack components that are considered important to river otters, or if they lack aquatic corridors enabling river otters to move into or out of these watersheds. It is important to have large wetland complexes (i.e., river systems, deepwater, beaver ponds, and diverse marshes) to satisfy the requirements of river otters year-round. 
Translocation of river otters to areas that are currently void could help increase population size and diversify river otter genetics within watersheds. Translocations should be targeted at Wildlife Management Areas where habitat is suitable and populations can be monitored for accidental harvest by beaver trappers. Such areas could be closed to beaver trapping or regulated to require trappers to use river otter avoidance techniques (Ohio Division of Wildlife 2004). In other areas it is important to educate trappers in identification of river otter sign and either avoid such areas or avoid setting in main channels or crossovers where river otter sign is present. Incidental snaring of river otters also can be reduced by setting snare loops at $25.4-30.5 \mathrm{~cm}(10-12 \mathrm{in})$ diameter while beaver trapping (Ohio Division of Wildlife 2004).

River otter management and research have a symbiotic relationship and are important to scientifically manage this species properly. Research, surveys, inventories, habitat protection and improvement, education, and law enforcement should continue to be used to refine management plans. Although much has been learned about river otters in the Killbuck Watershed, there is still much to be learned about river otters to properly manage them in Ohio as well as other places in North America. Specific research should focus on:

(1) Studies on home range, habitat use, and movements during all seasons;

(2) Movements and dispersal of river otters along riparian corridors and major river systems;

(3) Bio-accumulation of pollutants in river otters occurring in different watersheds and their implications for reproductive health;

(4) Identify suitable habitats that are currently void of river otters;

(5) Evaluating river otter densities in watersheds; 
(6) Determining age specific reproductive rates of female river otters to refine population models;

(7) Calculating seasonal diets of river otters and comparing food items from different watersheds; and

(8) Determining cost effective tool for detecting changes in river otter populations; and

(9) Age specific recruitment rates of river otters.

Specific Management Objectives should focus on:

(1) Stabilizing populations in areas of high river otter abundance;

(2) Allowing populations to expand into and increase in areas that currently have low river otter numbers; and

(3) Developing information and materials for private landowners on pond management and identifying and dealing with river otter conflicts; and

(4) Promoting public use and appreciation of river otters and their habitats. 


\section{LITERATURE CITED}

Anderson, E. 1995. Status in the Midwest and Illinois. Pages 23-32 in R. Bluett, editor. Illinois river otter recovery plan. Illinois Department of Natural Resources, Springfield, Illinois, USA.

Bellrose, F. C., and D. J. Holm. 1994. Habitat. Pages 37-78 in G. C. Sanderson, R E. McCabe, and A. Hodgins, editors. Ecology and management of the wood duck. Stackpole Books, Mechanicsburg, Pennsylvania, USA.

Beckel, A. L. 1990. Foraging success rates on North American river otters, Lutra canadensis, hunting alone and hunting in pairs. The Canadian Field-naturalist 104:586-588.

Bluett, R., and G. Hubert Jr. 1995. Background. Pages 1-22 in R. Bluett, editor. Illinois river otter recovery plan. Illinois Department of Natural Resources, Springfield, Illinois, USA.

Boggess, E. K., G. R. Batcheller, D. W. Erickson, J. W. Greer, D. C. Juve, S. B. Linhart, R. G. Linscombe, M. Novak, A. W. Todd, and D. A. Wade. 1990. Traps, trapping, and furbearer management. Wildlife Society Technical Review 90-1.

Bottoroff, J. A., R. A. Wigal, D. Purlsey, and J. I. Cromer. 1976. The feasibility of river otter reintroduction in West Virginia. Special Report, West Virginia Deptartment of Natural Resources, Division of Wildlife, Charleston, West Virginia, USA.

Chapman, J. A., and D. Pursley, editors. 1980. Worldwide furbearer conference proceedings. Frostburg, Maryland, USA.

Chapman, J. A., and G. A. Feldhammer, editors. 1982. Wild mammals of North America. The Johns Hopkins University Press, Baltimore, Maryland, USA. 
Erickson, D. W., and D. A. Hamilton. 1988. Approaches to river otter restoration in Missouri. Transactions of the $53^{\text {rd }}$ North American Wildlife and Natural Resource Conference 53:404-413.

Foy, M. K. 1984. Seasonal movement, home range, and habitat use of river otter in southeastern Texas. Thesis, Texas A\&M University, College Station, Texas, USA.

Fritzell, E. K., and N. F. Johnson. 1982. A perspective on furbearer management. Pages 1-9 in G. C. Sanderson, editor. Midwest furbearer management. Proceedings of Symposium of the $43^{\text {rd }}$ Midwest Fish and Wildlife Conference, Wichita, Kansas, USA.

Gallagher, E. 1999. Monitoring trends in reintroduced river otter populations. Thesis, University of Missouri, Columbia, Missouri, USA.

Hamilton, D. A., and L. B. Fox. 1987. Wild furbearer management in the midwestern United States. Pages 1100-1116 in M. Novak, J. A. Baker, M. E. Obbard, and B. Malloch, editors. Wild furbearer management and conservation in North America. Ontario Trappers Association, North Bay, Ontario, Canada.

Johnson, S. A. and K. A. Berkley. 1999. Restoring river otters in Indiana. Wildlife Society Bulletin 27:419-427.

Lariviere, S., and L. R. Walton. 1998. Mammalian species account: Lontra canadensis. American Society of Mammalogists 587:1-8.

Liers, E. M. 1951. Notes on the river otter (Lutra canadensis). Journal of Mammalogy $32: 19$. 
McDonald, K. P. 1989. Survival, home range, movements, habitat use, and feeding habits of reintroduced river otters in Ohio. Thesis, Ohio State University, Columbus, Ohio, USA.

Melquist, W. E., and M. G. Hornocker. 1983. Ecology of river otters in west central Idaho. Wildlife Monographs 83:1-60. , and A. E. Dronkert. 1987. River otter. Pages 625-641 in M. Novak, J. A. Baker, M. E. Obbard, and B. Malloch, editors. Wild furbearer management and conservation in North America. Ontario Trappers Association, North Bay, Ontario, Canada.

Ohio Division of Wildlife. 1999. Killbuck marsh wildlife area. Publication 233 (R901). . 2004. Ohio hunting and trapping regulations. Columbus,

\section{Ohio USA.}

Raesly, E. J. 2001. Progress and status of river otter reintroduction projects in the United States. Wildlife Society Bulletin 29:856-862.

Schwartz, C. W., and E. R. Schwartz. 1981. The wild mammals of Missouri. University of Missouri Press and Missouri Department of Conservation, Columbia and London, Missouri, USA.

Serfass, T. L., R. P. Brooks, J. M. Novak, P. E. Johns, and O. E. Rhodes Jr. 1998. Genetic variation among populations of river otters in North America: considerations for reintroduction projects. Journal of Mammalogy 79:736-746. , L. M. Rymon, and J. D. Hassinger. 1986. Development and progress of Pennsylvania's river otter reintroduction program. Pages 322-343 in S.K. Majundar, F.J. Brenner, and A.F. Rhoads, editors. Endangered and threatened 
species programs in Pennsylvania and other states: causes, issues, and management. Pennsylvania Academy of Sciences, Harrisburg, Pennsylvania, USA.

Stone, D., and O. Sheean-Stone. 1992. Otters. International Union for Conservation of Nature and Natural Resources, Species Survival Commission. Island Press, Covelo, California, USA.

Toweill, D. E., and J. E. Tabor. 1982. River otter (Lutra canadensis). Pages 688-703 in J. A. Chapman, and G. A. Feldhamer, editors. Wild mammals of North America. John Hopkkins University Press, Baltimore, Maryland, USA.

Trautman, M. B. 1981. The fishes of Ohio. Revised Edition. Ohio State University Press, Columbus, Ohio, USA.

Whitaker, J. O., and W. J. Hamilton. 1998. Mammals of the eastern United States. Third Edition. Cornell University Press, Ithaca, New York, USA. 
Appendix 1. Summer home range and core ranges of river otters in the Killbuck Watershed, Ohio during 2002 and 2003.

This key is used for all maps.



Marsh

Open Water

Riparian/Floodplain

Wet Meadow

Flooded Upland

Other

Developed 
Female river otter 064 summer home range, core range, and locations in the Killbuck Watershed, Ohio during 2002.




Female river otter 185 summer home range, core range, and locations in the Killbuck Watershed, Ohio during 2002.

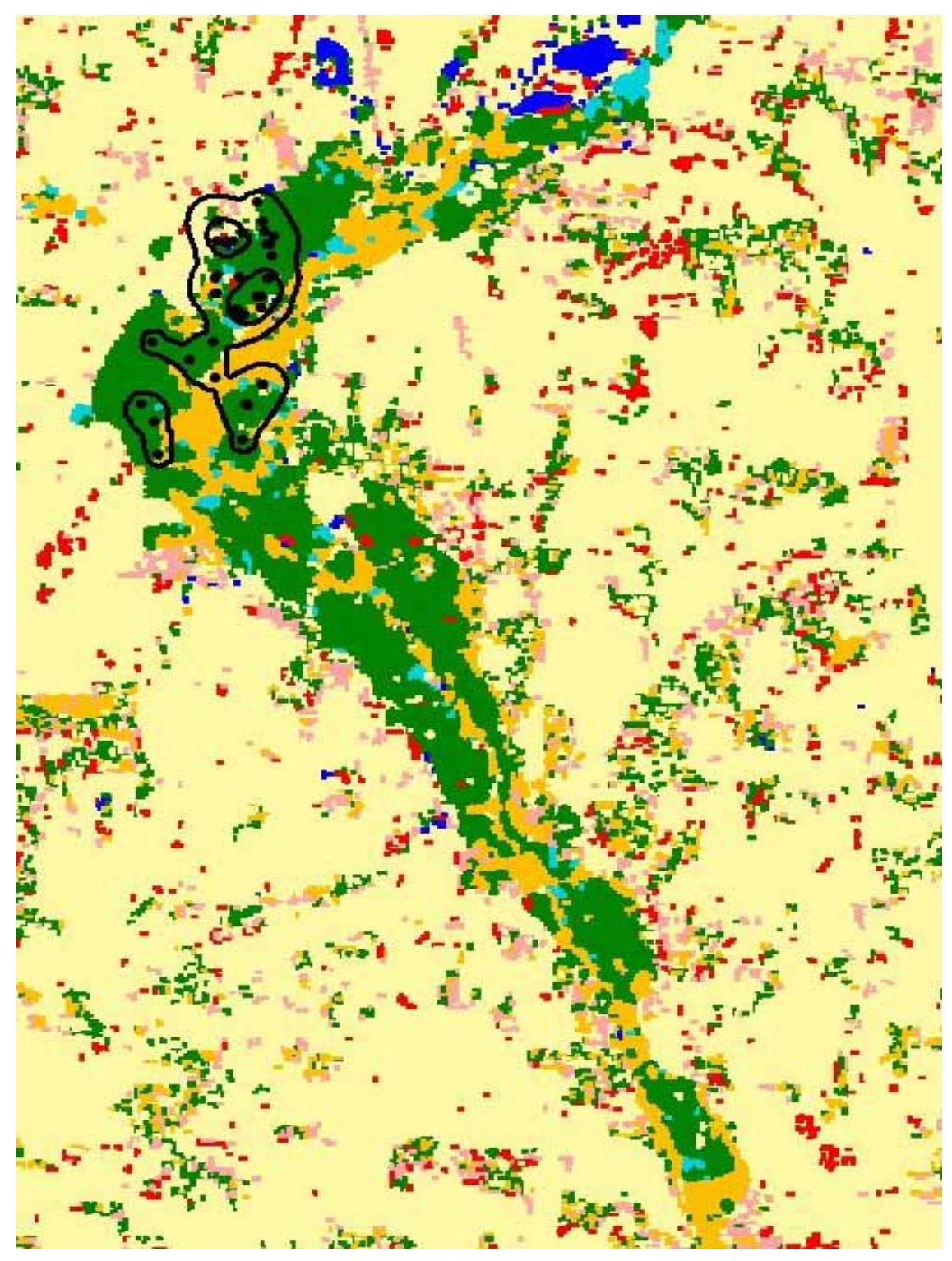


Female river otter 222 summer home range, core range, and locations in the Killbuck Watershed, Ohio during 2002.

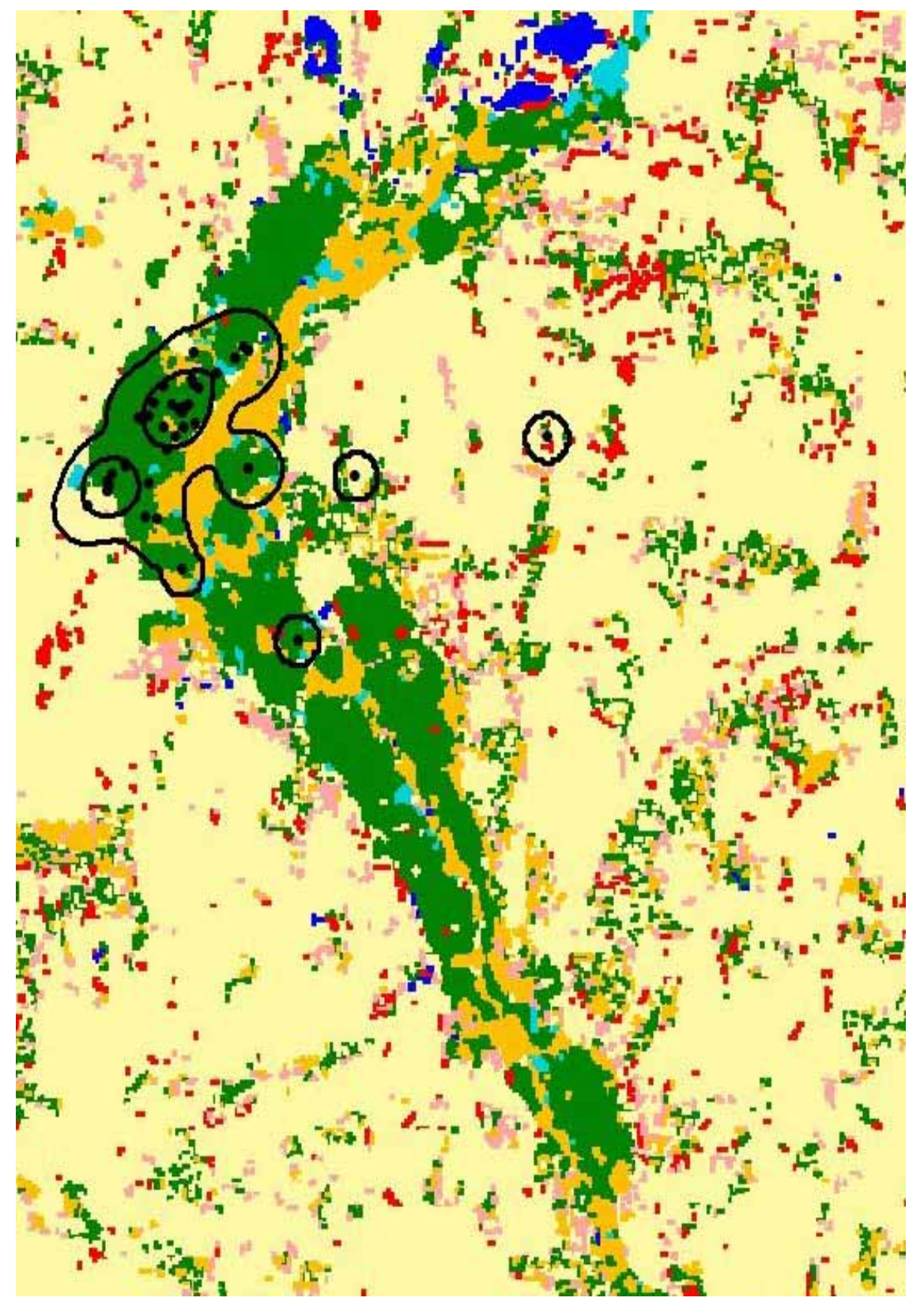


Male river otter 245 summer home range, core range, and locations in the Killbuck Watershed, Ohio during 2002.




Male river otter 284 summer home range, core range, and locations in the Killbuck Watershed, Ohio during 2002.

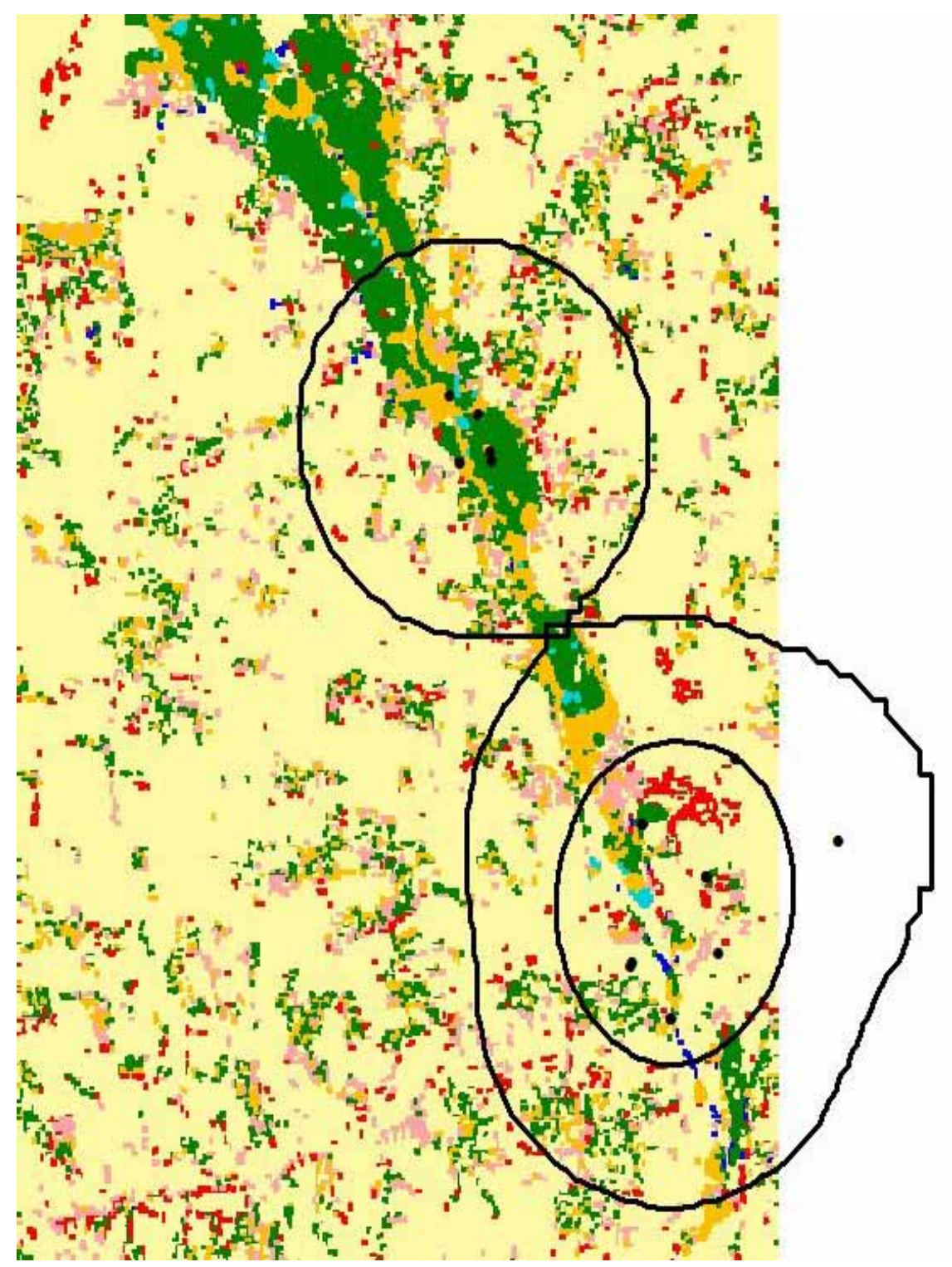


Male river otter 325 summer home range, core range, and locations in the Killbuck Watershed, Ohio during 2002.

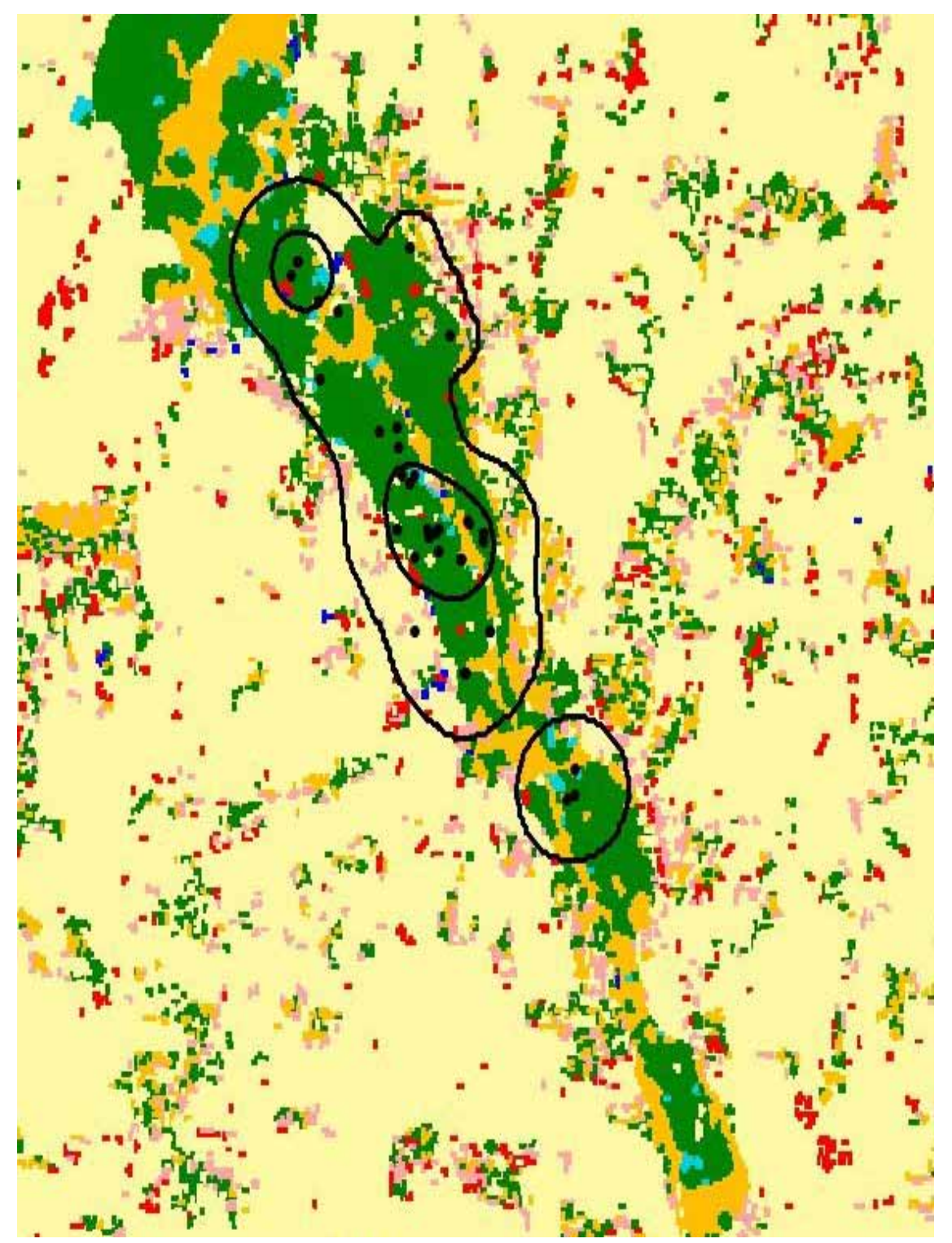


Male river otter 405 summer home range, core range, and locations in the Killbuck Watershed, Ohio during 2002.




Female river otter 064 summer home range, core range, and locations in the Killbuck Watershed, Ohio during 2003.

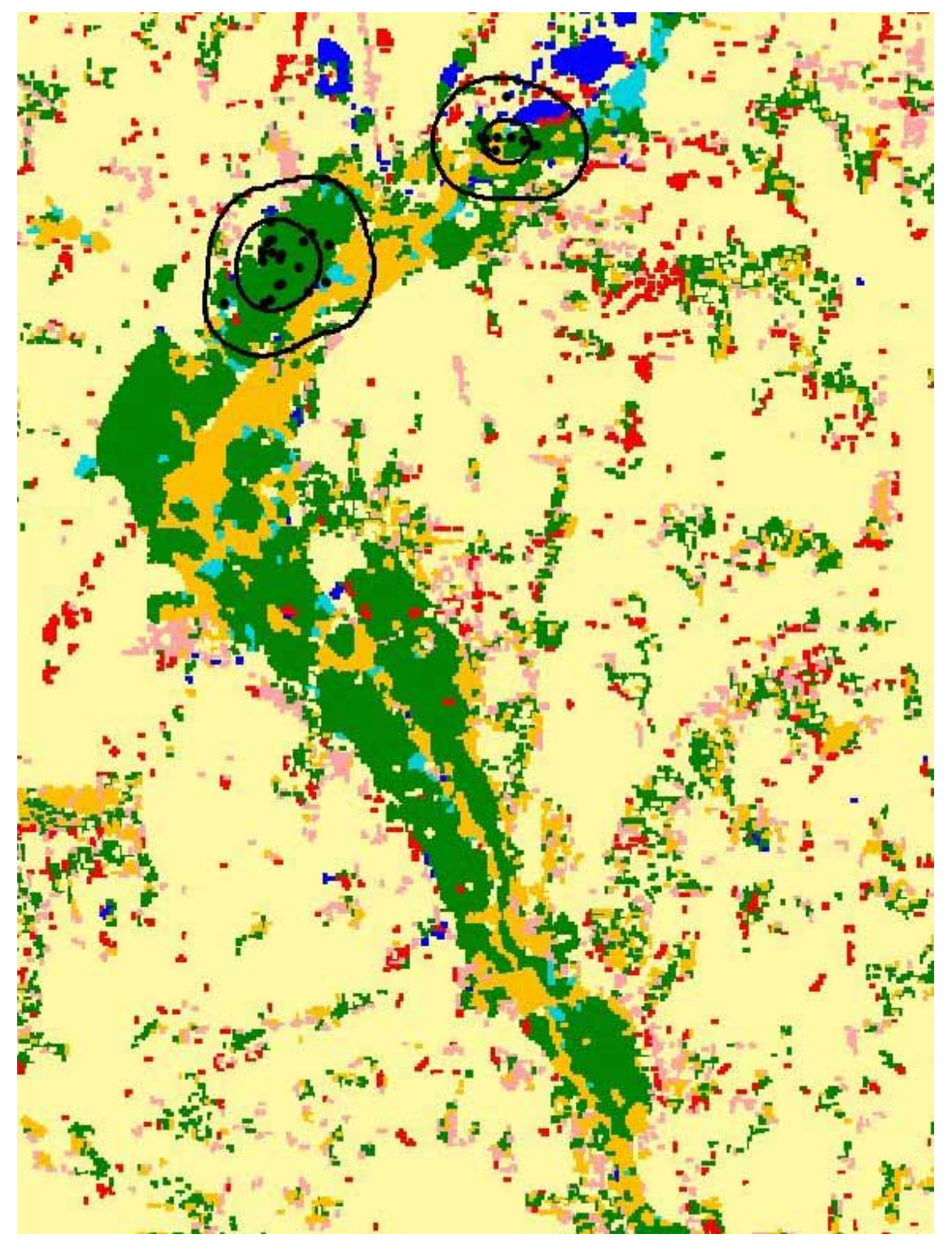


Female river otter 185 summer home range, core range, and locations in the Killbuck Watershed, Ohio during 2003.




Female river otter 222 summer home range, core range, and locations in the Killbuck Watershed, Ohio during 2003.

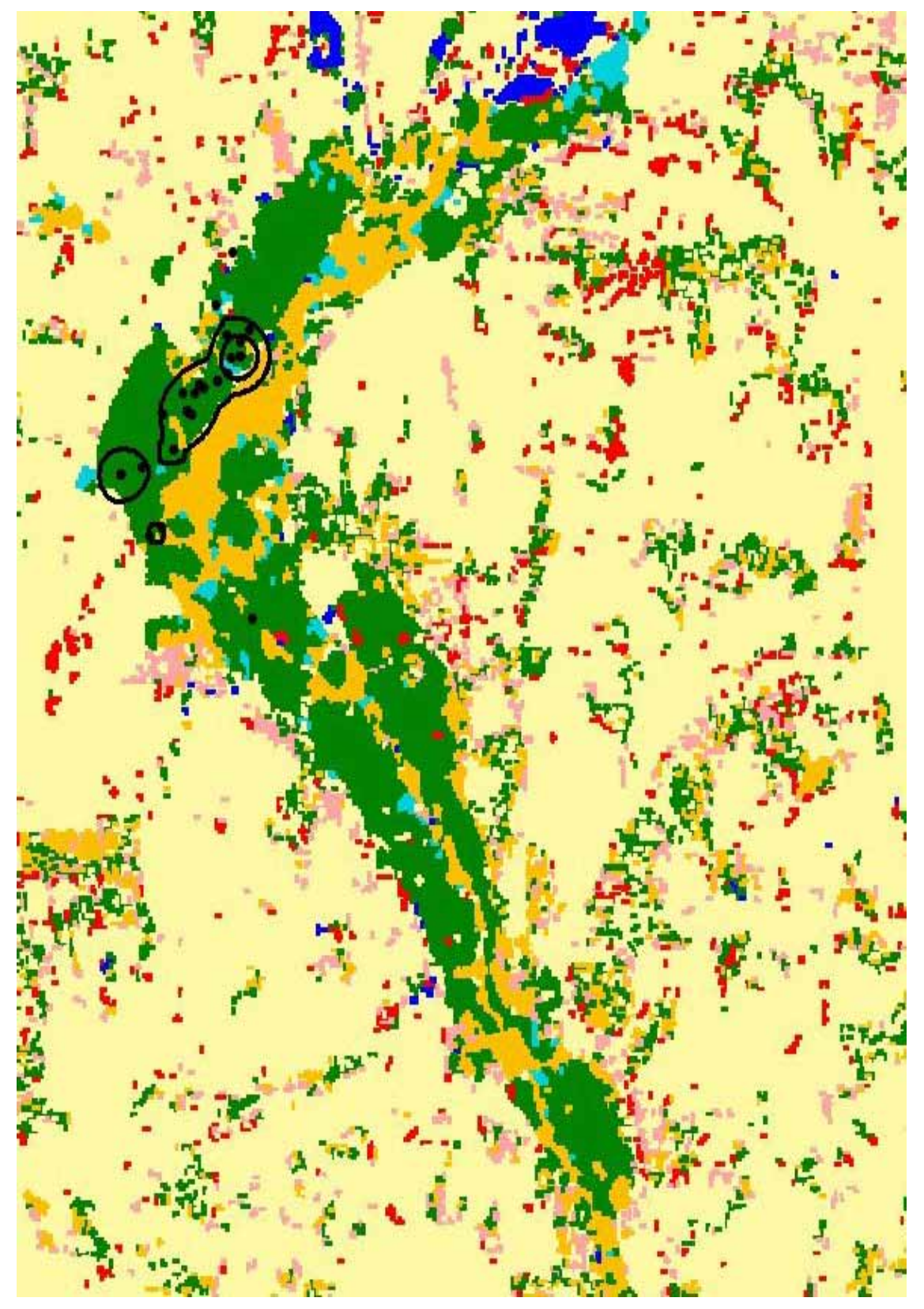


Female river otter 634 summer home range, core range, and locations in the Killbuck Watershed, Ohio during 2003.

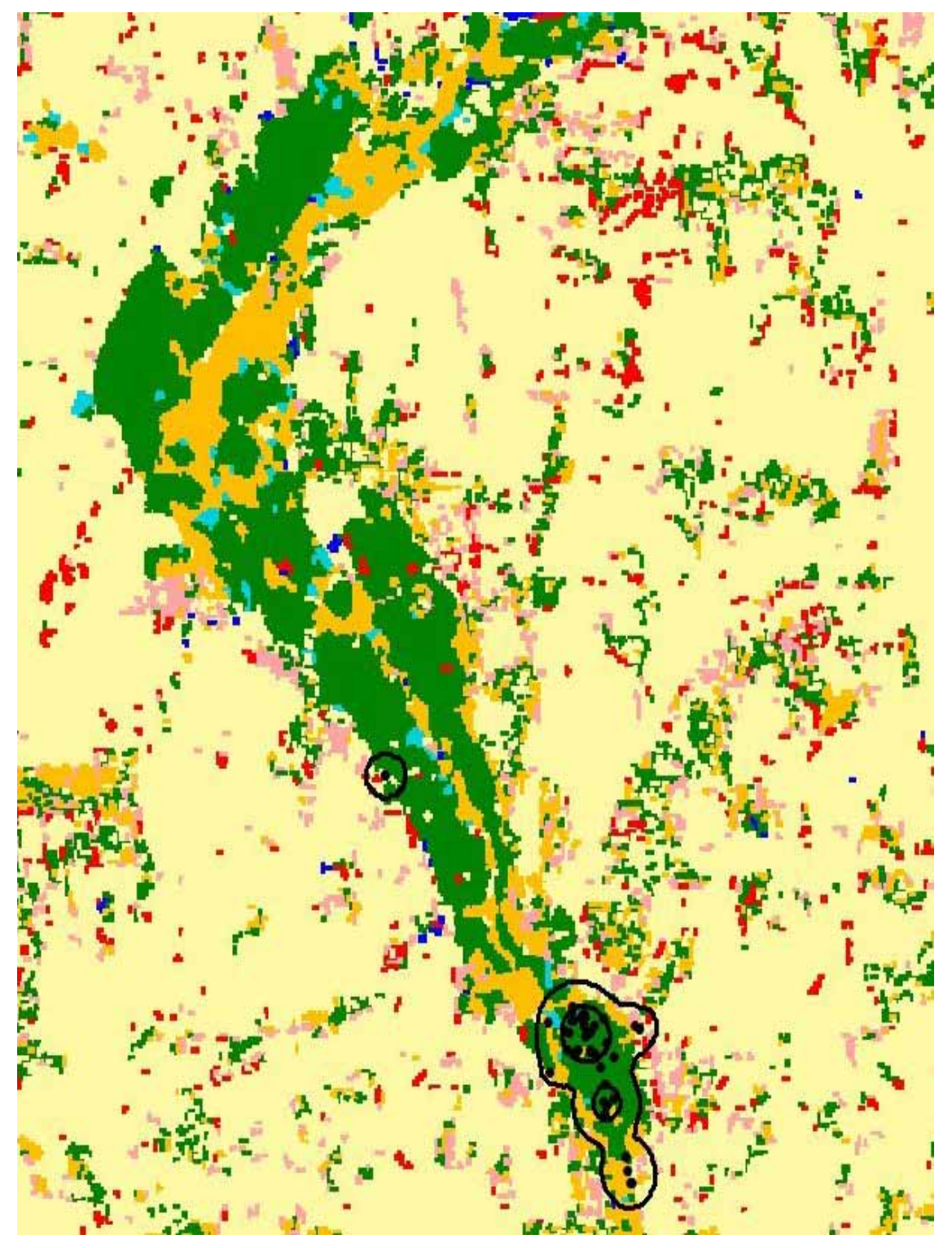


Male river otter 325 summer home range, core range, and locations in the Killbuck Watershed, Ohio during 2003.




Male river otter 405 summer home range, core range, and locations in the Killbuck Watershed, Ohio during 2003.

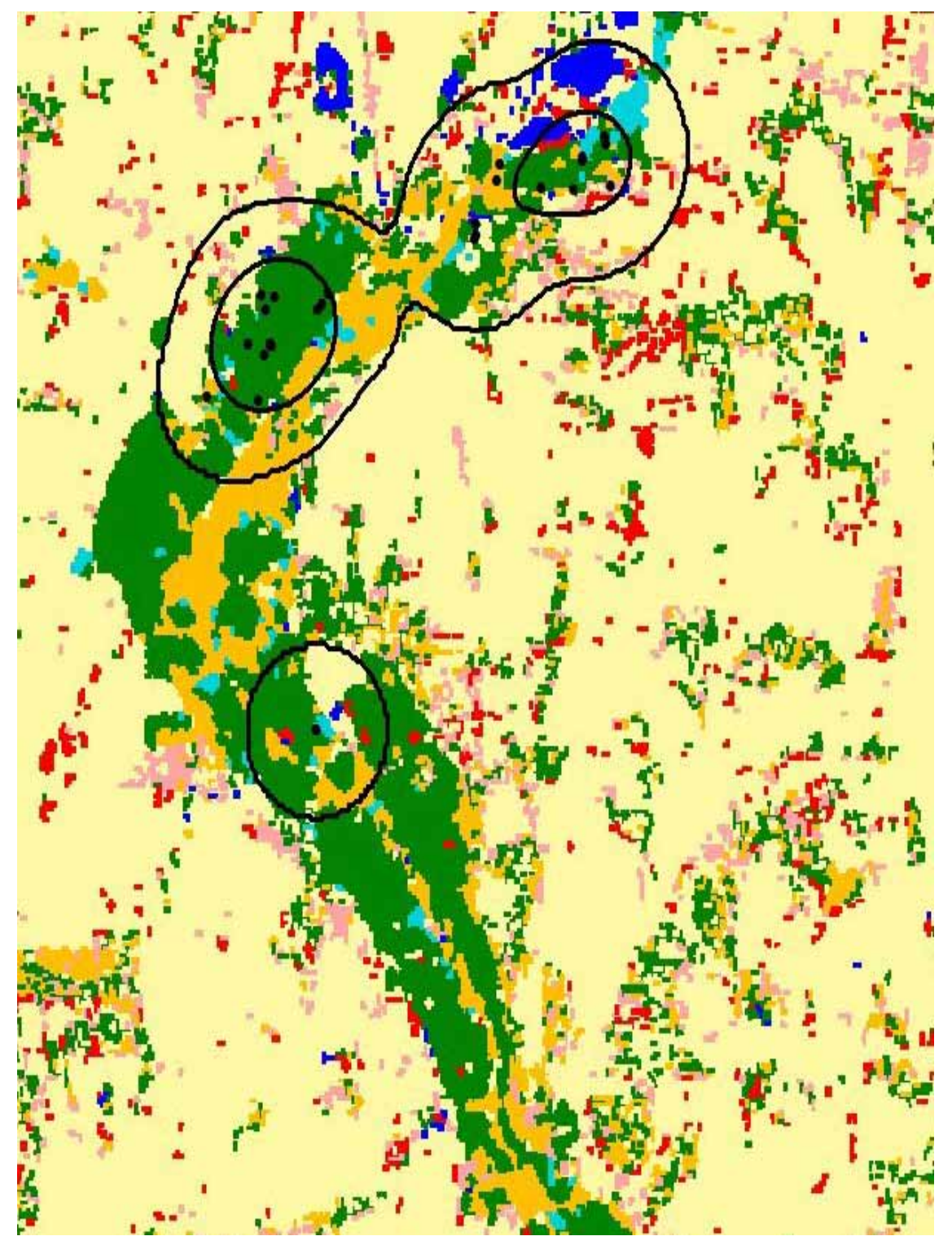


Male river otter 652 summer home range, core range, and locations in the Killbuck Watershed, Ohio during 2003.

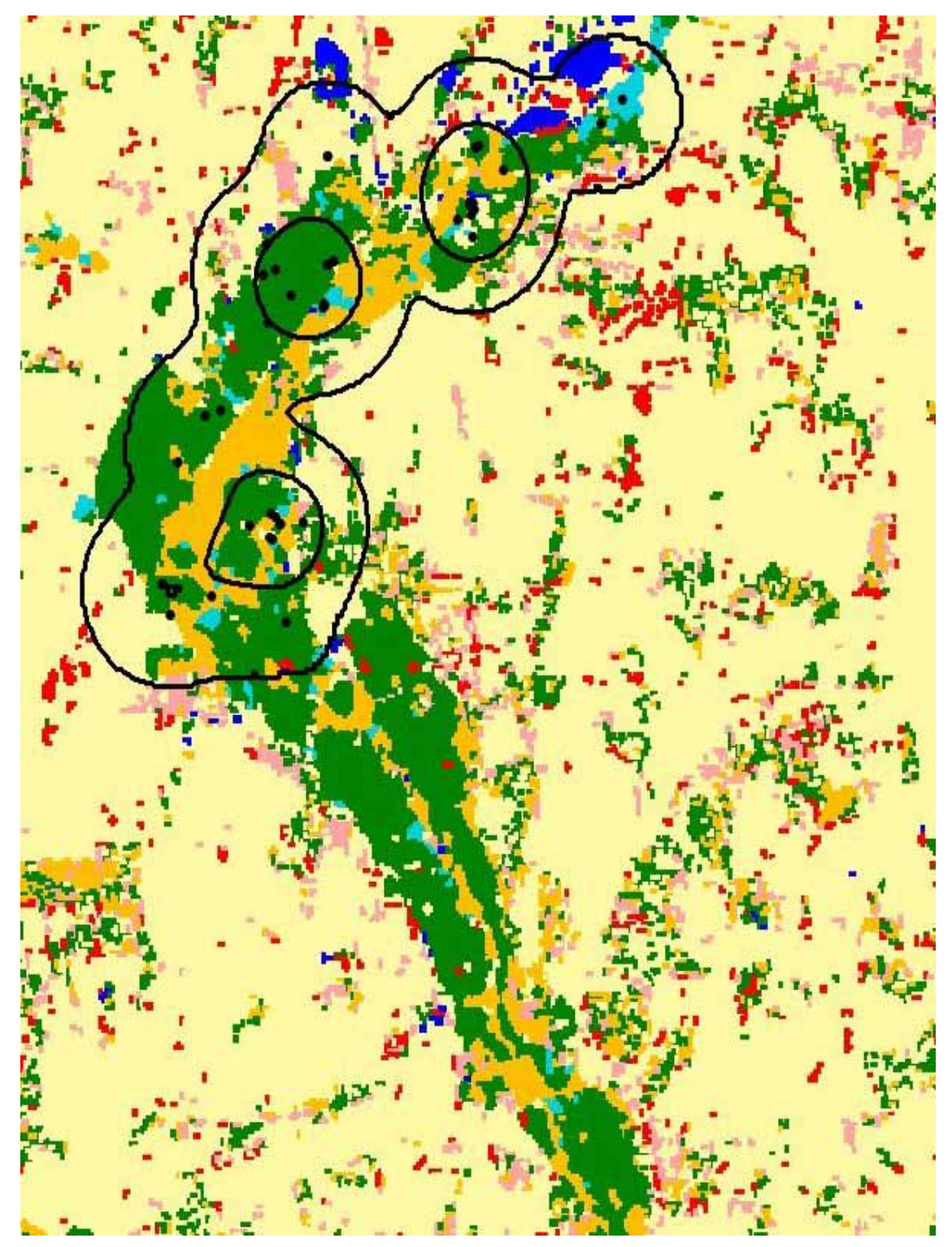


Male river otter 673 summer home range, core range, and locations in the Killbuck Watershed, Ohio during 2003.

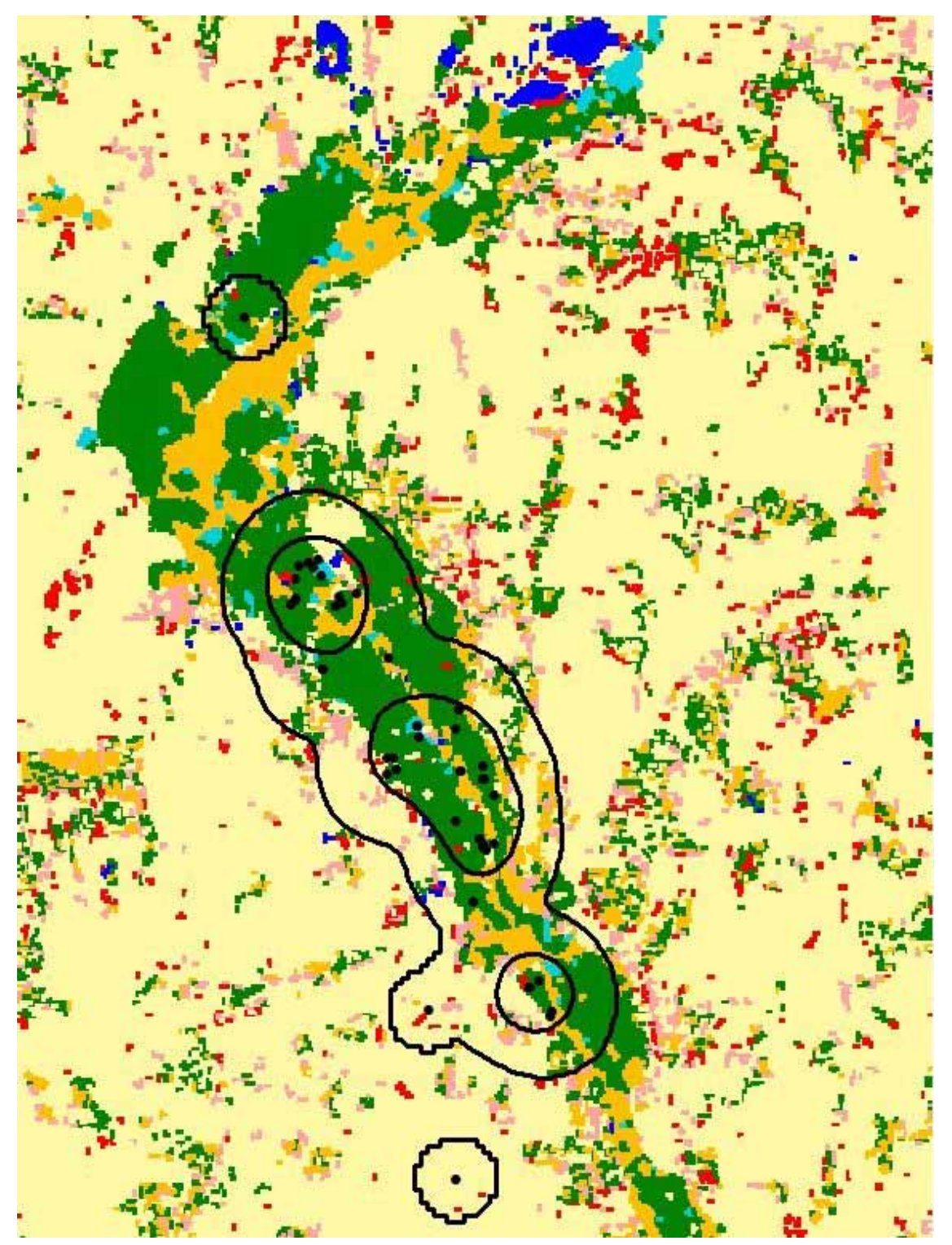


Male river otter 753 summer home range, core range, and locations in the Killbuck Watershed, Ohio during 2003.

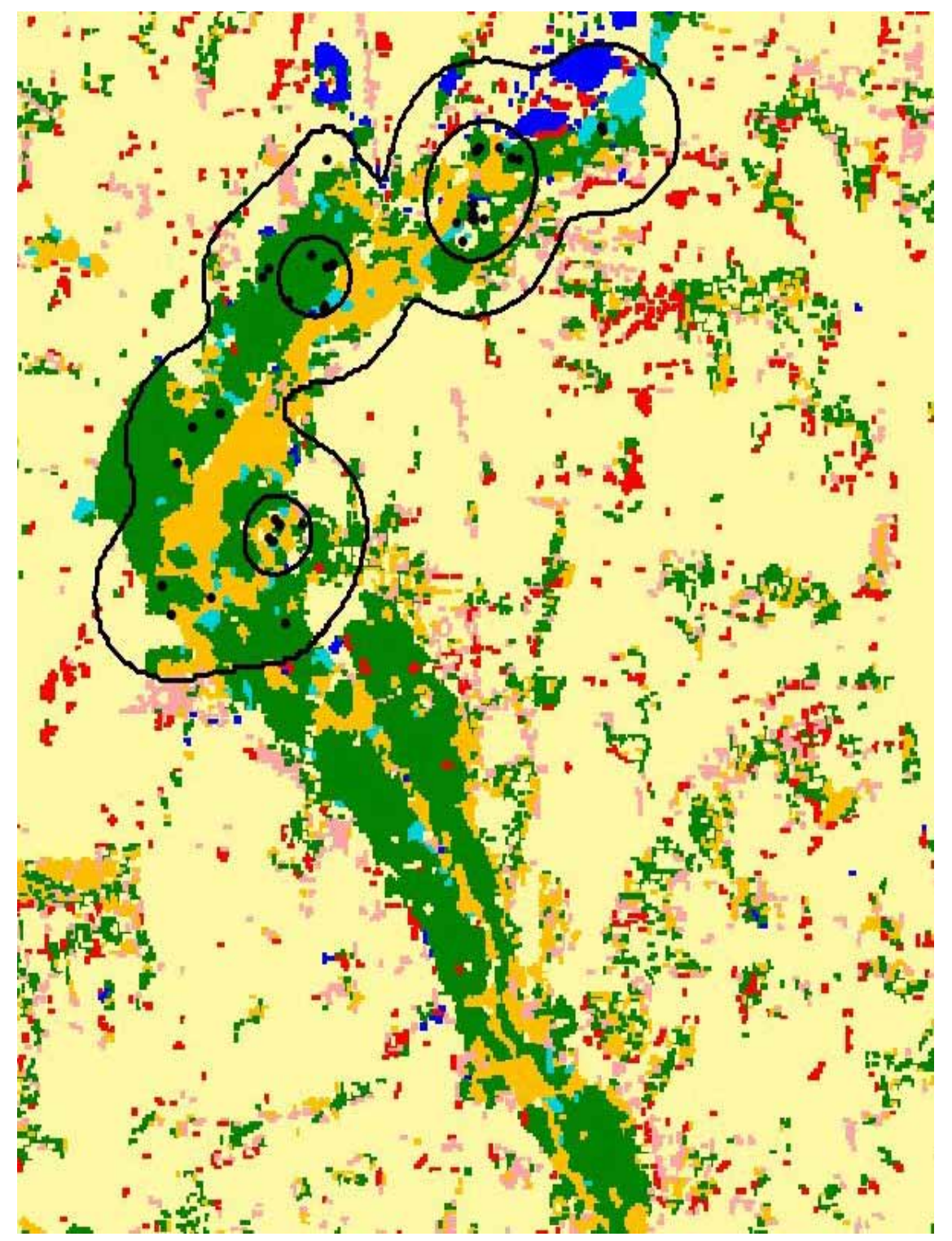


Female river otter summr home ranges in the Killbuck Watershed, Ohio during 2002.

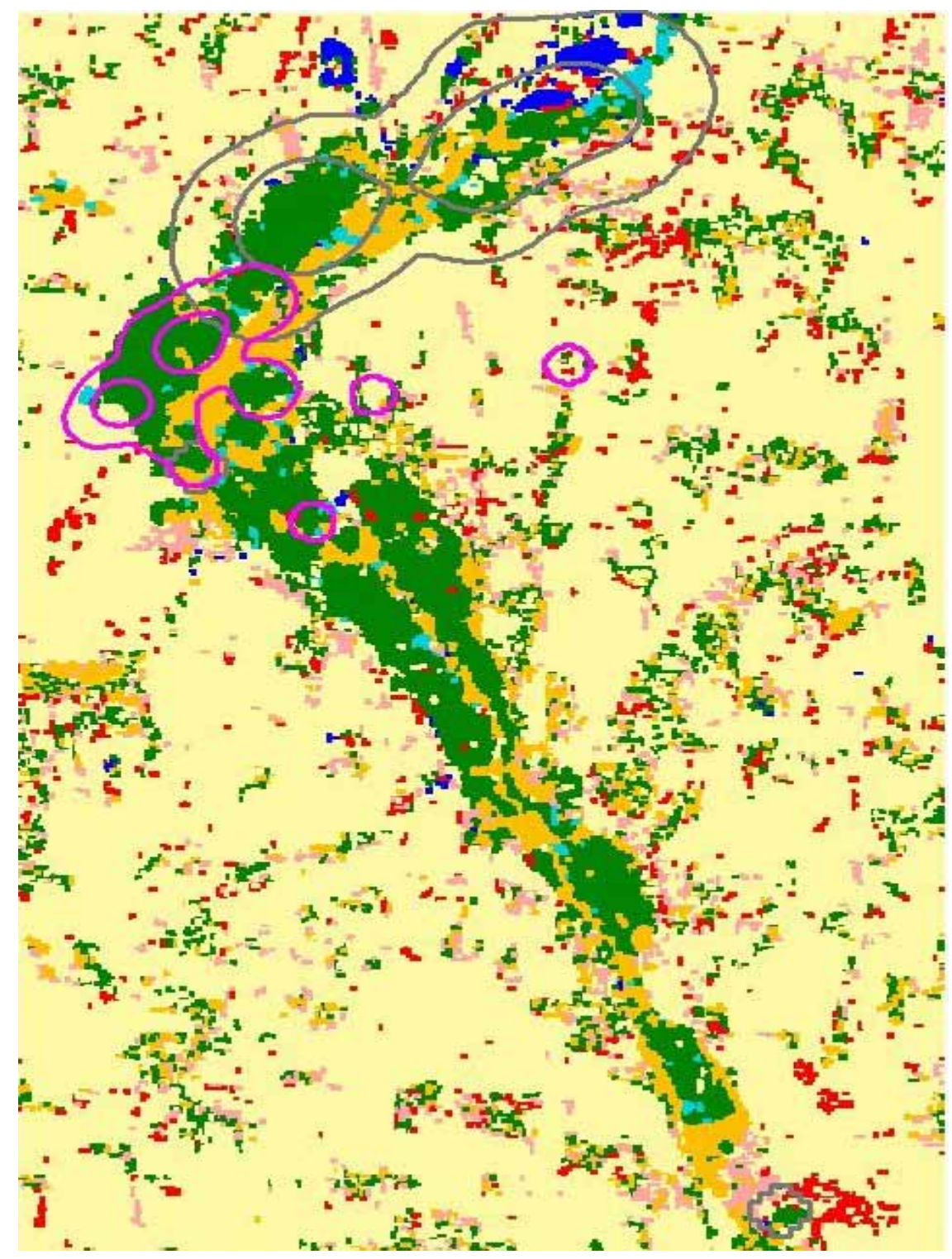


Female river otter summer home ranges in the Killbuck Watershed, Ohio during 2003.




Female river otter summer locations in the Killbuck Watershed, Ohio during 2002 and 2003.




Male river otter summer home ranges in the Killbuck Watershed, Ohio during 2002.

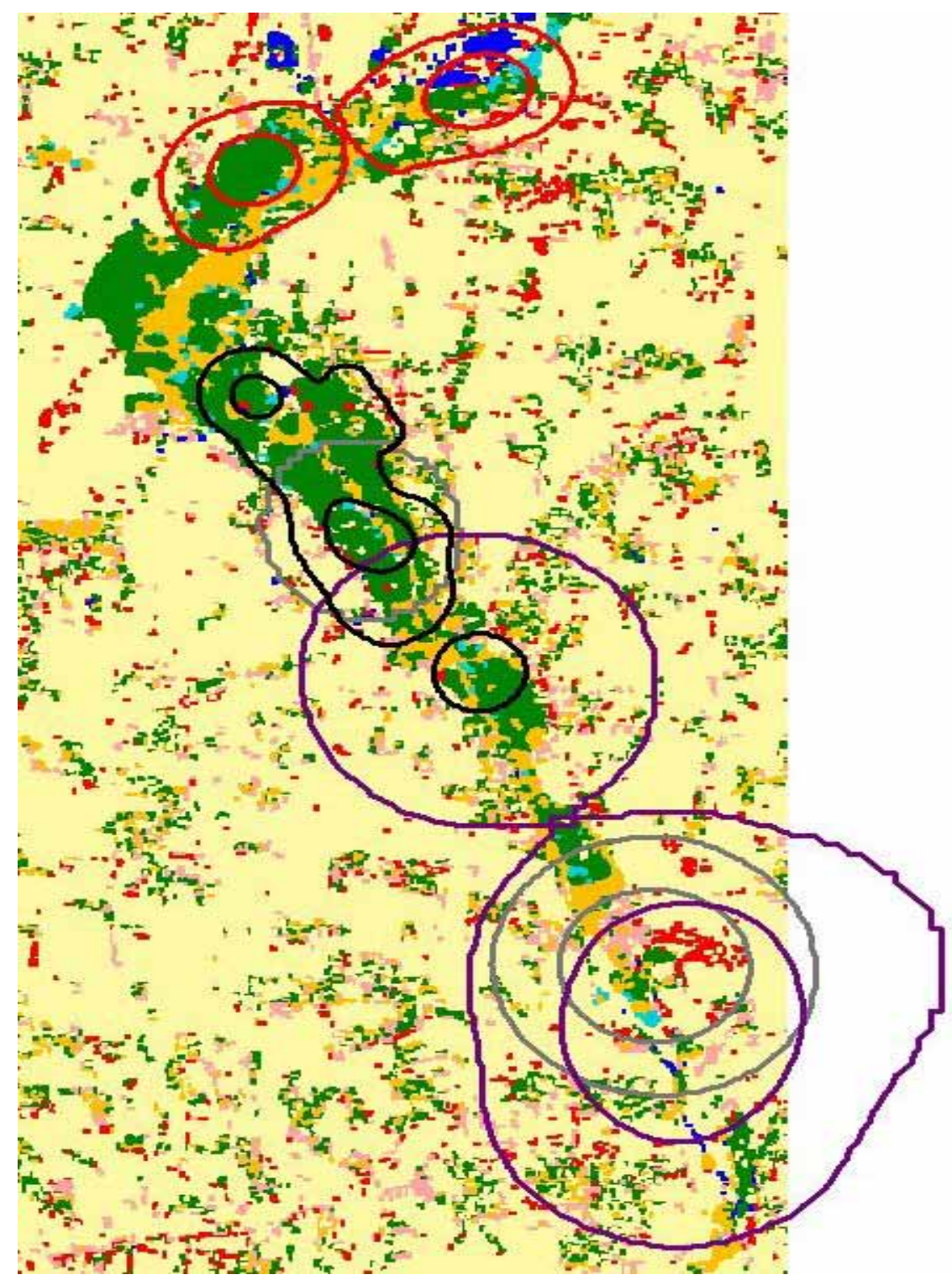


Male river otter summer home ranges in the Killbuck Watershed, Ohio during 2003.

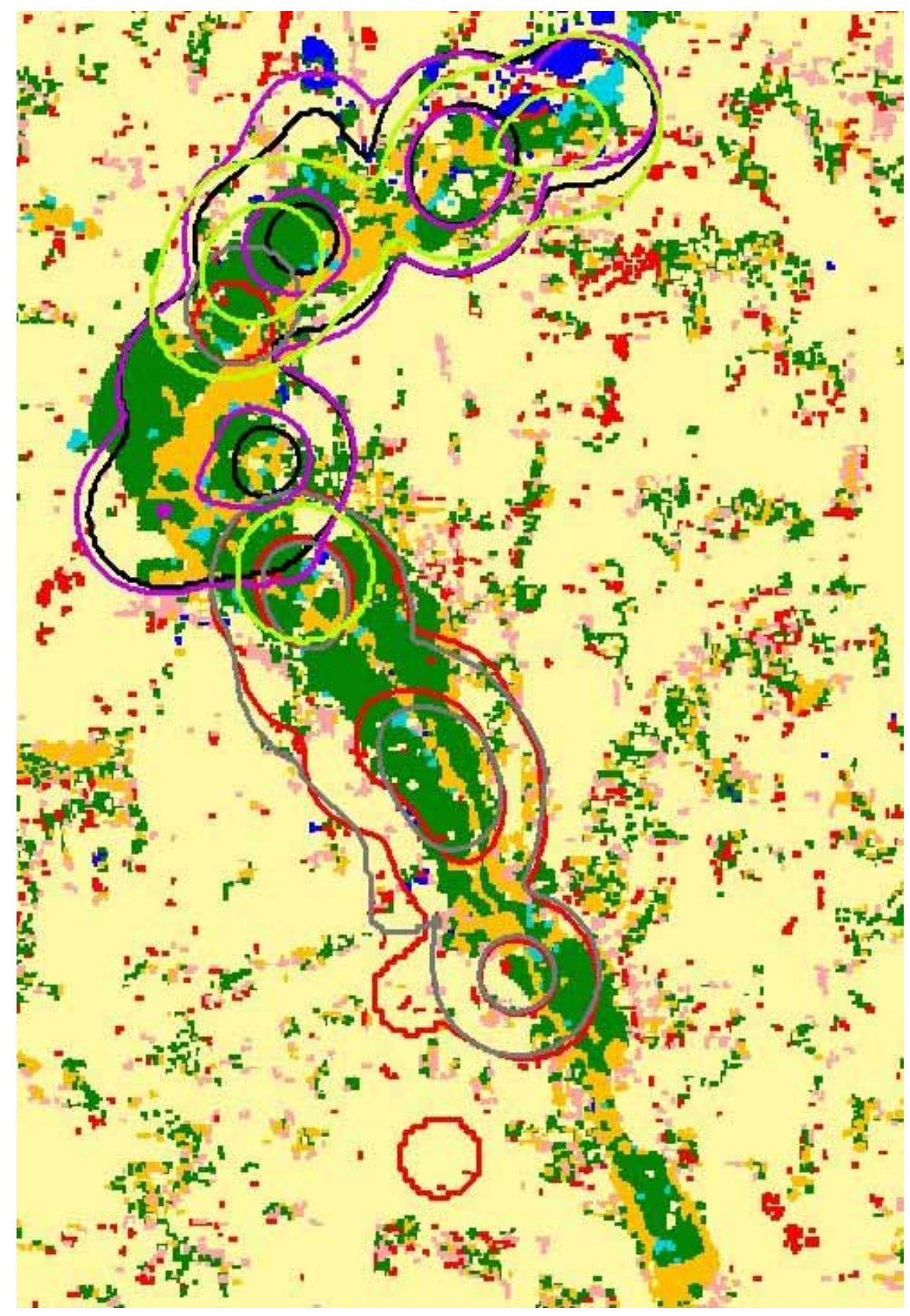


Male river otter summer locations in the Killbuck Watershed, Ohio during 2002 and 2003.

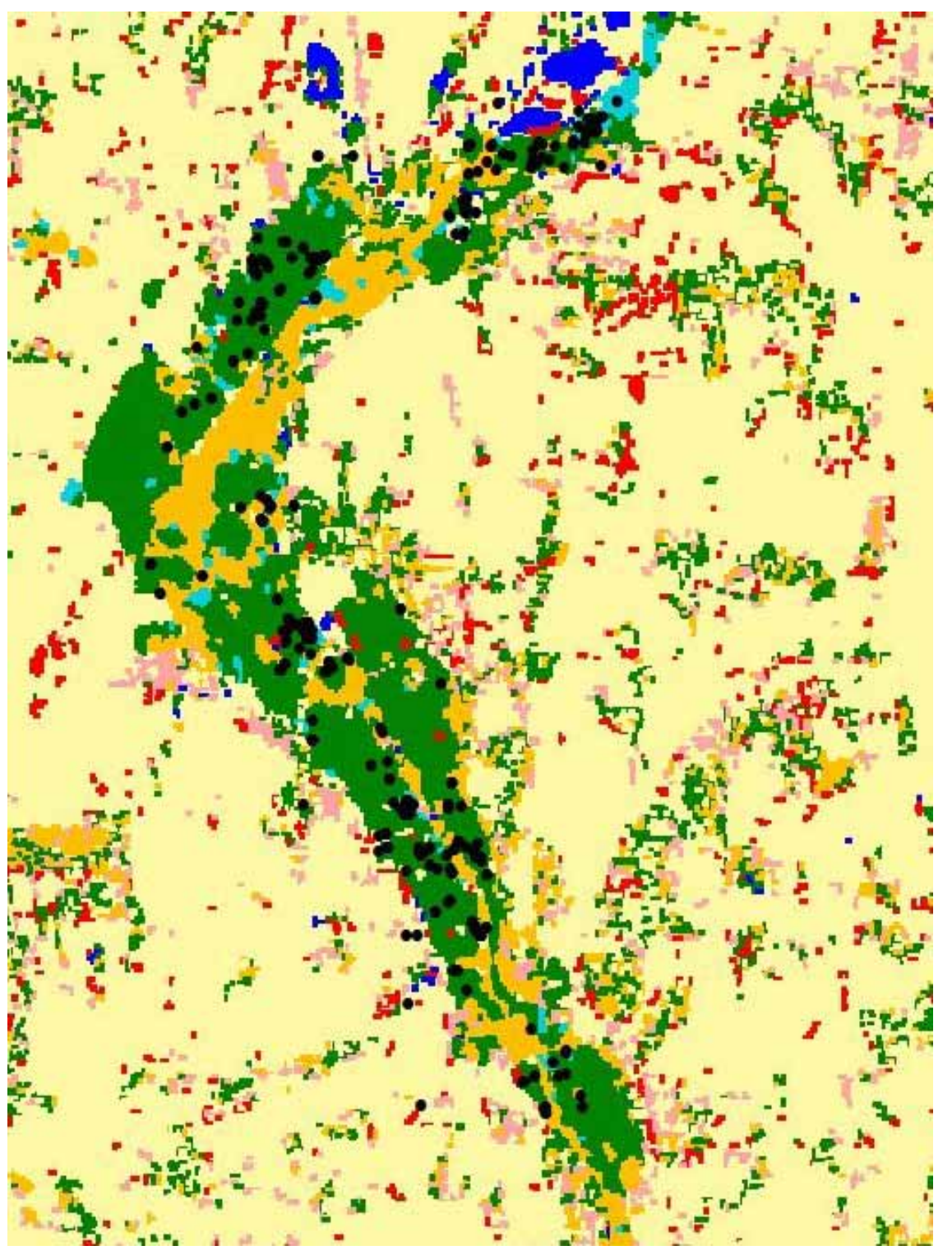


Appendix 2. Summer habitat use of river otters in the Killbuck Watershed, Ohio during 2002 and 2003.

Appendix 3. Number of locations (\% in parentheses) of radio-tagged river otters in each of 5 habitat types in the Killbuck Watershed, Ohio during 2002 and 2003.

\begin{tabular}{cccccccc}
\hline & & \multicolumn{5}{c}{ No. Locations (\% of Total Locations) } \\
\cline { 3 - 7 } Sex & Year & Open Water & Marsh & $\begin{array}{c}\text { Wet } \\
\text { Meadow }\end{array}$ & Riparian/Floodplain & Other & Totals \\
\hline Female & 2002 & $26(19)$ & $66(48)$ & $6(5)$ & $21(15)$ & $18(13)$ & 137 \\
Female & 2003 & 0 & $146(64)$ & $15(7)$ & $43(19)$ & $23(10)$ & 227 \\
Male & 2002 & $3(2)$ & $71(50)$ & $5(4)$ & $34(24)$ & $29(20)$ & 142 \\
Male & 2003 & $1(<1)$ & $167(61)$ & $23(8)$ & $55(20)$ & $29(11)$ & 275 \\
Totals & & $30(4)$ & $450(57)$ & $49(6)$ & $153(20)$ & $99(13)$ & 781 \\
\hline
\end{tabular}

